CHAYRRA CHEHADE GOMES

\author{
CARACTERIZAÇÃO MOLECULAR DOS GnRHs \\ DE Astyanax altiparanae (GARUTTI E BRITSKI, \\ 2000), SEU EFEITO IN VIVO, E SUA \\ EXPRESSÃO TEMPORAL AO LONGO DO \\ ESTÍMULO REPRODUTIVO.
}

\begin{abstract}
Tese apresentada ao
Programa de Pós-graduação em Biologia Celular e Tecidual do Instituto de Ciências Biomédicas da Universidade de São Paulo, para a obtenção do Título de Doutor em Ciências.
\end{abstract}

São Paulo 2015 
CHAYRRA CHEHADE GOMES

\section{CARACTERIZAÇÃO MOLECULAR DOS GnRHs \\ DE Astyanax altiparanae (GARUTTI E BRITSKI, 2000), SEU EFEITO IN VIVO, E SUA \\ EXPRESSÃO TEMPORAL AO LONGO DO \\ ESTÍMULO REPRODUTIVO.}

Tese apresentada ao Programa de Pós-graduação em Biologia Celular e Tecidual do Instituto de Ciências Biomédicas da Universidade de São Paulo, para a obtenção do Título de Doutor em Ciências.

Área de concentração: Biologia Celular e Tecidual

Orientadora: Profa. Dra. Maria Inês Borella

Versão original 


\section{DADOS DE CATALOGAÇÃO NA PUBLICAÇÃO (CIP) \\ Serviço de Biblioteca e Informação Biomédica do \\ Instituto de Ciências Biomédicas da Universidade de São Paulo}

reprodução não autorizada pelo autor

\section{Gomes, Chayrra Chehade.}

Caracterização molecular dos GnRHs de Astyanax altiparanae (Garutti e Britski, 2000), seu efeito in vivo, e sua expressão temporal ao longo do estimulo reprodutivo / Chayrra Chehade Gomes. -- São Paulo, 2015.

Orientador: Profa. Dra. Maria Inês Borela.

Tese (Doutorado) - Universidade de São Paulo. Instituto de Ciências Biomédicas. Departamento de Biologia Celular e do Desenvolvimento. Área de concentração: Biologia Celular e Tecidual. Linha de pesquisa: Endocrinologia da reprodução de teleósteos.

Versão do título para o inglês: Molecular characterization of $\mathrm{GnRH}$ of the Astyanax altiparanae (Garutti and Britski, 2000), its effect in vitro and its temporal expression during the reproductive stimulus.

1. Lambari 2. GnRHs 3. Esteróides 4. Gonadotropinas 5. Reprodução 6. Indução à reprodução I. Borela, Profa. Dra. Maria Inês II. Universidade de São Paulo. Instituto de Ciências Biomédicas. Programa de Pós-Graduação em Biologia Celular e Tecidual III. Título. 
UNIVERSIDADE DE SÃO PAULO

INSTITUTO DE CIÊNCIAS BIOMÉDICAS

\begin{abstract}
Candidato(a): $\quad$ Chayrra Chehade Gomes.
Título da Tese: $\quad$ Caracterização molecular dos GnRHs de Astyanax altiparanae (Garutti e Britski, 2000), seu efeito in vivo, e sua expressão temporal ao longo do estimulo reprodutivo.
\end{abstract}

Orientador(a): $\quad$ Profa. Dra. Maria Inês Borela.

A Comissão Julgadora dos trabalhos de Defesa da Tese de Doutorado, em sessão

pública realizada a

( ) Aprovado(a) , considerou

..............

( ) Reprovado(a)

\begin{tabular}{|c|c|}
\hline Examinador(a): & Assinatura: . \\
\hline & Nome: ......... \\
\hline & Instituição: . \\
\hline Examinador(a): & Assinatura: \\
\hline & Nome: ............... \\
\hline & Instituição: ........ \\
\hline Examinador(a): & Assinatura: . \\
\hline & Nome: .......... \\
\hline & Instituição: .. \\
\hline Examinador(a): & Assinatura: . \\
\hline & Nome: ..................... \\
\hline & Instituição: ......... \\
\hline Presidente: & Assinatura: \\
\hline & Nome: ......... \\
\hline & Instituição: \\
\hline
\end{tabular}


UNIVERSIDADE DE SÃO PAULO

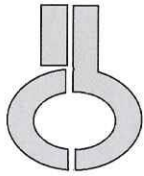

INSTITUTO DE CIÊNCIAS BIOMÉDICAS

Cidade Universitária "Armando de Salles Oliveira"

Av. Prof. Lineu Prestes, 2415 - CEP. 05508-000 São Paulo, SP Brasil

Telefone :(55) (011) 3091.7733 - e-mail: cep@icb.usp.br

\section{Certificado}

Certificamos que o protocolo registrado sob $n^{\circ} 017$ nas fls. 99 do livro 02 para uso de animais em experimentação, sob a responsabilidade do Prof(a) $\operatorname{Dr}(a)$ ) Maria Inês Borella , Coordenador(a) da Linha de pesquisa "Clonagem do gnrh de Astyanaxaltiparanae (Garutti e Britski, 2000) e seu efeito in vivo" do qual participam o(s) alunos Chayrra Chehade Gomes e a pesquisadora Silvana Auxiliadora Bordin Silva, está de acordo com os Princípios Éticos de Experimentação Animal adotado pela Sociedade Brasileira de Ciência de Animais de Laboratório (SBCAL) e foi aprovado pela COMISSÃO DE ÉTICA NO USO DE ANIMAIS (CEUA) em 15.02.2011, com validade de 3 anos.

São Paulo, 17 de fevereiro de 2011.

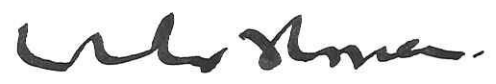

Prof.Dr.WOTHAN TAVARES DE LIMA Coordenador CEUA - ICB/USP

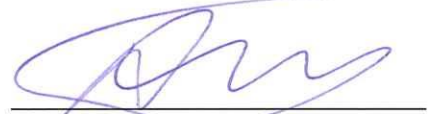

Prof. Dr. ARIEL MARIANO SILBER Secretário CEUA - ICB/USP 


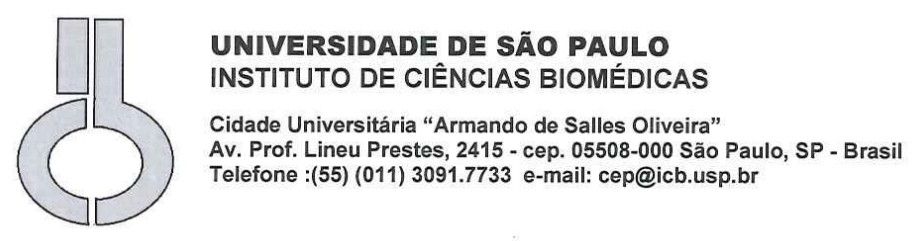

Of.CEUA. 006.14

São Paulo, 13 de março de 2014.

REF.: Protocolo no 017/11.

"Clonagem do gnrh de Astyanaxaltiparanae (Garutti e Britski, 2000) e seu efeito in vivo"

Prezada Professora,

Informo que a sua licença para uso de animais em experimentação, constante no protocolo em epígrafe, foi prorrogada até 15.02.2017.

Reitero que havendo alteração de metodologia e inserção de novos alunos ao projeto de pesquisa vinculado à referida licença a CEUA/ICB deverá ser informada.

Cordialmente,

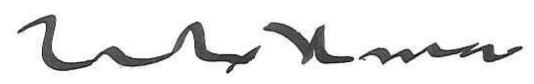

Prof. Dr. WOTHAN TAVARES DE LIMA

Coordenador - CEUA-ICB/ /USP

Ilma.Sra.

Profa- Dra. Maria Inês Borella

Departamento de Biologia Celular e do Desenvolvimento

Instituto de Ciências Biomédicas - USP 


\section{AGRADECIMENTOS}

Essa é parte da tese, para mim, mais difícil de escrever, mesmo sendo em uma linguagem mais informal. No entanto, é a seção mais especial, onde demonstro que sem a ajuda, carinho, dedicação, compreensão, entre outros muitos adjetivos das pessoas aqui citadas, esse trabalho não teria acontecido e eu não teria convivido e feitos amigos tão especiais que com certeza contribuíram muito na minha formação tanto profissional como também pessoal.

Dessa forma agradeço:

A Deus e a todos os "anjos" pela orientação durante essa caminhada em busca da minha formação e do conhecimento.

A duas das pessoas mais importantes na minha vida, os meus pais, Paulo Roberto Gomes e Sálua Chehade Gomes, que mesmo sabendo das dificuldades de se fazer uma pós-graduação longe de casa, dificuldades essas conhecidas já no período do mestrado, principalmente em relação aos gastos, eles me apoiaram fielmente depositando em mim toda a confiança. Além disso, sou mais do que agradecida a essas duas pessoas tão especiais por toda a educação e formação que me deram sempre com muito carinho e amor.

Ao meu marido, Wellington Silva Fernandez, que teve sempre muita paciência e compreensão principalmente nos momentos mais estressantes, que, diga-se de passagem, são muitos durante a pós-graduação, sempre me acalmando e me dando forças para seguir em frente, além disso, colocou a "mão na massa" participando dos experimentos mais difíceis do trabalho, ficando 36 horas sem dormir e trabalhando muito ao meu lado (neste período era ainda só meu namorado). Diante de tudo, só tenho a dizer muito obrigada meu amor por tudo. 
Aos meus irmãos, Paula Chehade Gomes e Paulo Roberto Gomes Júnior, que são muito amorosos e a quem eu amo muito, sinto como se nós três fizéssemos parte de um só ser, com relação ao período retratado nessa seção, sempre estavam interessados no meu trabalho, sendo que a Paula acompanhou diariamente as sensações vividas por mim durante todo esse período, vindo morar em São Paulo comigo desse o início do doutorado, muito obrigada meus irmãos.

A Maria Inês Borella, que durante esses 8 anos juntas se tornou não só minha orientadora, mas a minha segunda mãe e uma grande amiga, serei eternamente grata, por todos os ensinamentos, a confiança em mim depositada e todos os momentos vividos que sempre foram muito especiais, esta etapa chegou ao fim, mas tenho certeza que nosso relacionamento não acaba por aqui, quero ter para sempre a $M$. Inês por perto ocupando agora não mais o cargo de orientadora, mas todos os outros citados acima, a qual ela também sempre exerceu muito bem.

Agradeço também a todos os meus familiares que sempre estiveram por perto me apoiando.

Ao Fabiano Gonçalves Costa, que foi um grande professor e orientador durante a época da graduação o qual contribuiu muito na minha formação e que me guiou até a pós-graduação, sendo hoje um grande amigo a quem tenho muito a agradecer e que quero muito bem.

A todos os alunos do laboratório, em que alguns se tornaram grandes amigos, e contribuíram muito com o trabalho em diversos aspectos desde ajuda em bancada, discussões científicas, com a paciência entre vários outros pontos, sendo eles Lázaro W. O. de Jesus, Gisele C. M Dias, Giovana S. Branco, Marília P. Camargo, Mônica Cassel, Telma A. Monezi, Gabriel M. S. Neto, Rejane M. Funes e o Mateus $C$. Adolfi que não está mais fisicamente no laboratório, mas que faz parte do "grande cardume". 
Ao técnico e amigo, Cruz Alberto Mendoza Rigonati, por toda a ajuda, paciência, pelas conversas e cafés, muito obrigada.

As técnicas e também amigas, Emília Ribeiro, Rosangela Farias e Julieta Scialfa por toda a ajuda dedicada.

A minha co-orientadora Silvana A. Bordin, por toda a contribuição e orientação durante todo o período.

A Fernanda Gaspar do Amaral, uma pessoa muito especial e iluminada, que esteve comigo desde o início e quem eu serei imensamente grata, dedicou muito do seu tempo em me ajudar e me ensinar algumas das técnicas empregadas neste trabalho, exercendo a função como uma co-orientadora, juntamente com a Silvana, e que hoje se tornou uma grande amiga.

Ao professor José Cipolla Neto, pela disponibilidade do laboratório e pela ajuda intelectual na interpretação dos resultados. Agradeço também a todos os seus alunos (Carol, Jéssica, Ariane, Lívia, Sinésio, Rosana e Fernanda), por toda ajuda e também pela compreensão com a minha "invasão" do laboratório.

A professora Estela Bevilacqua, também por me dar espaço de trabalhar em seu laboratório e a todos seus alunos, mas especialmente a Sara M. Z. Gomes, Aline Lorenzon e o Rodrigo B. Weingrill, por toda a ajuda e amizade.

A professora Glaucia M. Machado-Santelli, por disponibilizar o uso de alguns equipamentos de seu laboratório, e aos seus alunos que sempre foram muito prestativos.

Ao professor Fabio Siviero, sempre disposto a ajudar, e que contribuiu muito com o meu trabalho na parte de bioinformática e em técnicas como a do 
Genome Walker, na tentativa de conseguirmos caracterizar os GnRHs que por fim deu tudo certo, além das contribuições por ele dadas na minha banca de qualificação.

A professora Renata Guimarães Moreira, por toda a dedicação e auxilio durante todo o meu doutorado, principalmente na etapa final com as análises de ELISA, sempre muito prestativa e atenciosa, uma pessoa incrível e muito admirada. Gostaria de agradecer a todos seus alunos, principalmente a Gabi que me ajudou muito durante o experimento de injeção e também nas análises de ELISA, mas também a Roberta, ao Andreone, a Walquiria e ao Carlos (Jabuti).

Ao professor Claudio Alvarenga e Professor Ruy Jaeger por toda a contribuição dada durante a qualificação, assim como o professor Fabio que foi mencionado acima.

A Patrícia Gomes, por toda a ajuda e amizade durante todo o período.

Aos funcionários da estação de piscicultura da companhia energética do estado de São Paulo (CESP) pelos peixes doados para a execução do trabalho, entre eles o Danilo Caneppele, sempre disposto em ajudar.

Ao Rafael Henrique Nobrega, Sérgio Ricardo Batlouni e Elizabeth Romagosa, por serem pesquisadores e professores exemplares e sempre que tivemos a oportunidade de nos encontrarmos contribuições surgiram para um melhor andamento do projeto.

A todos os funcionários e docentes do departamento e do Instituto de Ciências Biomédicas I, os quais com muitos o contato foi diário, fazendo este convívio com toda a certeza diferença no final desses anos e contribuíram muito para minha formação pessoal e profissional. 
As secretárias do departamento, Regina, Eloise, Ana Lucia e Paulo, sempre muito atenciosos e prestativos.

Aos funcionários da biblioteca sempre dispostos a ajudar.

A FAPESP, a minha bolsa e ao financiamento do projeto de pesquisa.

De forma geral gostaria de agradecer a todos aqueles que passaram na minha vida durante esse tempo que de uma forma ou de outra tiveram sua contribuição na minha formação como pessoa e também profissional, espero não ter esquecido muita gente, já que para que eu conseguisse realizar esse trabalho a ajuda de todos foi essencial, por isso de antemão peço desculpas a quem não foi citado. 


\section{RESUMO}

GOMES, C. C. Caracterização molecular dos GnRHs de Astyanax altiparanae (Garutti e Britski, 2000), seu efeito in vivo, e sua expressão temporal ao longo do estímulo reprodutivo. 2015. $145 \mathrm{f}$. Tese (Doutorado em Biologia Celular e Tecidual) - Instituto de Ciências Biomédicas da Universidade de São Paulo; São Paulo, 2015.

O estudo da reprodução em peixes vem adquirindo importância nos últimos anos por representar possibilidades de intervenção no processo reprodutivo, especialmente em prol de espécies ameaçadas de extinção. Durante este processo, neurônios hipotalâmicos sintetizam e liberam o hormônio liberador de gonadotropina $(\mathrm{GnRH})$ que estimula as células hipofisárias a liberarem $\mathrm{FSH}$ e $\mathrm{LH}$, os quais promovem a maturação gonadal. Portanto, as alterações morfológicas gonadais são resultantes da ação endócrina do eixo reprodutivo, sendo o $\mathrm{GnRH}$ a principal molécula a disparar o controle deste eixo. Desta forma, o aprofundamento do conhecimento sobre o $\mathrm{GnRH}$, assim como sobre as mudanças morfológicas gonadais na desova, pode contribuir para a eficácia da reprodução. Diante disso, pretende-se, no presente trabalho, tendo o Astyanax altiparanae como modelo de estudo, realizar a caracterização molecular dos tipos de $\mathrm{GnRH}$, analisar as alterações morfológicas gonadais durante o estímulo reprodutivo, além de avaliar a função dos GnRHs por meio da injeção dos mesmos. Como resultado, foi obtida a sequência completa do cDNA do preproGnRH2 de $A$. altiparanae com $612 \mathrm{pb}$, assim como do preproGnRH3 com 407 pb. Para a indução à reprodução com redução do nível da água, foi visto que a eliminação dos gametas ocorreu em fêmeas às 20 horas pós-estímulo, enquanto em machos foi às 16 horas pósestímulo; além disso, as fêmeas tiveram aumento da expressão do mRNA GnRH3 às 8 horas pós-estímulo, e os machos tiveram aumento da expressão do mRNA GnRH2 no momento do estímulo. Com relação ao efeito dos $\mathrm{GnRHs,} \mathrm{foi}$ observado que todos os $\mathrm{GnRH}$ s estimularam a expressão do mRNA $\beta \mathrm{LH}$, mas não do mRNA $\beta F S H$; no entanto, só o $\mathrm{GnRH} 2$ foi capaz de aumentar a síntese do hormônio indutor da maturação (MIS) e ocasionar a liberação de gametas. Dessa forma, concluímos que as sequências dos cDNAs dos preproGnRHs de $A$. altiparanae apresentaram alta conservação, porém com uma alteração do aminoácido presente na posição 8 do decapeptídeo GnRH3. Além disso, foi visto que a indução à reprodução por redução do nível da água mostrou-se eficaz, e que em cativeiro o Astyanax altiparanae apresenta um desenvolvimento assincrônico com desova parcelada durante o período reprodutivo. Ainda, com as análises dos animais submetidos ao estímulo reprodutivo, sugerimos que 0 $\mathrm{GnRH} 2$ provavelmente exerce uma função ligada ao comportamento reprodutivo, e o GnRH3 possivelmente seja a forma hipofisiotrópica em Astyanax altiparanae. Por fim, quando analisamos os efeitos dos GnRHs in vivo, somente o GnRH2 se mostrou capaz de desencadear toda a cascata hormonal necessária, levando o animal à desova.

Palavras chaves: Lambari. GnRH. Esteróides. Gonadotropinas. Reprodução. Indução à reprodução. 


\section{ABSTRACT}

GOMES, C. C. Molecular characterization of GnRH of the Astyanax altiparanae (Garutti and Britski, 2000), its effect in vivo, and its temporal expression during the reproductive stimulus. 2015. $145 \mathrm{p}$. Ph. D. Thesis (Cell Biology and Tissue) - Instituto de Ciências Biomédicas da Universidade de São Paulo; São Paulo, 2015.

The study on reproduction in fish has been acquired great importance in last years, mainly for the benefit of threatened species. During the reproductive process, the hypothalamic neurons synthesize and release $\mathrm{GnRH}$ that stimulates the pituitary cells to release $\mathrm{FSH}$ and $\mathrm{LH}$, which, in turn, promote the gonadal maturation. In fact, the morphological changes in gonads are the result of the endocrine action of the reproductive axis, in which the $\mathrm{GnRH}$ is the key molecule to starting the reproductive axis control. Thus, the knowledge about the $\mathrm{GnRH}$, as well as about the gonadal morphological changes in the spawning might contribute to effectiveness of reproduction. Therefore, in this work, with Astyanax altiparanae as a model, we made the molecular characterization of the GnRHs, and we analyzed the gonadal morphological changes during the reproductive stimulus. In addition, we evaluated the role of injected GnRHs in vivo. As results, we obtain the cDNA complete sequence of preproGnRH2 (612 bp) and preproGnRH3 (407 bp) of $A$. altiparanae. Regarding the induction of reproduction by water level drawdown, the released of gametes occurred at 20 hours after stimulus in female and at 16 hours after stimulus in males, the mRNA expression of $\mathrm{GnRH} 3$ increased at 8 hours after stimulus in female and the mRNA expression of $\mathrm{GnRH} 2$ increased at 0 hours in males. Regarding the effects of injected $\mathrm{GnRH}$, all of them stimulated the $\beta \mathrm{LH}$ but not $\beta \mathrm{FSH}$ mRNA expression, and only the $\mathrm{GnRH} 2$ was able to rise the MIS and stimulate the released of gametes. We conclude that the cDNAs sequences of preproGnRH2 and preproGnRH3 were conserved, although there is a change in the amino acid at the position 8 of the $\mathrm{GnRH} 3$ decapeptide of $A$. altiparanae. Furthermore, the induced reproduction by water level drawdown was effective, and in captivity, the $A$. altiparanae has an asynchronous development with splitted spawning during the breeding season. The analysis of the animals submitted to the reproductive stimulus allowed us to suggest that in $A$. altiparanae, the $\mathrm{GnRH} 2$ probably has a role in sexual behavior and the $\mathrm{GnRH} 3$ possibly is the hypophysiotropic form. Finally, analyzing the $\mathrm{GnRH}$ effects, we observed that only the $\mathrm{GnRH} 2$ was able to start the entire reproductive hormonal cascade, leading the animal to spawning.

Keywords: Lambari. GnRHs. Steroids. Gonadotropins. Reproduction. Induction of reproduction. 


\section{LISTA DE ILUSTRAÇÕES}

FIGURA 1. Astyanax altiparanae (LAMBARIS DO RABO AMARELO) EM (A) UM EXEMPLAR REPRESENTATIVO DE FÊMEAS E EM (B) UM EXEMPLAR REPRESENTATIVO DE MACHOS. 57

FIGURA 2. ESQUEMA DEMONSTRANDO O DESENHO EXPERIMENTAL PARA A INDUÇÃO A REPRODUÇÃO PELA REDUÇÃO DO NÍVEL DA ÁGUA. 59

FIGURA 3. MAPA DO VETOR PGEM-T EASY MOSTRANDO O SÍTIO DE INSERÇÃO DO FRAGMENTO, COM OS DIVERSOS POSICIONAMENTOS DOS SÍTIOS DE RESTRIÇÃO PARA VÁRIAS ENZIMAS E A LOCALIZAÇÃO DOS DOIS PROMOTORES PARA INÍCIO DA TRANSCRIÇÃO. 64

FIGURA 4. MAPA DO VETOR ZERO BLUNT® MOSTRANDO O SÍTIO DE INSERÇÃO DO FRAGMENTO, COM OS DIVERSOS POSICIONAMENTOS DOS SÍTIOS DE RESTRIÇÃO PARA VÁRIAS ENZIMAS. 68

FIGURA 5. A SEQUÊNCIA COMPLETA DO cDNA E DA PREDITA SEQUÊNCIA DE AMINOÁCIDOS DO PREPROGnRH2 DE Astyanax altiparanae. A SEQUÊNCIA TOTAL DE NUCLEOTÍDEOS APRESENTA 612 PB, SENDO 158 PB DA REGIÃO NÃO CODIFICANTE 5’UTR, 258 PB DA PREDITA FASE DE LEITURA ABERTA (ORF) QUE CODIFICA UMA PROTEÍNA DE 86 AMINOÁCIDOS E 196 PB DA REGIÃO NÃO CODIFICANTE 3’UTR. 75

FIGURA 6. ALINHAMENTO DAS PREDITAS SEQUÊNCIAS DE AMINOÁCIDOS A PARTIR DO cDNA DO PREPROGnRH2 DE Astyanax altiparanae E OUTRAS ESPÉCIES DE TELEÓSTEOS. AS SEQUÊNCIAS FORAM OBTIDAS NO BANCO DE DADOS DO GENBANK. OS RESÍDUOS DE AMINOÁCIDOS DIFERENTES ESTÃO ENVOLTOS POR UMA CAIXA DA COR PRETA. 76 
FIGURA 7. A SEQUÊNCIA COMPLETA DO cDNA E DA PREDITA SEQUÊNCIA DE AMINOÁCIDOS DO PREPROGnRH3 DE Astyanax altiparanae. A SEQUÊNCIA TOTAL DE NUCLEOTÍDEOS APRESENTA 407 PB, SENDO 13 PB DA REGIÃO NÃO CODIFICANTE 5’UTR, 294 PB DA PREDITA FASE DE LEITURA ABERTA (ORF) QUE CODIFICA UMA PROTEÍNA DE 98 AMINOÁCIDOS E 99 PB DA REGIÃO NÃO CODIFICANTE 3’UTR. 77

FIGURA 8. ALINHAMENTO DAS PREDITAS SEQUÊNCIAS DE AMINOÁCIDOS A PARTIR DO cDNA DO PREPROGnRH3 DE Astyanax altiparanae E OUTRAS ESPÉCIES DE TELEÓSTEOS. AS SEQUÊNCIAS FORAM OBTIDAS NO BANCO DE DADOS DO GENBANK. OS RESÍDUOS DE AMINOÁCIDOS DIFERENTES ESTÃO ENVOLTOS POR UMA CAIXA DA COR PRETA. 78

Figura 9. ÁRVORE FILOGENÉTICA BASEADA NO ALINHAMENTO DE AMINOÁCIDOS DOS PREPRO GnRH2 DE VERTEBRADOS. OS VALORES DE BOOTSTRAP (\%) PRESENTE EM CADA NÓ SÃO REPRESENTADOS POR 1000 REPLICATAS. 80

FIGURA 10. ÁRVORE FILOGENÉTICA BASEADA NO ALINHAMENTO DE AMINOÁCIDOS DOS PREPROGnRH3 DE TELEÓSTEOS. OS VALORES DE BOOTSTRAP (\%) PRESENTE EM CADA NÓ SÃO REPRESENTADOS POR 1000 REPLICATAS.

FIGURA 11. GRÁFICOS DEMONSTRANDO A VARIAÇÃO NA RAZÃO GONADOSSOMÁTICA (RGS) DE FÊMEAS (H=16,388; $\mathrm{P}=0,037$ - KRUSCAL WALLIS) EM (A) E DE MACHOS ( $F=1,806 ; P=0,120$ - ONE WAY ANOVA) EM (B). 82

FIGURA 12. FOTOMICROGRAFIAS DE GÔNADAS DE Astyanax altiparanae, SUBMETIDOS A INDUÇÃO A REPRODUÇÃO POR REDUÇÃO DO NÍVEL DA 
ÁGUA, DEMOSTRANDO DIFERENTES TEMPOS AMOSTRAIS (CORADO COM HEMATOXILINA-EOSINA). (A) OVÁRIO NA FASE APTO A REPRODUÇÃO DO PERÍODO DE -4H A 4H; (B) OVÁRIO NA MESMA FASE APTO A REPRODUÇÃO, MAS COM COMPLEXOS PÓS-OVULATÓRIOS, PERÍODO DE $8 \mathrm{H}$ E 12H; (C) OVÁRIO NA SUBFASE REPRODUTIVA ÀS 16H PÓS-ESTÍMULO (D) OVÁRIO DURANTE A FASE DE REGRESSÃO NO PERÍODO DE 20H A 28H PÓS-ESTÍMULO; (E) TESTÍCULOS NA FASE APTOS `À REPRODUÇÃO DO PERÍODO DE 4 HORAS ANTES DO ESTÍMULO À 8 HORAS APÓS O ESTÍMULO; (F) TESTÍCULOS NA SUBFASE REPRODUTIVA NO PERÍODO DE 12H; (G) TESTÍCULOS RETORNANDO A FASE APTO A REPRODUÇÃO NO PERÍODO DE 16H A 28H. ABREVIAÇÕES: In - OÓCITO INICIAL; Pvt OÓCITOS PRÉ-VITELOGÊNICO; Vt - OÓCITO VITELOGÊNICO; POC COMPLEXO PÓS OVULATÓRIO; GVBD - OÓCITOS MADUROS (OÓCITOS COM A QUEBRA DA VESÍCULA GERMINATIVA); Atr - ATRESIA; Sc1 ESPERMATÓCITO PRIMÁRIO; Sc2 - ESPERMATÓCITO SECUNDÁRIO; St ESPERMATÍDES; Sz - ESPERMATOZOIDES. 84

FIGURA 13. GRÁFICO DEMONSTRANDO A ANÁLISE QUANTITATIVA DAS PROPORÇÕES DE CLASSE CELULARES GONADAIS DE FÊMEAS. 85

FIGURA 14. GRÁFICO DEMONSTRANDO A ANÁLISE QUANTITATIVA DAS PROPORÇÕES DE CLASSE CELULARES GONADAIS DE MACHOS. 86

FIGURA 15. NÍVEIS DE EXPRESSÃO DE mRNA GnRH2 NO ENCÉFALO DE Astyanax altiparanae DURANTE O ESTÍMULO REPRODUTIVO POR REDUÇÃO DO NÍVEL DA ÁGUA (A- FÊMEAS; B- MACHOS). OS NÍVEIS DE mRNA GnRH2 NORMALIZADOS COM OS NÍVEIS DE mRNA EF-1a (ELONGATION FACTOR 1ALPHA) NO ENCÉFALO DE Astyanax altiparanae DURANTE O ESTÍMULO REPRODUTIVO FORAM ANALISADOS POR qRT-PCR. VALORES COM ASTERISCO SÃO SIGNIFICATIVAMENTE DIFERENTES $(p<0,05)$. OS VALORES 
SÃO EXPRESSOS PELA MÉdIA \pm EP $(\mathrm{N}=4)$ (TESTE ONE WAY ANOVA SEGUIDO DO PÓS TESTE DE TUKEY).

FIGURA 16. NÍVEIS DE EXPRESSÃO DE mRNA GnRH3 NO ENCÉFALO DE Astyanax altiparanae DURANTE O ESTÍMULO REPRODUTIVO POR REDUÇÃO DO NÍVEL DA ÁGUA (A- FÊMEAS; B- MACHOS). OS NÍVEIS DE mRNA GnRH 3 NORMALIZADOS COM OS NÍVEIS DE mRNA EF-1a (ELONGATION FACTOR 1ALPHA) NO ENCÉFALO DE Astyanax altiparanae DURANTE O ESTÍMULO REPRODUTIVO FORAM ANALISADOS POR qRT-PCR. VALORES COM ASTERISCO SÃO SIGNIFICATIVAMENTE DIFERENTES $(p<0,05)$. OS VALORES SÃO EXPRESSOS PELA MÉDIA \pm EP $(\mathrm{N}=4)$ (TESTE ONE WAY ANOVA SEGUIDO DO PÓS TESTE DE TUKEY). 88

FIGURA 17. GRÁFICOS DEMONSTRANDO A VARIAÇÃO DA RELAÇÃO GONADOSSOMÁTICA (RGS) DE FÊMEAS EM (A) INJETADAS COM O GnRH1 E DO CONTROLE ( $F=1,59 \mathrm{E} p=0,19)$ EM (B) INJETADAS COM O GnRH2 E DO CONTROLE $(F=0,28 \mathrm{E} p=0,88)$ E EM (C) DE FÊMEAS INJETADAS COm GnRH3 E DO CONTROLE ( $F=0,60 \mathrm{E} p=0,66)$ (TWO-WAY ANOVA). 89

FIGURA 18. FOTOMICROGRAFIAS DE CORTES DE OVÁRIOS, CORADOS COM H\&E, DE Astyanax altiparanae, 4 HORAS ANTES DO TRATAMENTO, ASSIM COMO DOS ANIMAIS QUE FORAM SUBMETIDOS A INJEÇÕES DOS GnRHs 1,2 E $3(0,5 \mu \mathrm{g} / \mathrm{g}$ DA MASSA CORPÓREA) E SALINA NO CASO DO GRUPO CONTROLE. (A-E) OVÁRIOS DO GRUPO CONTROLE DE ANIMAIS INJETADOS COM SALINA. (F-J) OVÁRIOS DO GRUPO DOS ANIMAIS INJETADOS COM GnRH1. (K-O) OVÁRIOS DO GRUPO INJETADO COM GnRH2. (P-T) OVÁRIOS DO GRUPO INJETADO COM GnRH3. ABREVIAÇÕES: OÓCITOS INICIAIS (In), PRÉ-VITELOGÊNICOS (pvt), VITELOGÊNICOS (Vt), OÓCITOS ATRÉSICOS (A) E COMPLEXO PÓS-OVULATÓRIO (POC) 
FIGURA 19. GRÁFICOS DEMONSTRANDO A ANÁLISE QUANTITATIVA DAS PROPORÇÕES DE CLASSE CELULARES GONADAIS DE FÊMEAS DOS GRUPOS TRATADOS COM GRRHS, DO GRUPO CONTROLE E BASAL EM (A) ÀS 2 HORAS PÓS-INJEÇÃO, EM (B) ÀS 4 HORAS PÓS-INJEÇÃO, EM (C) ÀS 10 HORAS PÓS-INJEÇÃO, EM (D) ÀS 16 HORAS PÓS-INJEÇÃO E EM (E) ÀS 24 HORAS PÓS-INJEÇÃO. 93

FIGURA 20. NÍVEIS DE EXPRESSÃO DE mRNA ßLH NA HIPÓFISE DE FÊMEAS DE Astyanax altiparanae SUBMETIDAS A INJEÇÃO COM GnRH1 EM (A), A INJEÇÃO DE GnRH2 EM (B) E A INJEÇÃO DE GnRH3 EM (C) COMPARADO AO GRUPO CONTROLE E BASAL. OS NÍVEIS DE MRNA $\beta L H$ NORMALIZADOS COM OS NÍVEIS DE mRNA EF-1a (ELONGATION FACTOR 1ALPHA) NA HIPÓFISE DE Astyanax altiparanae FORAM ANALISADOS POR qRT-PCR. VALORES COM ASTERISCO SÃO SIGNIFICATIVAMENTE DIFERENTES $(p<0,05)$. A SETA É REPRESENTATIVA DO MOMENTO EM QUE HOUVE A INJEÇÃO. OS VALORES SÃO EXPRESSOS PELA MÉDIA \pm EP $(\mathrm{N}=5)$ (TESTE TWO-WAY ANOVA SEGUIDO DO PÓS TESTE DE BONFERRONI).....99

FIGURA 21. NÍVEIS DE EXPRESSÃO DE mRNA $\beta F S H$ NA HIPÓFISE DE FÊMEAS DE Astyanax altiparanae SUBMETIDAS A INJEÇÃO COM GnRH1 EM (A), A INJEÇÃO DE GnRH2 EM (B) E A INJEÇÃO DE GnRH3 EM (C) COMPARADO AO GRUPO CONTROLE E BASAL. OS NÍVEIS DE mRNA $\beta F S H$ NORMALIZADOS COM OS NÍVEIS DE mRNA EF-1 $\alpha$ (ELONGATION FACTOR 1ALPHA) NA HIPÓFISE DE Astyanax altiparanae FORAM ANALISADOS POR qRT-PCR. VALORES COM ASTERISCO SÃO SIGNIFICATIVAMENTE DIFERENTES $(p<0,05)$. A SETA É REPRESENTATIVA DO MOMENTO EM QUE HOUVE A INJEÇÃO. OS VALORES SÃO EXPRESSOS PELA MÉDIA \pm EP (N=5) (TESTE TWO-WAY ANOVA SEGUIDO DO PÓS TESTE DE BONFERRONI)..... 95 
FIGURA 22. CONCENTRAÇÃO PLASMÁTICA TEMPORAL DE 17 $\alpha 20 \beta$ DIHIDROXI-4PREGNEN-3-ONE (17,20 DHP) EM FÊMEAS DE Astyanax altiparanae SUBMETIDAS A INJEÇÃO COM GnRH1 EM (A), A INJEÇÃO DE GnRH2 EM (B) E A INJEÇÃO DE GnRH3 EM (C) COMPARADO AO GRUPO CONTROLE E BASAL. VALORES COM ASTERISCO SÃO SIGNIFICATIVAMENTE DIFERENTES $(p<0,05)$. A SETA É REPRESENTATIVA DO MOMENTO EM QUE HOUVE A INJEÇÃO. OS VALORES SÃO EXPRESSOS PELA MÉDIA \pm EP $(\mathrm{N}=5)$ (TESTE TWO-WAY ANOVA SEGUIDO DO PÓS TESTE DE BONFERRONI). 


\section{LISTA DE TABELAS}

TABELA 1. SEQUÊNCIA DOS PRIMERS E A FINALIDADE DE CADA TÉCNICA

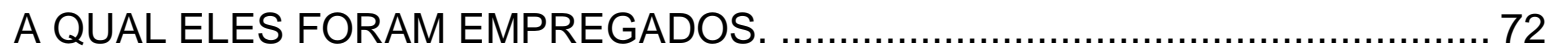

TABELA 2. AMPLITUDE DO COEFICIENTE DE VARIAÇÃO INTRAENSAIO E INTERENSAIO, E NÚMERO AMOSTRAL UTILIZADO PARA A VALIDAÇÃO DO ENSAIO DE 17 $\alpha 20 \beta$ DIHIDROXI-4PREGNEN-3-ONE (17,20 DHP) EM PLASMA

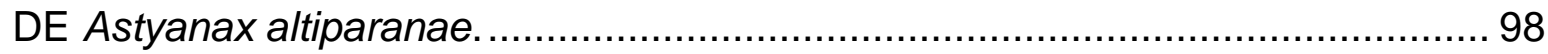




\section{LISTA DE ABREVIATURA}

Aa - Aminoácido.

AR - Receptor de andrógeno.

Atr - Atresia.

BLAST - Basic Local Alignment Search Tool

CA - Oócito alvéolo cortical.

CaM - Calmodulina

cAMP - Adenosina 3',5'-monofosfato cíclico.

Cdc25 - ciclina dependente de cinase.

cDNA - DNA complementar.

CESP - Companhia energetica do estado de São Paulo.

CIP - Fosfatase alcalina.

CYP - Enzima do citocromo P450.

CYP11a - Enzima de clivagem da cadeia lateral do colesterol.

CYP19 - Aromatase.

DAG - Diacylglicerol.

DEPC - Dietilpirocarbonato.

DIG- Digoxigenina.

DNA - Ácido desoxirribonucleico.

$E_{2}-17 \beta$ estradiol.

EF-1 $\alpha$ - Elongation fator $1 \alpha$.

EHC - Extrato hipofisário de Carpa.

ELISA - Enzyme-Linked Immunosorbent Assay.

EP - Erro padrão.

ER - Receptor de estrógeno.

ERK - Cinase regulatória de sinais extracelulares.

FSH - Hormônio folículo estimulante.

FSHR - Receptor de FSH.

GAP - Proteína acoplada ao GnRH.

$\mathrm{GH}$ - Hormônio do crescimento.

GnRHa - Análogo de GnRH. 
GnRH - Hormônio liberador de gonadotropinas.

GnRHR - Receptor de GnRH.

GPCR - Receptor acoplado a proteína G.

GtH - Gonadotropina.

GVBD - Oócitos maduros (oócitos com a quebra da vesícula germinativa).

hCG - Gonadotropina coriônica humana.

HMGR - 3-hydroxy-3-methylglutaryl-coenzima A reductase.

In - Oócito inicial.

IP3 - Inositol trifosfatado.

IPTG - Isopropil-B-D-tiogalactosídeo.

Kiss - Kisspeptina.

LH - Hormônio luteinizante.

LHR - Receptor de LH.

LHRH - Hormônio liberador de hormônio luteinizante.

mRNA - RNA mensageiro.

MAPK - Proteína-cinases ativadas por mitógenos.

MIS - Esteróide indutor da maturação.

MPF - Fator promotor da maturação.

ORF - Open reading frame.

$\mathrm{pb}$ - Pares de bases.

PCR - Reação em cadeia da polimerase.

P450scc - Enzima de clivagem da cadeia lateral do colesterol.

$\mathrm{Pg}$ - Peso das gonadas.

PhyML - Máximo verossimilhança.

PLC - Fosfolipase C.

PKA - proteína cinase $A$.

PKC - proteína cinase $C$.

POC - Complexo pós-ovulatório.

$P R L$ - Prolactina.

Pt - Peso total.

Pvt - Oócitos pré-vitelogênico.

RACE - Rapid amplification of $c D N A$ ends.

RGS - Relação gonadossomática. 
RNA- Ácido ribonucleico.

Sc1 - Espermatócito primário.

Sc2 - Espermatócito secundário.

SL - Somatolactina.

St - Espermátides.

StAR - Proteína reguladora aguda esteroidogênica.

Sz - Espermatozoides.

TAP - Pirofosfatase ácida.

UTR - Untranslated region.

Vt - Oócito vitelogênico.

Vtg - Oócito vitelogênico.

VTG - Vitelogenina.

X-gal - 5-bromo-4-cloro-3-indoil-B-D-galactosídeo.

$3 \beta H S D$ - $3 \beta$-hidroxiesteróide desidrogenase.

11-KT - 11-cetotestosterona.

$11 \beta-\mathrm{H}$ - 11ß-hydroxilase.

$11 \beta$-HSD - 11ß-hidroxiesteróide desidrogenase.

17,20 DHP - 17 $\alpha 20 \beta$ dihidroxi-4pregnen-3-one.

20ßHSD - 20ß-hidroxiesteróide desidrogenase.

$20 \beta-S$ - 17a20ß, 21 -trihydroxy-4-pregnane-3-one.

\section{Aminoácidos}

G - Licina.

A - Alanina.

L - Leucina.

V - Valina.

I - Isoleucina.

P - Prolina.

F - Fenilalanina.

$S$ - Serina.

$T$ - Treonina.

C - Cisteina.

$\mathrm{Y}$ - Tirosina. 
$\mathrm{N}$ - Asparagina.

Q - Glutamina.

D - Ácido aspártico.

E - Ácido glutâmico.

$R$ - Arginina.

$\mathrm{K}$ - Lisina.

$\mathrm{H}$ - Histidina.

W - Triptofano.

$M$ - Metionina.

\section{Bases nitrogenadas dos nucleotídeos}

A - Adenina.

$T$ - Timina.

C - Citosina.

G - Guanina. 


\section{SUMÁRIO}

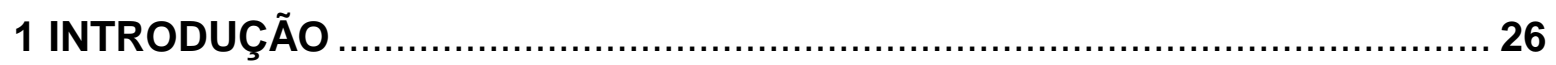

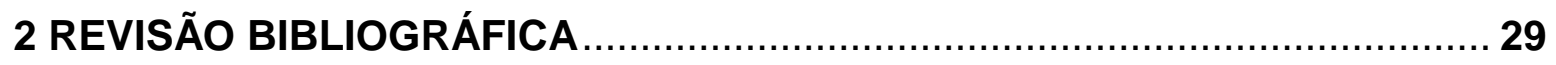

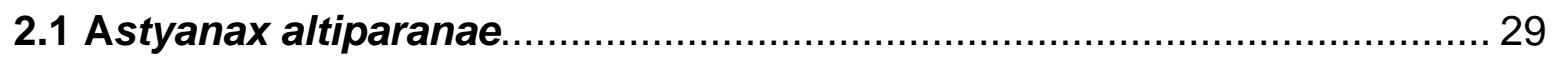

2.2 Hôrmonio liberador de gonadotropinas (GnRH) ................................... 30

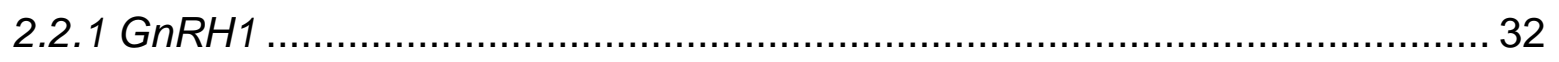

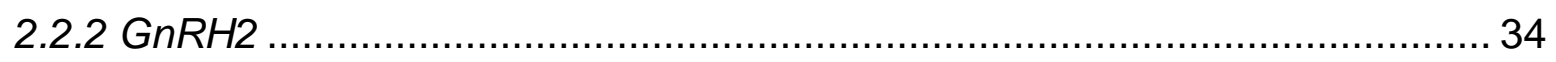

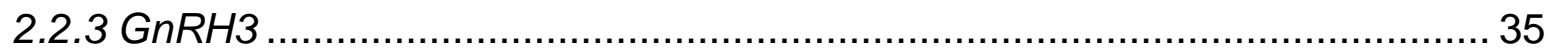

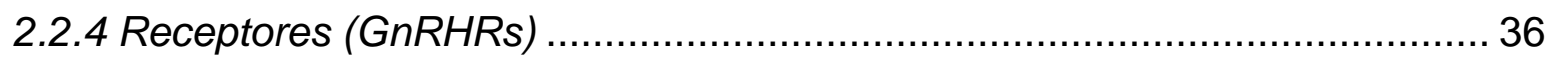

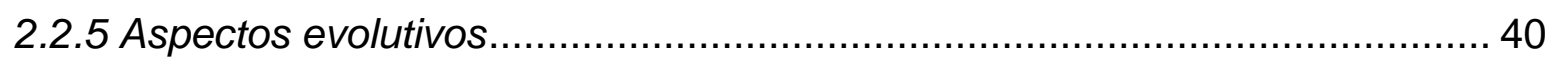

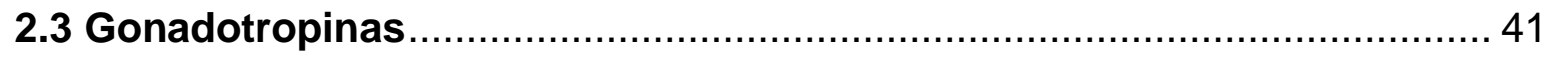

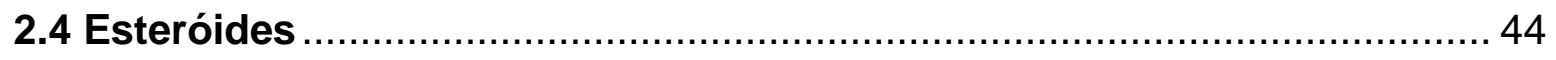

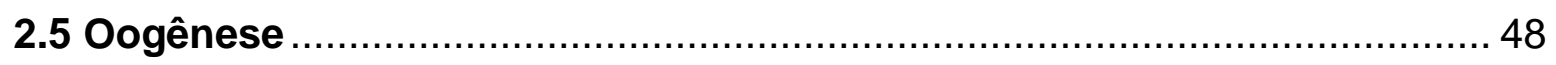

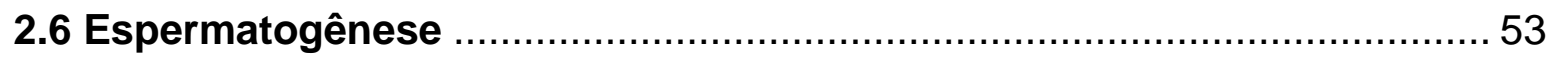

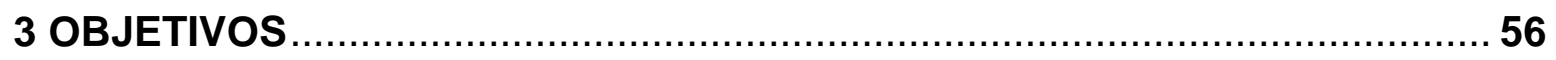

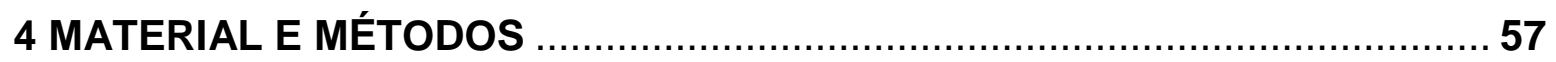

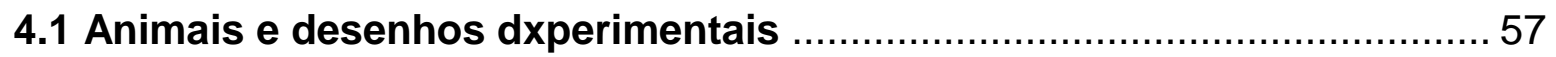

4.1.1 Indução à reprodução por redução do nível da água ....................................5 58

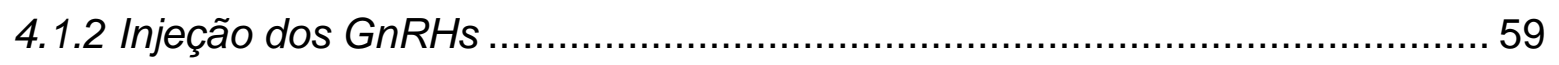

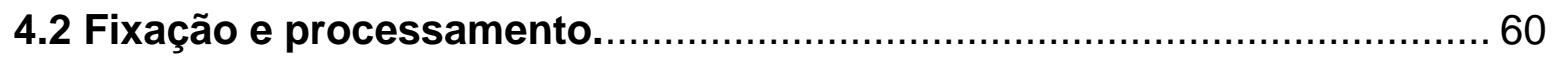

4.3 Análise quantitativa dos tipos celulares gonadais.................................6 60

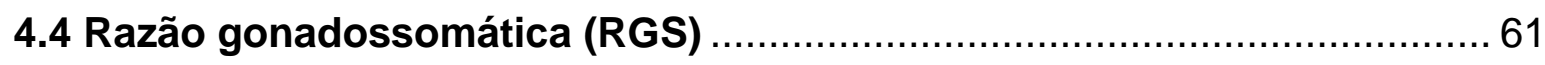

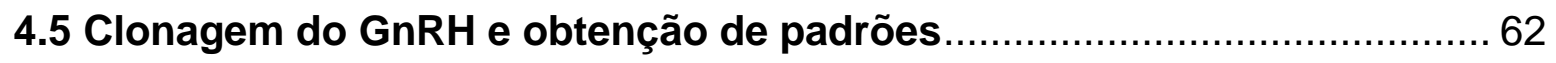

4.5.1 Extração de RNA total e tratamento com DNAse ........................................ 62

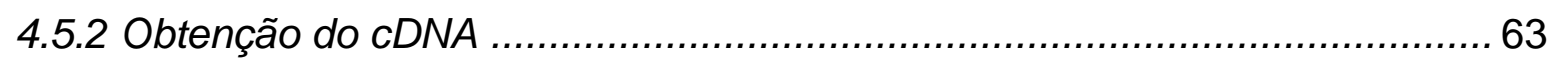

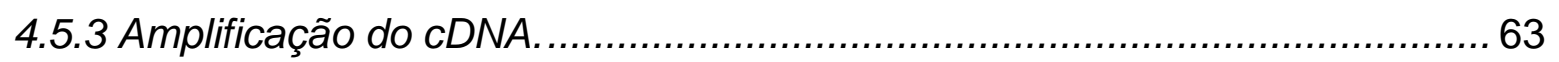

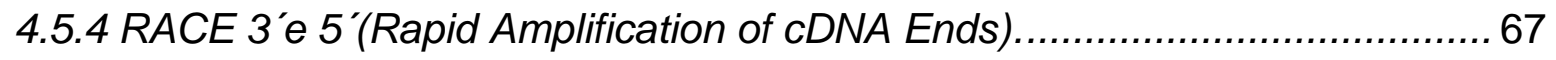

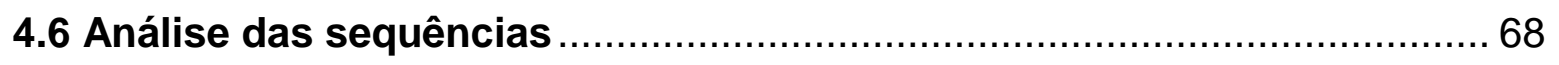

4.7 Análise quantitativa da expressão gênica por reação em cadeia da

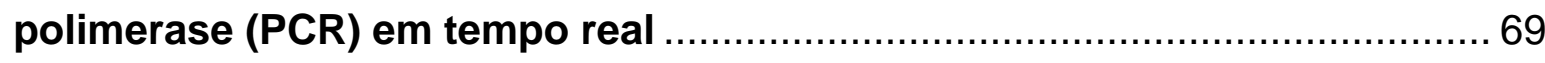


4.8 Determinação do $17 \alpha 20 \beta$ dihidroxi-4pregnen-3-one................................ 72

4.8.1 Validação dos ensaios de ELISA .......................................................... 73

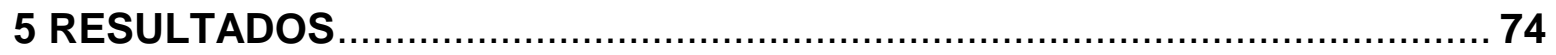

5.1 Caracterização molecular do preproGnRH2 …....................................... 74

5.2 Caracterização molecular do preproGnRH3 ……................................ 76

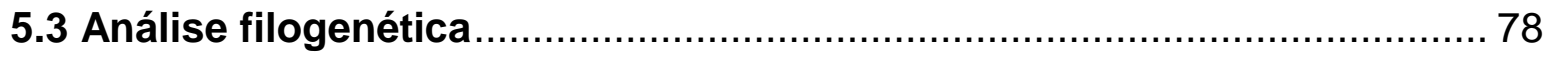

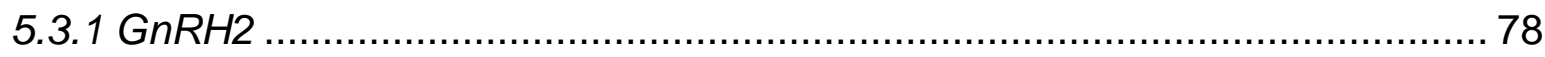

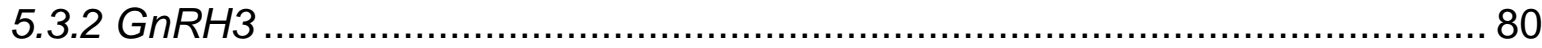

5.4 Indução a reprodução por redução do nível da água ............................. 81

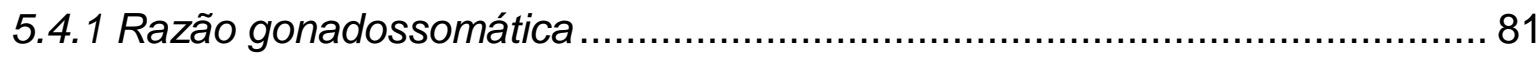

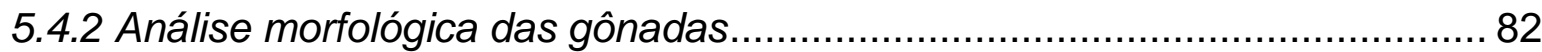

5.4.3 Análise quantitativa das classes celulares gonadais ................................. 85

5.4.4 Expressão gênica temporal do GnRH2 e GnRH3 em Astyanax altiparanae

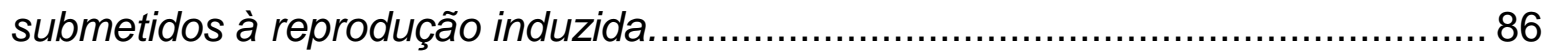

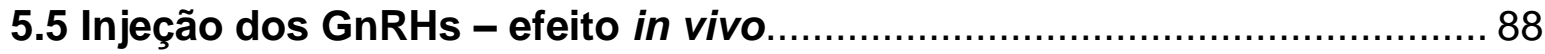

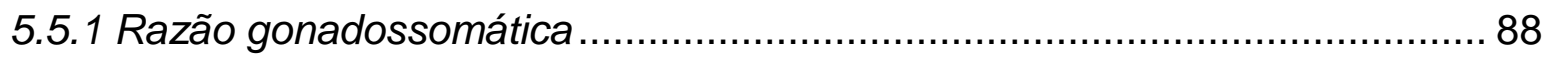

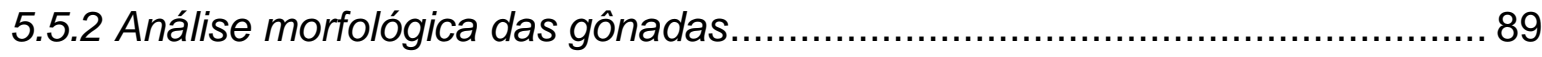

5.5.3 Análise quantitativa das classes celulares gonadais ................................. 92

5.5.4 Expressão gênica temporal do $\beta F S H$ e $\beta L H$ em Astyanax altiparanae

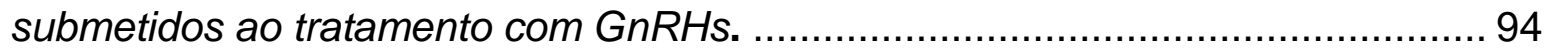

5.5.5 Perfil plasmático de 17 $\alpha 20 \beta$ dihidroxi-4pregnen-3-one (17,20 DHP) em Astyanax altiparanae submetidos ao tratamento com GnRHs ............................ 96

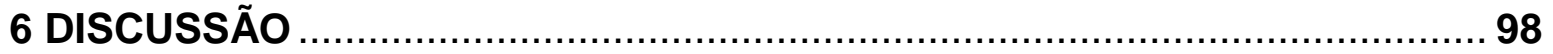

6.1 Sequências dos cDNAs dos preproGnRH2 e preproGnRH3 de Astyanax

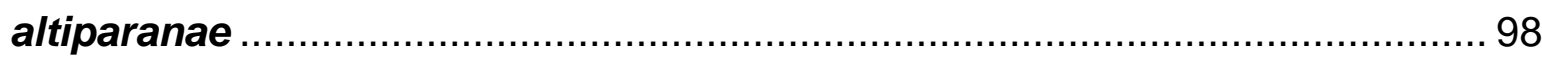

6.2 Indução a reprodução por redução do nível da água ............................ 101

6.3 Injeção dos GnRHs - efeito in vivo .................................................. 106

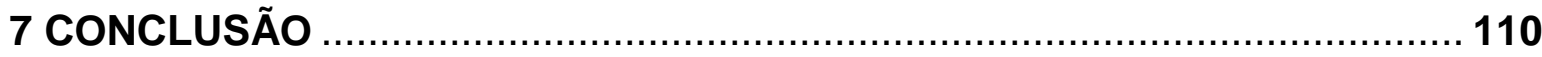

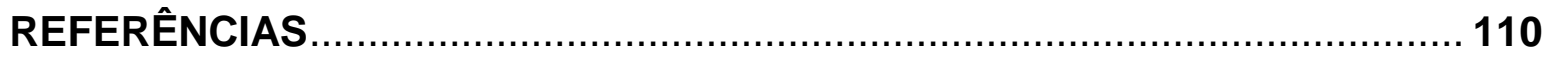

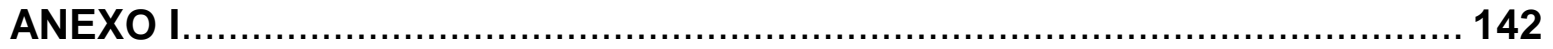




\section{INTRODUÇÃO}

O eixo hipotálamo-hipófise-gônadas desempenha um importante papel na gametogênese em teleósteos, assim como nos demais vertebrados. Por sua vez, o estudo do controle endócrino da reprodução em peixes vem adquirindo importância especial nos últimos anos por representar uma possibilidade de intervenção específica em prol de espécies ameaçadas de extinção. A falta de informações sobre o ciclo reprodutivo de espécies principalmente sul americanas acarreta em dificuldades para a compreensão do processo como um todo, e das consequentes intervenções que levariam em maior eficácia na reprodução em cativeiro destes animais.

Em geral, o processo reprodutivo ocorre da seguinte forma: fatores ambientais como fotoperíodo, temperatura, elevação do nível da água e disponibilidade de alimento associados às condições fisiológicas do indivíduo sinalizam para o hipotálamo uma estação reprodutiva, assim o hipotálamo passa a sintetizar e liberar o hormônio liberador de gonadotropinas $(\mathrm{GnRH})$ que, regulado pela Kisspeptina (Kiss), estimula as células gonadotrópicas da adeno-hipófise a liberar o hormônio folículo-estimulante (FSH) e o hormônio luteinizante (LH). Em fêmeas adultas, o FSH é transportado até os ovários, atuando na teca folicular dos oócitos em desenvolvimento, onde converte o colesterol em testosterona, a qual é transportada à camada folicular, e aromatizada a $17 \beta$-estradiol $\left(E_{2}\right)$ pela enzima aromatase (NAGAHAMA, 1994). O $\mathrm{E}_{2}$ é, por sua vez, transportado até o fígado, onde estimula a síntese de glicolipofosfoproteína vitelogenina (VTG), a qual é incorporada pelos oócitos por micropinocitose. Com a elevação plasmática do $\mathrm{E}_{2}$, a hipófise, estimulada pelo $\mathrm{GnRH}$, passa a secretar $\mathrm{LH}$, que atua sobre as camadas foliculares oocitárias, estimulando a síntese do $17 \alpha 20 \beta$ dihidroxi4pregnen-3-one (17,20 DHP), o hormônio da maturação final e ovulação para a maioria dos teleósteos (NAGAHAMA, 1994). Já em machos, o controle endócrino reprodutivo ocorre de maneira semelhante ao das fêmeas, sendo um processo complexo onde são envolvidas as gonadotropinas, $\mathrm{FSH}$ e $\mathrm{LH}$, e os hormônios esteróides sexuais como estrógenos, andrógenos e progestágenos; no entanto, 
em machos, o esteróide sexual responsável pelas fases iniciais de proliferação é a 11-cetotestoterona (MIURA; MIURA, 2003).

A reprodução em peixes migradores, os quais representam grande proporção das espécies nativas de água doce, não ocorre quando os mesmos estão confinados, apesar das fêmeas normalmente apresentarem 0 desenvolvimento oocitário normal; porém, não conseguem eliminá-los ao meio externo ao final do período reprodutivo sem que haja indução hormonal adequada (MYLONAS; ZOHAR, 2007), e o motivo pelo qual ocorre este fenômeno ainda não é conhecido.

Diante disso, vem sendo testado inúmeras técnicas de indução a reprodução, dentre elas a mais utilizada no Brasil é o extrato hipofisário de carpa (EHC) (BOCK; PADOVANI, 2000; ZANIBONI-FILHO; WEINGARTNER, 2007), a qual, normalmente as fêmeas recebem duas doses do $\mathrm{EHC}(0,5$ e $5 \mathrm{mg} / \mathrm{Kg}) \mathrm{com}$ intervalo de 10 a 12 horas (WOYNAROVICH; HORVÁTH, 1983), assim ocorre a retomada da meiose e a maturação final do oócitos (MYLONAS; FOSTIER; ZANUY, 2010; NAGAHAMA; YAMASHITA, 2008). Em alguns casos os machos recebem também o extrato hipofisário, mas os efeitos causados pelo conteúdo hormonal são principalmente o aumento do volume de ejaculado e a indução a espermiação (MYLONAS; ZOHAR, 2001; MYLONAS; FOSTIER; ZANUY, 2010; ZANIBONI-FILHO; WEINGARTNER, 2007). Outras técnicas como o uso de hCG (gonadotropina coriônica humana) (ROMAGOSA; PAIVA; GODINHO, 1990), GnRHa (CAROLSFELD et al., 1988) ou então de manipulações de parâmetros ambientais como fotoperíodo, temperatura da água, profundidade e/ou volume de água (MYLONAS; ZOHAR, 2007) também são empregadas na piscicultura a fim de obter um sucesso reprodutivo em cativeiro. No entanto, até mesmo os processos de indução a reprodução apresentam falhas, onde principalmente as fêmeas não respondem ao tratamento hormonal. Este fato se deve provavelmente a diversos fatores, entre eles encontra se a falta de informação cientifica sobre a biologia da espécie em questão (BOBE; LABBÉ, 2010; MYLONAS; FOSTIER; ZANUY, 2010). 
Com isso, investigações no eixo reprodutivo em espécies sul americanas, que apresentam pouca informação na literatura a respeito da biologia reprodutiva, devem ser realizadas a fim de se compreender melhor o mecanismo reprodutivo para que se entenda o porque dessas espécies não conseguirem reproduzir naturalmente em cativeiro, como também realizar mais estudos de indução a reprodução para que se possa aumentar a produtividade, atendendo a demanda alimentar.

Dessa forma, decidimos estudar alguns aspectos do eixo reprodutivo de um teleósteo sul americano Astyanax altiparanae (lambari), pertencente à classe Actinopterygii, ordem Characiformes, e família Characidae (GARUTTI; BRITSKI, 2000), os quais foram submetidos à indução à reprodução pela redução do nível da água. Além disso, foram estudados também os efeitos de diferentes GnRHs nessa espécie e a caracterização molecular do mRNA do preproGnRH2 e do preproGnRH3.

Tal estudo vem agregar informações sobre as alterações morfológicas das gônadas e expressão do mRNA de GnRH2 e do mRNA de GnRH3 durante o estímulo reprodutivo, acrescentando informações a respeito da biologia reprodutiva de Astyanax altiparanae, principalmente em relação às fêmeas, uma vez que, para nosso conhecimento, os trabalhos na literatura a este respeito são escassos. Em relação às sequências gênicas do preproGnRH2 e preproGnRH3 de Astyanax altiparanae, trabalhos futuros poderão ser desenvolvidos envolvendo o $\mathrm{GnRH} 2$ e GnRH3 de espécies de peixes da ordem Characiformes como um todo, uma vez que estes dados não existiam na literatura até o momento. Além disso, o presente trabalho traz informações a respeito dos efeitos dos GnRHs em Astyanax altiparanae, que posteriormente poderão ser usadas em pisciculturas, para a indução hormonal da reprodução, já que do ponto de vista ecológico e econômico, a utilização de $\mathrm{GnRH}$ para a indução da reprodução oferece grandes vantagens uma vez que atua no inicio da cascata hormonal fazendo com que o animal produza suas próprias gonadotropinas, eliminando assim os problemas relacionados à utilização de gonadotropinas de outras espécies, como ocorre no processo de hipofisação, além de preservar um grande número de animais que 
seriam sacrificados para a obtenção de hipófises para produção da dose necessária à indução.

\section{REVISÃO BIBLIOGRÁFICA}

\subsection{Astyanax altiparanae}

A espécie Astyanax altiparanae, conhecida popularmente por lambari do rabo amarelo, é um teleósteo sul americano, pertencente à classe Actinopterygii, ordem Characiformes, família Characidae e subfamília Tetragonopterinae (GARUTTI; BRITSKI, 2000).

A ordem Characiformes consiste em aproximadamente 18 famílias, 270 gêneros e mais de 1700 espécies. Apresenta grande importância comercial, relacionada com alimentação, a exemplo do pacu, curimbatá, dourado e lambari, além de ter importância ecológica e acadêmica. A maior parte dos representantes dessa ordem são espécies de piracema, ou seja, que necessitam migrar para reproduzir, e apresentam dificuldade em desovar quando mantidos em cativeiro.

O gênero Astyanax (BAIRD; GIRARD, 1954) apresenta um grande número de espécies e subespécies; devido a esta diversidade do gênero, muitos aspectos da taxonomia se mantem obscuros fazendo com que identificações na literatura apareçam de forma incorreta, como foi caso do Astyanax altiparanae que por muitos anos foi identificado como Astyanax bimaculatus, até que GARUTTI e BRITSKI, no ano de 2000, fizeram toda a descrição morfológica e taxonômica do lambari do rabo amarelo, diferenciando-o do $A$. bimaculatus, e uma das diferenças

está na localização das duas espécies, sendo $A$. altiparanae encontrado na Bacia do alto do rio Paraná enquanto $A$. bimaculatus está localizado no Suriname e na Bacia Amazônica (GARUTTI; BRITSKI 2000).

O Astyanax altiparanae é uma espécie que apresenta dieta onívora, atividade alimentar no período diurno (CASATTI; LANGEANI; CASTRO, 2001; ESTEVES; GALETTI JÚNIOR, 1995; GOMIERO; BRAGA, 2003) e número diploide de 50 cromossomos tanto para machos como para fêmeas não havendo 
dimorfismo sexual neste aspecto (KAVALCO et al., 2011). Ainda em relação ao dimorfismo sexual é possível observar em machos a nadadeira anal áspera com a presença de espículas, diferentemente de fêmeas, sendo assim fácil a identificação do sexo nesta espécie.

Algumas características do lambari do rabo amarelo conferem a esta espécie uma grande importância acadêmica, apresentando pequeno porte, atingindo de 7 a $15 \mathrm{~cm}$ de comprimento, podendo alcançar 60 gramas de peso, fácil manejo, possuem oócitos pequenos, elevada fecundidade relativa, rápido desenvolvimento, chegando à maturidade sexual com cerca de quatro meses de idade em condições de cultivo, normalmente com 7 a $9 \mathrm{~cm}$ de comprimento para os machos e 12 a $15 \mathrm{~cm}$ de comprimento para as fêmeas (PORTO FORESTI et al., 2001), fertilização externa, ausência de cuidado parental (AGOSTINHO et al., 1999; SUZUKI et al., 2005) e são um ótimo bioindicador de ambientes poluídos, apresentando um grande potencial para ser utilizado como modelo biológico de estudos. Além disso, esta espécie apresenta grande importância ecológica, contribuindo para o equilíbrio dos ecossistemas de água doce brasileiros, já que participa de diferentes níveis tróficos da cadeia alimentar. Estudos com esta espécie estão sendo atualmente desenvolvidos no Laboratório de Endocrinologia de peixes do ICB, USP.

Dados na literatura a respeito da biologia reprodutiva do Astyanax altiparanae são escassos. Com relação às informações sobre o $\mathrm{GnRH}$ nesta espécie até mesmo na ordem Characiformes, são raras, tendo sido encontradas apenas para pacu (POWELL et al., 1997), curimbatá (SOMOZA et al., 1994) e lambari (GOMES; COSTA; BORELLA, 2013). Entretanto, não são conhecidos até hoje trabalhos que descrevam a sequência gênica do $\mathrm{GnRH}$, assim como seus efeitos nestes animais.

\subsection{Hormônio liberador de gonadotropinas (GnRH)}

Uma das moléculas chave que desencadeia toda a cascata hormonal derivada do eixo reprodutivo é o $\mathrm{GnRH}$, um neuropeptídeo com dez aminoácidos, 
que foi isolado primeiramente no encéfalo de porcos (MATSUO et al., 1971) e ovelhas (BURGUS et al., 1972), o qual recebeu o nome de LHRH (hormônio estimulador do hormônio luteinizante) por estimular o LH. Posteriormente, foi visto que esta molécula também atua na síntese e liberação de FSH recebendo então o nome mais genérico de $\mathrm{GnRH}$ (hormônio liberador de gonadotropinas).

A expressão e síntese do GnRH são influenciadas por fatores ambientais e fisiológicos, como: estação e fotoperíodo (HILDAHL et al., 2013), temperatura (DAVID; DEGANI, 2011), stress e nível de cortisol (OAKLEY et al., 2009), resposta imune (KARSCH; BATTLAGLIA 2002), feedback de esteróides gonadais (LEE; LEE; CHOW, 2008) entre outros.

Em geral, a principal função do $\mathrm{GnRH}$ é a reprodutiva, a qual o $\mathrm{GnRH}$ sintetizado no hipotálamo alcança as células gonadotrópicas indiretamente via sistema porta hipofisário (em tetrápodes) ou diretamente via terminal axonal (teleósteos) (DUBOIS et al., 2002). No entanto, é visto que o GnRH apresenta diversas funções como: neuromodulação com implicações na modulação do comportamento sexual (SOGA et al., 2005), controle da secreção de prolactina (PRL), do hormônio do crescimento (GH) (KLAUSEN; CHANG; HABIBI, 2002) e de somatolactina (SL) (ONUMA et al., 2005; CÁNEPA et al., 2008) pela hipófise. Além disso, foi visto que o GnRH pode estar envolvido na modulação da secreção de melatonina (SERVILI et al., 2010) pela pineal.

Em vertebrados, geralmente são encontradas de 2 a 3 formas de $\mathrm{GnRH}$ em um único indivíduo, sendo anteriormente cada uma dessas formas nomeadas de acordo com espécie a qual foi isolada primeiramente, no entanto esta nomenclatura se tornou confusa e obsoleta com o passar dos anos devido ao grande número de formas de GnRHs que foram sendo descobertas. Diante disso, foi proposta uma nova nomenclatura baseada na função, localização e análises filogenéticas, onde a forma encontrada na região hipotalâmica ligada à função reprodutiva recebe o nome de $\mathrm{GnRH1}$. A forma presente na região do tegumento do encéfalo médio, ligada à função de modulação da melatonina, recentemente proposta por SERVILI e colaboradores (2010), é chamada de $\mathrm{GnRH} 2$, e a forma presente no nervo terminal/telencéfalo ventral, e que está relacionada com a 
função de neuromodulação e função reprodutiva dependendo da espécie, recebe o nome de GnRH3 (FERNALD; WHITE, 1999).

Atualmente são encontradas 44 formas de GnRHs entre invertebrados e vertebrados, sendo que treze formas foram isoladas no encéfalo de espécies de peixes, incluindo lampreia (ROCH; BUSBY; SHERWOOD, 2014).

Com isso, serão detalhadas nas próximas seções as três formas parálogas de $\mathrm{GnRH}$ de forma separada, abordando basicamente sua origem, localização e função, além dos receptores de GnRH e aspectos filogenéticos.

\subsubsection{GnRH1}

Os neurônios de GnRH1 tem sua origem no placode olfatório e migram colonizando posteriormente o hipotálamo e área preótica (DUBOIS et al., 2002; MURAKAMI; KIKUYAMA; ARAI, 1992;), onde permanecerão em adultos e desempenharão principalmente a função de estimular a síntese e liberação de LH e FSH na hipófise (KAH et al., 2007).

Foi observado que o período de intensa atividade dos neurônios de $\mathrm{GnRH} 1$, em medaka, é no período da tarde por volta das 16:00 horas, sendo sugerido que este aumento é capaz de em poucos segundos induzir a liberação do LH pelas células gonadotrópicas, o qual será responsável por desencadear a desova durante o período da madrugada e, além disso, o mesmo pico de atividade dos neurônios de $\mathrm{GnRH} 1$ é capaz de induzir de forma mais lenta a transcrição do mRNA de LH que se torna a fonte para o pico de LH no próximo ciclo ovulatório (KARIGO et al., 2012).

A atividade dos neurônios de $\mathrm{GnRH} 1$ da área preótica ventral e dorsal foi medida em medaka por meio de precipitados de DIG (digoxigenina) visualizados pela técnica de hibridização in situ, sendo observado que em menos de 10 minutos já havia aumento do mRNA de $\mathrm{GnRH} 1$ na parte ventral, enquanto na parte dorsal a atividade foi mais demorada, levando por volta de 30 minutos para apresentar mRNA de GnRH1 (KARIGO et al., 2012). 
A maioria das espécies de vertebrados que possuem seu genoma sequenciado expressa o GnRH1 exceto poucas exceções como, por exemplo, o zebrafish (KAH et al., 2007; KUO et al., 2005), Anolis carolinensis (LESCHEID et al., 1997) e Petromyzon marinus (SMITH et al., 2013).

A perda do gene codificante do GnRH1 tem ocorrido de forma independente em poucos grupos de vertebrados embora isso não tenha ocorrido em nenhuma classe completa. Juntamente a isso, a maioria das espécies de vertebrados não mamíferos perderam o gene codificador do receptor de $\mathrm{GnRH}$ do tipo I, mesmo que ainda codifiquem seu ligante $\mathrm{GnRH1,0}$ qual tem capacidade de ativar os receptores tipo II (ROCH; BUSBY; SHERWOOD, 2014).

Já foram descritas 12 formas diferentes de $\mathrm{GnRH} 1$, sendo o $\mathrm{GnRH} 1$ do tipo mamíferos ( $m G n R H 1)$ é encontrado em todos os mamíferos, alguns anfíbios, dois teleósteos (Anguilla anguilla e Pantodon buchholzi), e em uma espécie de peixe cartilaginoso Leucoraja erinacea (LESCHEID et al., 1995; O'NEILL et al., 1998; ROCH; BUSBY; SHERWOOD, 2014; SHERWOOD; DOROSHOV; LANCES, 1991). As outras 11 formas de $\mathrm{GnRH} 1$ são encontradas predominantemente em espécies de vertebrados não mamíferos, variando o tipo de acordo com a espécie.

Existem características filogenéticas que unem os preproGnRH1 no mesmo grupo ortólogo, como a falta do triptofano na posição 7 do decapeptídeo maduro, sendo este aminoácido presente na posição 7 dos peptídeos maduros GnRH2 e GnRH3 (GUILGUR et al., 2006; VICKERS et al., 2004; WHITE et al., 1998), além disso, a sintenia entre varias espécies de vertebrados para o $\mathrm{GnRH} 1$ está bem estabelecida (KIM et al., 2011; OKUBO et al., 2003, ROCH; BUSBY; SHERWOOD, 2014).

Estudos relacionados ao GnRH1 são bem explorados na literatura, provavelmente devido a sua função direta com a reprodução, trazendo junto uma importância econômica, quando se trata de espécies de cultivo, com o aumento da produção e uma importância clínica quando se refere a humanos. 


\subsubsection{GnRH2}

Os neurônios de $\mathrm{GnRH} 2$ tem origem na crista neural cranial, posteriormente migram para o tegumento do mesencéfalo, onde são observados em adulto (LETHIMONIER et al., 2004), no entanto alguns autores acreditam que sua origem seja a zona ventricular do mesencéfalo (PARHAR et al., 1998; WHITE; FERNALD, 1998). Sua expressão durante o desenvolvimento se dá às 24 horas pósfertilização aumentando até 56 horas (GOPINATH; ANDREW TSENG; WHITLOCK, 2004).

$\mathrm{O}$ GnRH2 é a forma mais conservada dentre os $\mathrm{GnRH}$ s sendo expresso na região mesencefálica. Em contraste com $\mathrm{GnRH}_{1}$, os decapeptídeos $\mathrm{GnRH2}$, possuem a mesma sequência em todas as espécies estudadas, e estão presentes na maioria dos vertebrados exceto em agnathas (KING; MILLAR, 1992; SHERWOOD; LOVEJOY; COE, 1993) e em algumas espécies de mamíferos mais derivados, nas quais o gene foi perdido ou inativado (MORGAN et al., 2006; PAWSON et al., 2003).

$O$ fato de ser altamente conservado, estar presente na maioria das espécies e ser a forma mais estável e menos susceptível à ação das peptidases que GnRH1, devido à sua pré-conformação em turn ßII (MILLAR, 2003), sugere uma função importante para $\mathrm{GnRH} 2$ durante a evolução, contudo não existem evidencias farmacológicas, morfológicas e funcionais para dar suporte às funções propostas para este $\mathrm{GnRH}$ em nenhum vertebrado.

O mais comumente aceito é que sua função esteja associada à neuromodulação do comportamento sexual (MANEY; RICHARDSON; WINGFIELD, 1997; VOLKOFF; PETER 1999). Existem algumas observações experimentais que evidenciam esta função como em peixes poecilídeos, onde os neurônios da medula espinhal que controlam $o$ ducto espermático e a contratilidade do oviduto recebem impulsos de células do GnRH2 (MILLER; KRIEBEL, 1986), e em musk shrew, regiões homologas àquelas que controlam o comportamento de lordose em ratos são ricamente inervadas pelas fibras imunorreativas do GnRH2 (RISSMAN et al., 1995). Outra função atribuída ao $\mathrm{GnRH} 2$ é de atuar no sistema imune, onde em pombos foi encontrado 
imunorreatividade ao $\mathrm{GnRH} 2$ em mastócitos na região da habênula após comportamento de corte (SILVER; RAMOS; SILVERMAN, 1992). Imunomarcação ao GnRH2 também foi visto em mastócitos de filhotes de musk shrew (RISSMAN et al., 1995). Acredita-se também que o $\mathrm{GnRH} 2$ pode estar associado à regulação da alimentação (MILLAR, 2003), na modulação das funções da pineal (SERVILI et al., 2010) e de modular o processamento sensorial de estímulos sexuais ou comunicativos (MARUSKA; TRICAS, 2007; MUSKE, 1993; OKA, 1997)

Sabe-se que in vitro o $\mathrm{GnRH} 2$ é um potente estimulador de gonadotropinas, porém in vivo seus níveis hipofisários são baixos (BOSMA et al., 2000). Em mamíferos foi encontrado receptor para o $\mathrm{GnRH} 2$ na hipófise, acreditando que 0 GnRH2 tenha ação nesta glândula (CHEN et al., 1998; MILLAR et al., 2001; NEILL et al., 2001). Em vários teleósteos, o GnRH1 e GnRH2 são encontrados na hipófise e acredita-se que regulem as gonadotropinas e/ou hormônio do crescimento (KING; MILLAR, 1998; SHERWOOD, 1993). Assim como em goldfish, foi visto que as células gonadotrópicas são estimuladas tanto pelo GnRH3 como pelo GnRH2 (KHAKOO et al., 1994; KLAUSEN; CHANG; HABIBI, 2001).

Contudo, estudos relacionados ao $\mathrm{GnRH} 2$ são escassos na literatura, provavelmente pela a falta do seu gene em um dos modelos experimentais mais investigados, o camundongo. Dessa forma, os dados obtidos nesse trabalho para o GnRH2 de lambari são de grande importância cientifica, contribuindo com informações a respeito dessa molécula, além de colaborar com dados a respeito de suas funções.

\subsubsection{GnRH3}

A origem dos neurônios de GnRH3 é no placode olfatório, assim como do GnRH1 (DUBOIS et al., 2002; MUSKE, 1993) e às 26 horas pós-fertilização já é possível observar a sua expressão em zebrafish (GOPINATH; ANDREW TSENG; WHITLOCK, 2004).

O GnRH3 é a forma exclusiva de teleósteos, conhecido anteriormente como $\mathrm{sGnRH}$ (GnRH de salmão). Espécies de teleósteos que apresentam apenas duas 
formas de $\mathrm{GnRH}$, em geral, o $\mathrm{GnRH3}$ ocupa além da região do nervo terminal/telencéfalo ventral, também a região do hipotálamo/área preótica, exercendo assim a função hipofisiotrópica. Existem algumas exceções, como Pantodon buchholzi (Osteoglossiformes; O'NEILL et al, 1998), Anguilla anguilla (Anguilliforme; KING et al, 1990), e Clarias macrocephalus (Siluriformes; NGAMVONGCHON et al., 1992), os quais não possuem o $\mathrm{GnRH3}$, estando presente somente o $\mathrm{GnRH} 1$ e $\mathrm{GnRH} 2$, assim como nas outras espécies de vertebrados. Dessa forma, o $\mathrm{GnRH} 1$ encontra-se na região do telencéfalo ventral/nervo terminal e hipotálamo/área preótica e o $\mathrm{GnRH} 2$ permanece no tegumento do mesencéfalo.

A função do GnRH3 presente no nervo terminal e telencéfalo ventral, ainda não está totalmente esclarecida, alguns autores acreditam que os neurônios de GnRH3 exerçam uma provável função de neuromodulação do comportamento reprodutivo (ABRAHAM et al., 2010; DUBOIS et al., 2002; ONUMA et al., 2005, UCHIDA et al., 2005), além de modularem o processamento de informações visuais e olfatórias da periferia (retina e epitélio olfatório) (EISTHEN et al., 2000; KAWAI; OKA; EISTHEN, 2009; PARKEN; EISTHEN, 2003; ZHANG; DELAY, 2007).

Uma recente análise da sintenia gênica das regiões genômicas que compõem o $\mathrm{GnRH} 3$ de peixes encontrou um arranjo semelhante ao grupo de gene GnRH3 nos genomas de tetrápodes (ROCH; BUSBY; SHERWOOD, 2011), o que indica que o $\mathrm{GnRH} 3$ foi perdido após a divergência das linhagens tetrápodes e peixes (GOPURAPPILLY; OGAWA; PARHAR, 2013; KIM et al. de 2011; TOSTIVINT, 2011)

Assim como o $\mathrm{GnRH2}$, estudos com o GnRH3 não são tão explorados na literatura, dessa forma os dados obtidos nesse trabalho vem a agregar informações importantes a respeito dessa molécula.

\subsubsection{Receptores (GnRHRs)}


Os receptores de $\mathrm{GnRH}$ são clássicos receptores acoplados a proteína $\mathrm{G}$ (GPCRs) com sete domínios transmembrana, importantes em diversas funções fisiológicas (GUILGUR et al., 2006).

A sequência gênica do receptor de $\mathrm{GnRH}$ foi identificado pela primeira vez a partir da linhagem de células gonadotrópicas aT3 de camundongos (MILLAR et al, 2004; TSUTSUMI et al, 1992). A forma de ligação entre o ligante $\mathrm{GnRH}$ e seu receptor é dada por resíduos presentes nas alças extracelulares e no interior das hélices transmembranas, indicando que $0 \mathrm{GnRH}$ entra parcialmente via transmembrana para realizar a ligação com seu receptor (FORFAR; LU, 2011).

Os GnRHRs ortólogos não possuem muita similaridade entre suas sequências, no entanto existem regiões conservadas dentro dos domínios transmembranas e em algumas alças intra e extracelulares, onde existem resíduos específicos que são altamente conservados entre as espécies, que provavelmente estão relacionadas à sua ligação com o ligante (MILLAR, 2005).

A classificação mais recente dos receptores de $\mathrm{GnRH}$ é dada com base em análises filogenéticas, onde são divididos em dois grandes grupos, um chamado de GnRHR tipo I de mamíferos e o outro com todos os receptores ortólogos de GnRH dos outros vertebrados que foi nomeado como GnRHR tipo II, este ainda se subdivide em GnRHR tipo Ila e GnRHR tipo Ilb (ROCH; BUSBY; SHERWOOD, 2011). No entanto, para os receptores de peixes foi realizada uma classificação baseada na sintenia genômica, onde os receptores de $\mathrm{GnRH}$ são divididos em três grandes linhagens que se subdividem em cinco classes, sendo elas: receptores não mamíferos tipo I (GnRHRn1 e GnRHR n1b), receptores não mamíferos tipo II (GnRHRn2) e receptores não mamíferos tipo III (GnRHRn3 e GnRHRn3b) (KIM et al., 2011). Estes receptores já foram identificados em órgãos reprodutivos como gônadas, encéfalo e hipófise (LETHIMONIER et al., 2004) e também em tecidos não reprodutivos, como olhos, rim, brânquias, intestino e fígado, isso para os receptores GnRHRn3 e GnRHRn1, já o $G n R H R n 1 b$ é mais restrito ao sistema nervoso central.

Em alguns teleósteos, existem de quatro a cinco formas de GnRHR em um único individuo (JODO; ANDO; URANO, 2003; MONCAUT et al., 2005). 
No encéfalo, a distribuição dos receptores de GnRH ocorre no telencéfalo, área preótica, hipotálamo ventral, tálamo e mesencéfalo (CHEN; FERNALD, 2006; GONZALEZ MARTINEZ et al., 2004). A maioria desses receptores está envolvida em funções reprodutivas (VOLKOFF; PETER, 1999), no entanto alguns receptores de $\mathrm{GnRH}$ foram encontrados em áreas do encéfalo que estão envolvidas com o controle do apetite e respostas ao estresse (CHANDROO; DUNCAN; MOCCIA, 2004; VOLKOFF et al., 2005).

$\mathrm{Na}$ hipófise a maioria dos receptores de $\mathrm{GnRH}$ é observada na proximal pars distalis, nas células gonadotrópicas (GONZALEZ MARTINEZ et al., 2004; MADIGOU et al., 2000; PARHAR, 2002). Em alguns teleósteos foi vista a presença de GnRHR em outros tipos celulares hipofisários, como nas células prolactínicas, somatolactínicas, tireotrópicas, melonotrópicas, corticotrópicas e somatotrópicas (ILLING et al., 1999; PARHAR; OGAWA; SAKUMA, 2005).

$O$ mecanismo de ativação do receptor GnRHR é semelhante ao que ocorre com os receptores acoplados a proteína $G$, os quais promovem uma mudança conformacional na estrutura do peptídeo ligante, sendo esta essencial para acoplar à proteína G e ocorrer à transdução do sinal (CHEUNG; HEARN, 2002; ILLING et al., 1999; LEVAVI SIVAN; AVITAN, 2005).

Os GnRHRs e os típicos receptores acoplados à proteína $G$ sofrem dessensibilização e a internalização incluindo a fosforilação do receptor, depois de ser ativado (MCARDLE et al., 2002). Esta fosforilação estabiliza a associação de GPCR com a $\beta$-arrestina, o que impede a ativação efetora e age como um adaptador, marcando os GPCRs sensibilizados para internalização (FERGUSON, 2001) por endocitose. No entanto, o receptor de $\mathrm{GnRH}$ de mamífero tipo I, não possui a alça intracelular do C-terminal, não sendo, portanto um característico receptor acoplado à proteína $G$ e esta ausência causa deficiência na dessensibilização durante ativação do ligante, comprometendo a internalização deste receptor (MCARDLE; DAVIDSON; WILLARS, 1999; MCARDLE et al., 2002).

A ligação do $\mathrm{GnRH}$ ao receptor ativa a fosfolipase C (PLC) gerando assim inositol trifosfatado (IP3) e diacylglicerol (DAG), o qual mobiliza $\mathrm{Ca}^{2+}$ para o meio intracelular ativando assim a proteína cinase $\mathrm{C}(\mathrm{PKC})$. A via de $\mathrm{PKC}^{\mathrm{e}} \mathrm{Ca}^{2+}$ está 
envolvida na expressão das subunidades de gonadotropinas, enquanto a secreção das gonadotropinas são principalmente mediadas pelo aumento de cálcio citoplasmático induzido pelo GnRH por meio da calmodulina (CaM) (LEVAVISIVAN; AVITAN, 2005).

Em tilápia, o GnRH regula a transcrição do hormônio glicoproteico $\beta \mathrm{LH}$ por meio da via PKC-ERK (proteína cinase C - cinase regulatória de sinais extracelulares) já a transcrição do $\beta F S H$ é independente de ERK e sofre ação direta da regulação de PKA-cAMP (proteína cinase A - adenosina 3', 5'monofosfato cíclico) ou por outras cascatas de MAPK (Proteína-cinases ativadas por mitógenos) (GUR et al., 2002).

A regulação dos GnRHRs em peixes é pouco estudada, mas é visto que os genes dos GnRHRs são sensíveis a esteróides sexuais como visto em mamíferos (HAPGOOD et al., 2005), além de ser influenciado por fatores ambientais e nutricionais, mas ainda via níveis de esteróides sexuais (HILDAHL et al., 2013). Em tilápia os níveis de mRNA de GnRHR3 são mais altos em fêmeas vitelogênicas que em machos maduros, provavelmente devido aos altos níveis de 17ß-estradiol (LEVAVI SIVAN et al., 2004).

Foi visto também que o peptídeo GnRH controla a expressão dos seus receptores na hipófise (MCARDLE et al., 1987; UEMURA et al., 1992). $\mathrm{Na}$ linhagem de células gonadotrópicas aT3-1 de camundongos, baixo níveis de GnRH estimulavam em até $50 \%$ a síntese dos GnRHRs (TSUTSUMI; LAWS; SEALFON,1993), e altos níveis de GnRH inibiam a expressão dos receptores (MCARDLE et al., 1995). Já em peixes, Epinephelus coioides, foi visto que o GnRH3 estimula a síntese do GnRHRn1, enquanto o GnRH2 e GnRH1 inibem a síntese do mesmo receptor (HSIEH et al., 2007).

Em relação à afinidade dos receptores para o ligante específico, existem poucos estudos em peixes, mas foi demostrado que os receptores de $\mathrm{GnRH}$ se ligam com diferentes afinidades às variantes de $\mathrm{GnRH}$, e isto ocorre de forma espécie especifico (BOGERD et al., 2002; ROBISON et al., 2001). Em Dicentrarchus labrax, o receptor mais expresso na hipófise é GnRHRn1, sendo este provavelmente o que medeia as respostas das células gonadotrópicas 
(GONZALEZ MARTINEZ et al., 2004). Outro estudo ainda com Dicentrarchus labrax analisando a afinidade dos receptores GnRHRn2, mostrou que o GnRHRn2b apresenta afinidade somente para o $G n R H 2$, já o $G n R H R n 2$ mostrou afinidade para o $\mathrm{GnRH} 2$ e $\mathrm{GnRH} 3$ sendo o $\mathrm{GnRH} 1$ o menos eficiente na ligação com estes receptores (SERVILI et al., 2010).

De maneira geral, foi observado que o GnRH2 mostra maior afinidade com os diferentes tipos de receptores quando comparado com as outras formas de GnRH (KAH et al., 2007; LETHIMONIER et al., 2004 ; MILLAR, 2003).

\subsubsection{Aspectos evolutivos}

O GnRH é considerado um marcador de estudos em evolução, já que está presente em tecido neural desde invertebrados até em vertebrados, a partir de peixes agnathas (SHERWOOD et al., 1986), indo até mamíferos (KASTEN et al., 1996; WHITE et al., 1998). Este quadro indica que o $\mathrm{GnRH}$ é bem antigo, exercendo suas funções perfeitamente, e deixa claro a sua conservação durante a evolução.

Em vertebrados, são encontradas duas formas parálogas de GnRH em um único individuo, porém, em alguns teleósteos podem ser encontradas até três formas, variando na expressão e na localização no encéfalo. A presença de mais de uma forma paráloga de $\mathrm{GnRH}$ em vertebrados é resultante da duplicação de um gene ancestral de $\mathrm{GnRH}$, os quais foram sofrendo subfuncionalizações após estes eventos de duplicação. Contudo algumas das formas do $\mathrm{GnRH}$ foram perdidas em certas linhagens de vertebrados ao longo do tempo. Nos casos em que uma das formas parálogas do $\mathrm{GnRH}$ foi perdida, provavelmente houve uma compensação funcional da forma paráloga restante (OKUBO; NAGAHAMA, 2008).

A presença do $\mathrm{GnRH}$ em cnidários, considerado o primeiro animal com neurônios e sinapses verdadeiras (ANCTIL, 2000), leva-nos a pensar que possivelmente a família do $\mathrm{GnRH}$ tenha se originado por volta de 600 milhões de anos atrás, possivelmente antes da explosão do Cambriano, anterior a divergência entre protostomados e deuterostomados (TSAI; ZHANG, 2008). 
Todos os genes codificantes das diferentes formas de $\mathrm{GnRH}$ em vertebrados têm a mesma arquitetura de 4 exons separados por 3 introns, sendo tal estrutura altamente conservada durante a evolução, apesar de mudanças no tamanho e sequência de exons e introns (KAVANAUGH; NOZAKI; SOWER, 2008).

Em cada gene, o exon 1 transcreve a região não codificante $5^{\prime}$ (UTR); os exons 2 e 3 codificam o peptídeo sinal, o GnRH decapeptídeo, o lado de clivagem proteolítica e o peptídeo associado ao $\mathrm{GnRH}$ (GAP); e o exon 4 codifica o carboxi terminal da GAP e a região não codificante 3' (UTR) (KAVANAUGH; NOZAKI; SOWER, 2008). Comparações entre os cDNAs precursores codificantes de distintos membros da família de GnRH mostram uma completa conservação do lado de clivagem proteolítico e alta homologia dos decapeptídeos, mas grandes divergências na região da GAP, logo existe uma maior conservação do exon 2 e maior divergência entre os exons 1, 3 e 4 (KING; MILLAR, 1998; YU et al., 1997).

Dentre todas as formas da molécula de preproGnRH, a mais conservada é o preproGnRH2, que está presente em quase todas as classes de vertebrados (DUBOIS et al., 2002). Já a forma hipofisiotrópica (preproGnRH1) e a forma exclusiva de teleósteos (preproGnRH3), possuem uma grande variação na sua sequência, bem como na estrutura dos aminoácidos (MONTANER et al., 2001). No entanto, são necessários mais estudos sobre o $\mathrm{GnRH}$, uma vez que novas formas estão sendo descobertas, restando ainda examinar $\mathrm{GnRHs}$ de muitas espécies, incluindo os da ordem Characiformes.

\subsection{Gonadotropinas}

As gonadotropinas são hormônios glicoproteicos, sintetizados nas células gonadotrópicas da adeno-hipófise, mais precisamente na região da proximal pars distalis em teleósteos. Tais hormônios participam ativamente do ciclo reprodutivo de vertebrados (SWANSON; DICKEY; CAMPBELL, 2003).

Até a década de 1980, acreditava-se que teleósteos possuíam uma única gonadotropina (GtH) e esta exercia todas as funções fisiológicas como, o controle 
da produção de esteróides, em fêmeas na vitelogênese e na maturação final do oócito final, e em machos na espermatogênese e na espermiação (BURZAWA GERARD, 1982). No entanto, este conceito foi mudado no final dos anos oitenta após a descoberta feita por KAWAUCHI e colaboradores (1989) de duas gonadotropinas distintas em salmão, GtH I e II, as quais correspondem atualmente ao $\mathrm{FSH}$ e LH respectivamente.

A maioria das espécies de vertebrados, exceto agnathas, expressam dois subtipos de gonadotropinas, o hormônio folículo-estimulante (FSH) e o hormônio luteinizante $(\mathrm{LH})$. Estas gonadotropinas são compostas por duas subunidades unidas por ligações não covalentes, sendo uma unidade comum ao $\mathrm{FSH}$ e $\mathrm{LH}$, chamada de aGTH, e uma subunidade específica para cada hormônio, chamada de $\beta F S H$ e $\beta L H$, a qual vai conferir a especificidade biológica (KANDA; OKUBO; OKA, 2011).

O controle da expressão de cada subunidade de gonadotropina é dependente de vários hormônios, dentre eles os esteróides sexuais, onde foi observado na região promotora do $\beta F S H$ e do $\beta L H$ porções responsivas ao estrógeno, andrógeno e glicocorticoides (GOLAN; BIRAN; LEVAVI-SIVAN, 2014), no entanto, na maioria dos casos a resposta do $\beta$ LH e do aGTH são similares, já o $\beta F S H$ difere (YARON et al., 2003).

Em tetrápodes, o FSH e o LH são expressos na mesma célula (PINELLI et al., 1996), diferentemente de teleósteos, onde cada tipo de gonadotropina é expresso por uma célula diferente, sendo o $\beta F S H$ expresso na dorsal proximal pars distalis e o $\beta$ LH na ventral proximal pars distalis (GOLAN; BIRAN; LEVAVISIVAN, 2014; KANDA; OKUBO; OKA, 2011; YARON et al., 2003).

Quanto à expressão dos receptores de gonadotropinas nas gônadas de teleósteos, em machos, os receptores para FSH são expressos nas células de Sertoli, e os receptores de LH e FSH nas células de Leydig. Em fêmeas, os receptores de $\mathrm{LH}$ e FSH estão presentes, principalmente, nas células da teca (NAGAHAMA, 1997).

Em mamíferos, o FSH e o LH interagem de maneira altamente específica com seus receptores, apresentando pouca sobreposição de atividade biológica em 
concentrações fisiológicas desses hormônios (HUHTANIEMI; THEMMEN, 2005). Já em peixes, o FSHR mostrou uma preferência por FSH, mas também foi ativada pelo LH. No entanto, essa ativação cruzada dos FSHR requer concentrações elevadas de LH e pode ser limitado aos períodos com níveis plasmáticos de pico de LH, tais como durante a época de desova; porém, o LHR é considerado específico (GARCIA-LOPEZ et al., 2009; KAZETO et al, 2008; SAMPATH KUMAR; IJIRI; TRANT, 2000).

Em geral, em teleósteos assim como em outros tetrápodes acredita-se que o FSH exerça sua função durante as fases iniciais da gametogênese, para os dois sexos, sendo um potente indutor da síntese de estrógenos pelo ovário (LEVAVI SIVAN et al., 2010; YARON et al., 2003), enquanto o LH regula as fases finais da gametogênese incluindo a maturação final do oócito e do espermatozoide, assim como a ovulação e espermiação, sendo importante na síntese de estrógenos, andrógenos e esteróide indutor da maturação (MIS), como principalmente o 17a,20ß-dihydroxy-4-pregnen-3-one (LEVAVI-SIVAN et al., 2010; YARON et al., 2003).

No entanto, em teleósteos, esta afirmação esta bem estabelecida para salmonídeos, os quais possuem desenvolvimento sincrônico, já para outras espécies, as quais apresentam uma diversidade de estratégias reprodutivas, sendo uma delas o desenvolvimento assincrônico, onde em uma única fase do desenvolvimento gonadal apresenta diversos estágios de desenvolvimento celular, o padrão de secreção assim como das funções fisiológicas das duas gonadotropinas ainda não estão bem definidos.

Em Anguilla japonica, foi observado o mesmo padrão para salmonídeos, onde o FSH atua na proliferação espermatogonial, enquanto LH está associado à maturação do espermatozoide e espermiação (MIURA et al, 1991; OHTA et al, 2007).

Em algumas espécies é visto que o FSH está associado ao período de vitelogênese e proliferação espermatogonial, porém surge novamente durante a maturação do oócito e do espermatozoide, assim como na ovulação e 
espermiação, juntamente com o pico do $\mathrm{LH}$, sendo o LH predominante nesta segunda fase (BRETON et al., 1998; MITSUO et al., 2012).

Além da fase do ciclo reprodutivo, foi observado que a hora do dia interfere na expressão das gonadotropinas, sendo um mecanismo conservado ao longo da escala evolutiva. Em mulheres o pico de LH ocorre no inicio da manhã (KERDELHUÉ et al.,2002). Em roedores que são noturnos, o pico de LH é no seu período de atividade, por volta da hora que não tem mais luz (BRONSON; VOM SAAL, 1979), em medaka é visto que o pico do $\beta L H$ assim como do $\beta F S H$ é às 5 horas da manhã (KARIGO et al., 2012).

Do mesmo modo que mecanismo de expressão se apresentou de forma conservada, a sintenia das subunidades aGTH e $\beta F S H$ também se mantiveram entre diferentes classes de vertebrados, no entanto a subunidade $\beta \mathrm{LH}$ não mostrou conservação da sintenia entre os teleósteos e tetrápodes (KANDA; OKUBO; OKA, 2011).

Em relação à similaridade gênica, foi visto que a subunidade aGTH é a que apresenta o mais alto nível de conservação (QUÉRAT, 1994). Em tetrápodes a subunidade $\beta F S H$ mostra mais similaridade quando comparado com a subunidade $\beta L H$, a qual mostra uma acelerada taxa de evolução (WALLIS, 2001). Por outro lado, em peixes a subunidade $\beta F S H$ são mais divergentes que as $\beta L H$ (com uma media de similaridade de $53 \%$ e $67 \%$, respectivamente) (HASSIN; ELIZUR; ZOHAR, 1995; KATO et al., 1993;).

Diante de tudo é visto que as gonadotropinas estão totalmente envolvidas na reprodução de vertebrados, sendo estimuladas principalmente pelo $\mathrm{GnRH}$, mas também sofrem o controle dos esteróides sexuais, formando uma rede endócrina coordenando a reprodução.

\subsection{Esteróides}

Os esteróides sexuais (estrógenos, andrógenos e progestágenos) regulam genes e proteínas envolvidos em múltiplas respostas e funções, tais como o crescimento de osso, metabolismo, o desenvolvimento de características sexuais 
secundárias, comportamento sexual, desenvolvimento gonadal, maturação, espermatogênese e oogênese, neuroplasticidade e cognição.

A biossíntese dos esteróides sexuais é derivada a partir da molécula de colesterol que por meio de diversas reações enzimáticas dá origem aos diferentes esteróides (YOUNG et al., 2005).

Algumas das principais enzimas envolvidas neste processo são: as enzimas do citocromo P450 (CYPs), incluindo a CYP11a (enzima de clivagem da cadeia lateral do colesterol), a qual a partir do colesterol dá origem a pregnenolona, a enzima CYP19 (aromatase) responsável pela aromatização de andrógenos em estrógenos, existindo duas formas dessa enzima, a Cyp19a1 expressa principalmente nas gônadas e a Cyp19a2 expressa principalmente no

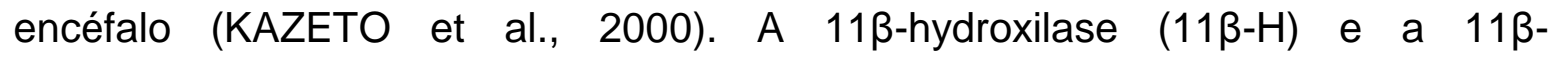
hidroxiesteróide desidrogenase (11ß-HSD) são duas enzimas responsáveis nos passos de conversão da testosterona em 11-cetotestosterona (11-KT); a enzima

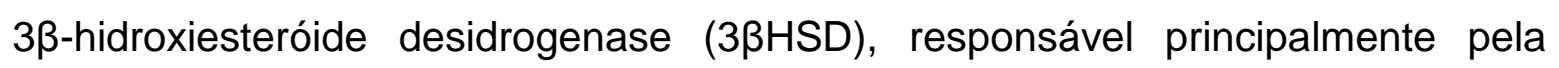
conversão de pregnenolona em progesterona e a enzima $20 \beta$-hidroxiesteróide desidrogenase (20ßHSD) está associada à reação enzimática para a conversão

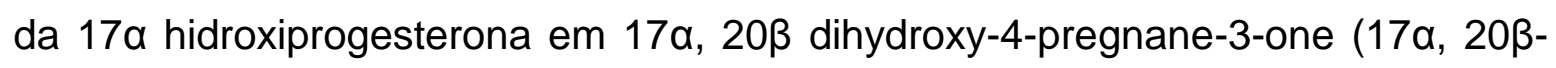
DP) (BORG, 1994; MARTYNIUK; BISSEGGER; LANGLOIS, 2013; YOUNG et al., 2005).

Além das anteriores, existem as enzimas 3-hydroxy-3-methylglutarylcoenzima $A$ reductase (HMGR) e a proteína reguladora aguda esteroidogênica (StAR), as quais exercem um papel fundamental na regulação da disponibilidade do colesterol para a biossíntese dos esteróides, sendo a HMGR uma enzima limitante da taxa de síntese do colesterol em células esteroidogênicas, enquanto a StAR proporciona colesterol do exterior para o interior da membrana mitocondrial onde começa a esteroidogênese (BAUER et al., 2000;. GOLDSTEIN; BROWN, 1990; STOCCO, 2001).

Algumas particularidades em relação aos tipos de esteróides existem em teleósteos, como a 11-cetotestosterona (11-KT) a qual representa o principal andrógeno, quando na maioria dos vertebrados é a testosterona, e a 17a, 20 


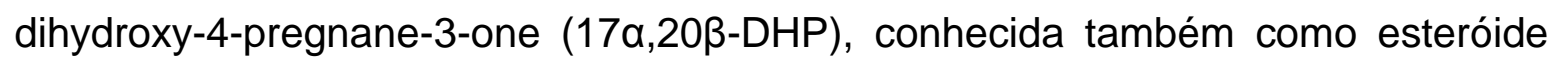
indutor da maturação (MIS) é a principal progesterona para algumas espécies de teleósteos, enquanto para outras é o 17a, 20ß, 21 -trihydroxy-4-pregnane-3-one (20ß-S), alguns estudos mostram ainda que existem espécies onde estes dois progestágenos atuam concomitantemente (KING; THOMAS; SULLIVAN, 1994; KING et al., 1994; KING; BERLINSKY; SULLIVAN, 1995; OHTA; MATSUYAMA, 2002).

Os principais locais de expressão dos hormônios sexuais são nas células da granulosa (folicular) e da teca em ovários, e nas células de Leydig nos testículos (THOMAS, 2008).

Os efeitos biológicos dos esteróides sexuais se dão por meio de sua ligação a seus receptores nucleares, funcionando como fatores de transcrição, regulando a expressão gênica.

$\mathrm{Na}$ maioria dos vertebrados, existem dois receptores de estrógenos, ERa e ERß, em peixes existe um terceiro subtipo, ERß2 ou ERy (HAWKINS et al., 2000; MENUET et al., 2002), enquanto para os andrógenos foi descrito apenas um tipo de receptor (AR) (YOKOYAMA et al., 2009).

Os esteróides sexuais também podem se ligar a receptores de membrana que medeiam efeitos não-genômicos. Uma ação não-genômica bem caracterizada dos esteróides sexuais é realizada pela progesterona, a qual se liga a receptores de membrana regulando assim a maturação do oócito em peixes e anfíbios (THOMAS, 2008, 2012).

Sabe-se da participação dos esteróides em várias funções do organismo, incluindo a reprodução, onde atuam principalmente no desenvolvimento e maturação das gônadas e juntamente no controle dos hormônios hipofisários e hipotalâmicos também envolvidos nos processos reprodutivos, no entanto, em peixes, a maneira a qual os esteróides atuam nesse controle é dependente da espécie, do gênero sexual, da estação anual e do estágio de maturação gonadal.

De maneira geral, tem-se visto na literatura que os esteróides sexuais realizam um feedback positivo principalmente para o $\beta$ LH (HUGGARD NELSON et al., 2002; KANDA; OKUBO; OKA, 2011; LO; CHANG, 1998; ZHANG et al., 2014) 
porém, em algumas espécies, o estímulo também ocorre para o $\beta F S H$ (BORG et al., 1998, HUGGARD NELSON et al., 2002).

O principal esteróide envolvido diretamente neste controle dos hormônios hipotalâmicos e hipofisários é o $17 \beta$ estradiol, já a testosterona atua de forma indireta por meio da sua aromatização em $17 \beta$ estradiol na maioria das espécies estudadas (MELAMED et al, 1998; REBERS et al, 2000; ZHANG et al., 2014).

Ao longo do ciclo reprodutivo tanto os níveis, como os tipos de esteróides sexuais são diferentes e variam de acordo com as necessidades do desenvolvimento gamético e do sexo do animal.

Em fêmeas, normalmente os níveis de testosterona e de estradiol aumentam nos estádios pré-vitelogênicos e vitelogênico e diminuem com a maturação do oócito, ou seja, com a quebra da vesícula germinativa (LANGE; HARTEL; MEYER, 2003). Já durante a maturação final e desova são os níveis do MIS que predominam, sendo compostos derivados da progesterona e específicos da espécie. Ao se ligarem a receptores específicos de membrana dos oócitos, inibem a ligação da adenilato ciclase ao oócito, resultando na atividade reduzida da proteína cinase dependente de AMP cíclico, isso induz a ativação do fator promotor da maturação (MPF) via Cdc25, e desse modo, a quebra da vesícula germinativa e a retomada da divisão meiótica I (NAGAHAMA; YAMASHITA, 2008).

Em machos, os níveis plasmáticos de $\mathrm{E}_{2}$ sofrem uma elevação transitória no início do ciclo reprodutivo (GOMEZ et al., 1999), sendo importante para a renovação das espermatogônias tronco (MIURA et al.,1999). Os andrógenos (testosterona e 11-cetotestosterona) aumentam gradualmente à medida que a espermatogênese se encaminha e na maioria das espécies diminui na espermiação, sendo eficaz na proliferação espermatogonial, na formação dos espermatócito ou na maturação (BORG, 1994; NAGAHAMA, 1994). E os níveis plasmáticos do MIS tem seu pico durante a espermiação (KUSAKABE et al., 2006), e além de estimular a espermiação, este hormônio está envolvido no aumento da produção de sêmen (BAYNES; SCOTT, 1985; YUEH; CHANG, 1997), e estimula a motilidade dos espermatozóides (MIURA et al, 1992; TUBBS; THOMAS, 2008). 
Dessa forma, os esteróides sexuais atuam ativamente no processo reprodutivo, participando de todo o processo de gametogênese, assim como regulando os hormônios hipotalâmicos e hipofisários.

\subsection{Oogênese}

$\mathrm{Na}$ maioria dos teleósteos, os ovários são estruturas pares, suspensos dorsalmente dentro da cavidade celomática por um tecido conjuntivo e apresentam-se geralmente como estruturas saculares, sendo compostas por lamelas e um lúmen (GRIER; URIBE ARANZABAL; PATIÑO, 2009).

As lamelas são formadas por um epitélio germinativo e um estroma subjacente a este epitélio; estes dois compartimentos são separados por uma membrana basal, na qual o epitélio germinativo está apoiado (GRIER; URIBE ARANZABAL; PATIÑO, 2009).

O epitélio germinativo é composto por células germinativas e células somáticas. Já o estroma, é composto por células do tecido conjuntivo como as células mesenquimais indiferenciadas, fibroblastos, granulócitos e por fibras colágenas e vasos sanguíneos (GRIER; URIBE ARANZABAL; PATIÑO, 2009).

A unidade funcional do ovário é chamada de folículo ovariano, o qual é composto pelo oócito e pelas células foliculares. Em teleósteos, o folículo está rodeado por células da teca, sendo toda a estrutura chamada de complexo folículo ovariano, composto pelo oócito, células foliculares, ou granulosas, membrana basal e células da teca. Na expulsão do oócito no processo de ovulação, a estrutura folicular se mantem e é denominada de complexo pós-ovulatório, composto por células foliculares, membrana basal e células da teca (GRIER, 2000).

No início do crescimento primário dos oócitos, o oócito e as células foliculares começam a se separar, formando um espaço entre elas (LE MENN et al. 2007), microvilosidades do oócito e das células foliculares se prolongam para dentro deste espaço (BEGOVAC; WALLACE, 1988; LE MENN; CERDÀ; BABIN, 2007) criando então uma comunicação bidirecional entre as células foliculares e 0 
oócito por meio das junções gap presentes nas microvilosidades dessas células (WANG; GE, 2004).

O processo de desenvolvimento do oócito, desde oogônia até um oócito capaz de ser fertilizado é denominado de oogênese, a qual é dividida em etapas, e se inicia com a proliferação das oogônias, que em seguida entram em meiose tornando-se oócitos e encerra-se com a desova. Após a proliferação e entrada na meiose, progressivas mudanças morfológicas são observadas no núcleo e no citoplasma dos oócitos, e essas mudanças são usadas para a classificação das fases da oogênese (LUBZENS et al., 2010).

Numerosas classificações para o desenvolvimento da oogênese em teleósteos têm sido propostas, porém, como já foi comentado por DODD em 1986 a terminologia ovariana é confusa. Brown Peterson e colaboradores em 2011 fizeram um apanhado de diversas nomenclaturas existentes e propuseram uma classificação mais simplificada com base nas terminologias já descritas, dessa maneira utilizaremos a forma simplificada para a descrição dos estágios de desenvolvimento ovariano.

Primeiramente, o termo fase é usado para etapas do ciclo reprodutivo enquanto o termo estágio é utilizado para o desenvolvimento gamético, diante disso os estágios de desenvolvimento gamético segundo BROWN PETERSON e colaboradores (2011) são: oogônia, alvéolo cortical, oócitos primários, oócitos vitelogênicos, os quais são divididos em vitelogênico 1, 2 e 3 (Vtg1, Vtg2 e Vtg3), e oócitos maduros, caracterizados pela quebra da vesícula germinativa.

Mais detalhadamente os estágios de desenvolvimento oocitário incluem a formação de células germinativas primordiais caracterizadas pela presença de nuages (estruturas eletrondensas associadas a mitocôndrias, RNAs e proteínas), além de apresentarem um tamanho relativamente grande, assim como um núcleo o qual apresenta de um a dois nucléolos (BRAAT et al., 1999; LYMAN GINGERICH; LE MENN et al.,2007; PELEGRI, 2007).

Posteriormente as células germinativas dão origem às oogônias e subsequentemente, à sua diferenciação em oócitos primários, onde ocorre a endocitose de lipídeos e vitelogenina, sendo o estágio inicial do oócito e da 
foliculogênese (formação das células foliculares), tendo o crescimento primário um desenvolvimento independente de gonadotropinas (BILLARD, 1992).

O evento subsequente é caracterizado pelo aumento do tamanho do oócito e pela presença de alvéolos corticais na periferia do oócito. Este estágio é conhecido como oócito pré-vitelogênico (SELMAN et al., 1993) sendo esta fase dependente de gonadotropinas (SWANSON; DICKEY; CAMPBELL, 2003) e caracterizada pelo início da meiose.

Posteriormente inicia-se a vitelogênese, caracterizada pelo aumento do oócito devido ao acumulo de reservas nutricionais necessárias para o desenvolvimento do embrião. No final deste processo, o oócito torna-se competente para ser fertilizado, contendo proteínas, mRNAs maternos, lipídios, carboidratos, vitaminas e hormônios que são importantes para 0 bom desenvolvimento do embrião. O crescimento maciço do folículo ovariano ocorre durante a captação de lipídios e de proteína do plasma pelo oócito (BROOKS; TYLER; SUMPTER, 1997; LE MENN et al., 2007; WALLACE; SELMAN, 1981, 1990). Durante este período o oócito permanece em fase meiótica, mais precisamente no final da prófase I, na fase diplóteno (LUBZENS et al., 2010).

O principal componente no vitelo são as vitelogeninas que são glicolipofosfoproteínas encontradas no sangue de fêmeas de todas as espécies de vertebrados ovíparos durante vitelogênese. Elas são sintetizadas principalmente no fígado (BABIN et al, 2007) e atingem o oócito por meio da passagem dos capilares presentes na camada da teca atingindo então a camada folicular, chegando à superfície do oócito por meio de canais da zona radiata, e sendo incorporadas ao oócito por endocitose (WALLACE; SELMAN, 1990).

Os processos da maturação são caracterizados pela redução ou a parada da endocitose, por retomar a meiose, e pela quebra da vesícula germinativa (GVBD) (PATIÑO; SULLIVAN, 2002).

Após a retomada da meiose, o oócito em metáfase II é liberado de seu folículo, na cavidade do ovário ou na cavidade celomática dependendo da espécie, este processo é conhecido como ovulação (LUBZENS et al., 2010). E para que ocorra a separação dos oócitos da camada folicular é necessário que 
haja uma retração adequada das microvilosidades dos oócitos intimamente ligadas às células da granulosa durante vitelogênese, rompendo junções de adesão célula-célula e junções comunicantes entre o oócito e as células foliculares (CERDÀ et al., 1999).

Quando folículos ovarianos são recrutados para iniciar vitelogênese, mas não conseguem completar a maturação e ovulação ocorre a atresia, que é um fenômeno comum em ovários de vertebrados, tanto em condições naturais como em experimentais (SAIDAPUR, 1978), sendo este mecanismo um processo altamente regulado e essencial para a manutenção do equilíbrio no ovário (Krysko et al., 2008).

Em teleósteos, numerosos fatores têm sido descrito como causadores do aumento de atresia folicular, tais como fome, mudanças de temperatura, estresse e tratamentos hormonais inadequados (GURAYA, 1986). Em cativeiro, a atresia é mais frequente em oócitos vitelogênicos, embora também possa ocorrer em oócitos pré-vitelogênicos (GURAYA, 1986; MIRANDA et al., 1999; RIZZO; BAZZOLI,1995).

O processo de atresia e reabsorção de folículos ovarianos em peixes são precedidos por alterações morfológicas marcantes, tanto no oócito como nas células foliculares. Os primeiros sinais morfológicos de atresia são desintegração do núcleo do oócito e de organelas citoplasmática, seguido pela fragmentação da zona pelúcida e hipertrofia das células do folículo (SAIDAPUR, 1978; MIRANDA et al, 1999).

Com relação às fases do ciclo reprodutivo, existe a fase imatura, a qual não se considera que o animal esteja inserido no ciclo reprodutivo, onde a proliferação dos gametas e crescimento são independentes de gonadotropinas, estando presentes principalmente oogônias, e oócitos iniciais. A partir do momento que o peixe entra no ciclo reprodutivo, o crescimento gonadal e o desenvolvimento gamético se torna dependente de gonadotropina, ou seja, o peixe atinge a maturidade sexual e entra na fase de desenvolvimento. Uma vez atingindo a maturidade sexual o animal nunca mais sairá do ciclo reprodutivo e retornará a fase imaturo. A fase de desenvolvimento é considerada uma preparação para a 
fase reprodutiva e é caracterizada com o surgimento dos oócitos alvéolo cortical (CA), VTg1 e 2, mas não de Vtg3 (BROWN PETERSON et al., 2011).

A fase seguinte, conhecida como fase aptos a se reproduzir é definida pelo desenvolvimento avançado dos gametas, tal que os oócitos são capazes de receber sinais hormonais para sua maturação, sendo os peixes capazes de se reproduzirem (BROWN PETERSON et al., 2011).

O final do ciclo reprodutivo é indicado pela fase de regressão, o qual é caracterizado por: atresia, complexos pós-ovulatórios e poucos oócitos Vtg2 e Vtg3 saudáveis. Os peixes permanecem na fase de regressão por um período de tempo relativamente curto e depois passam para a fase de regeneração. (BROWN PETERSON et al., 2011).

A fase de regeneração, os gametas sofrem intensa proliferação e crescimento independente de gonadotropina, em preparação para o próximo ciclo reprodutivo. Os peixes nesta fase são sexualmente maduros, mas reprodutivamente inativos. Características da fase de regeneração incluem oócitos iniciais, fase final de atresia, e uma parede de ovário mais grosso do que é visto em juvenis (BROWN PETERSON et al., 2011).

Existem diversas estratégias reprodutivas em teleósteos devido à diversidade entre as espécies. Uma dessas estratégias é em relação ao desenvolvimento gamético, sendo as espécies que apresentam uma única onda de desenvolvimento oogênico, como espécies semélparas, leva a um padrão sincrônico de desenvolvimento ovariano, onde todos os oócitos presentes no ovário estão no mesmo estágio de desenvolvimento. Muitas espécies de clima temperado com períodos reprodutivos curtos e com indivíduos que se reproduzem uma vez ao ano, exibem um padrão de desenvolvimento ovariano do tipo sincrônico em grupo, com pelo menos dois tipos de estágios das células germinativas. $\mathrm{E}$ as espécies com período reprodutivo prolongado, as quais se reproduzem mais de uma vez em cada período reprodutivo apresentam um desenvolvimento assincrônico, onde estágios contínuos da oogênese estão presentes simultaneamente nas gônadas (MYLONAS; ZOHAR, 2007) 
Enfim, as classificações do desenvolvimento ovariano em fases e estágios é algo bastante artificial já que o desenvolvimento dos oócitos é um processo dinâmico e é difícil identificar o início ou o final de cada evento.

\subsection{Espermatogênese}

$\mathrm{Na}$ maioria dos teleósteos, os testículos são estruturas pares, suspensos dorsalmente dentro da cavidade celomática por tecido conjuntivo, suas formas variam de acordo com a espécie, mas normalmente apresentam se como estruturas cilíndricas.

Em todos os vertebrados, o testículo é composto de dois compartimentos principais, o intersticial e o germinativo. O compartimento intersticial contém as células de Leydig, vasos sanguíneos e linfáticos e tecido conjuntivo (KOULISH; KRAMER; GRIER, 2002). O compartimento germinativo é composto por uma membrana basal, células de Sertoli, que são células somáticas, e as células germinativas, que são encontrados em diferentes estágios de desenvolvimento (GRIER, 1993).

As células germinativas apresentam interação direta e contínua com as células de Sertoli, de modo que o número de células de Sertoli determina a capacidade espermatogênica de um testículo e é um alvo importante dos sistemas de sinalização de regulação da espermatogênese (MATTA et al., 2002).

Em répteis, aves e mamíferos, as células de Sertoli dão suporte, ao mesmo tempo, a diferentes estágios de desenvolvimento de células germinativas. Por exemplo, em contato com a base da célula de Sertoli estão as espermatogônias, enquanto nas partes laterais estão em contato os espermatócitos e na parte apical estão as espermátides (SCHULZ et al., 2010).

Por outro lado em peixes e anfíbios a espermatogênese é do tipo cística (CALLARD, 1996), onde as células de Sertoli formam cistos que envolvem clones provenientes de uma única espermatogônia, portanto, o desenvolvimento das células germinativas dentro desse cisto se dá de forma sincrônica estando todos no mesmo estágio de desenvolvimento. Assim, a unidade funcional básica do 
epitélio germinativo em peixes é um cisto espermatogênico formado por um grupo dinâmico de células de Sertoli circundando e nutrindo o desenvolvimento de forma sincrônica os clones de células germinativas (SCHULZ et al., 2005).

Dois tipos de arranjos espaciais foram descritos na literatura para os testículos teleósteos com base na distribuição de espermatogônias dentro do compartimento germinativo (GRIER, 1981). No primeiro tipo, conhecido como distribuição espermatogonial restrito, as regiões distais do compartimento germinativo, próximo à túnica albugínea, são ocupados pelas células de Sertoli envolvendo espermatogônias indiferenciadas. À medida que as células se dividem e entram em meiose, os cistos migram para a região dos ductos espermáticos localizados centralmente no testículo, onde ocorre espermiação, ou seja, os cistos se abrem para liberar espermatozóides (PARENTI; GRIER, 2004). No segundo tipo, conhecido como distribuição espermatogônial irrestrito, as espermatogônias estão distribuídas ao longo de todo o compartimento germinativo do testículo. Os cistos não migram ou se deslocam durante o seu desenvolvimento (GRIER, 1981).

$O$ processo em que espermatogônias diploides se proliferam e se diferenciam para formar espermatozóides maduros recebe 0 nome de espermatogênese. A duração deste processo é geralmente menor em peixes do que em mamíferos e também é influenciada pela água temperatura assim como fatores ambientais (NÓBREGA; BATLOUNI; FRANÇA, 2009).

Em princípio, o processo de espermatogênese é conservado entre os vertebrados e morfo-funcionalmente pode ser dividido em três fases distintas: a fase mitótica ou espermatogônial com as diferentes gerações de espermatogônias (ou seja, espermatogônias não diferenciadas incluindo as células tronco, e espermatogônias diferenciadas ou em diferenciação); a fase meiótica com o espermatócitos primários e secundários; e a fase espermiogênica com as espermátides haplóides saindo da meiose e se diferenciando em espermatozóides (NÓBREGA; BATLOUNI; FRANÇA, 2009).

As células-tronco espermatogonial, ou espermatogônias indiferenciadas, por meio de mitose dão origem a células semelhantes por processo de auto renovação, ou, então originam as espermatogônias diferenciadas, que ainda 
partilham algumas características morfológicas com as indiferenciadas, mas com potencial de auto renovação reduzido. Estas espermatogônias diferenciadas, ainda por mitose, dão origem às espermatogônias do tipo $B$, as quais estão comprometidas com a maturação e diferenciação em espermatozoides e geralmente apresentam várias gerações (LEAL et al., 2009). Geralmente o numero de divisões mitóticas que precede a entrada em meiose é espécie especifico em peixes (ANDO et al. 2000).

Após a mitose final, as espermatogônias do tipo B se diferenciam em espermatócitos primário os quais após a primeira divisão meiótica dão origem aos espermatócitos secundários que completam a segunda divisão meiótica originando as espermátides que por diferenciação celular dará origem aos espermatozóides (SCHULZ et al., 2010).

O processo de diferenciação de espermátides em espermatozóides é denominado de espermiogênese, o qual consiste em uma série de mudanças morfológicas como desenvolvimento de flagelo, compactação do DNA, eliminação de organelas e citoplasma, e rearranjo celular das organelas (JAMIESON, 1991).

No final da espermiogênese, quando as pontes intercelulares são quebradas e os espermatozóides são individualizados, o complexo de junções entre as células de Sertoli para a formação dos cistos sofre uma dinâmica remodelação que culmina na abertura do cisto e, consequentemente, a liberação dos espermatozóides no lúmen tubular (SCHULZ et al., 2010).

Em algumas espécies, a liberação das células germinativas ocorre na fase de espermátide e a espermiogênese é concluída no lúmen tubular. Este tipo de espermatogênese é chamado espermatogênese semicística (MATTEI, 1993).

Em relação à classificação das fases do ciclo reprodutivo, são as mesmas descritas acima para as fêmeas, sendo a fase imatura a caracterizada pela proliferação espermatogônias, tendo um crescimento independente de gonadotropinas. A partir do momento em que o peixe entra no ciclo reprodutivo 0 crescimento gonadal torna-se dependente de gonadotropina, e o peixe atinge a maturidade sexual entrando na fase de desenvolvimento, caracterizada pela espermatogênese ativa com a presença de espermatócitos primários e 
secundários, espermátides e espermatozoides somente dentro dos cistos. Posteriormente os peixes entram na fase aptos a se reproduzir, caracterizada pela presença e liberação de espermatozoides. O final do ciclo reprodutivo é indicado pela fase de regressão caracterizada por baixo estoque de espermatozoide no lúmen dos túbulos e uma diminuição do número de espermatocistos. E por fim, os animais entram na fase de regeneração onde os gametas sofrem intensa proliferação independente de gonadotropina em preparação para o próximo ciclo reprodutivo. Os peixes nesta fase são sexualmente maduros, mas reprodutivamente inativos (BROWN PETERSON, et al., 2011).

\section{OBJETIVOS}

O presente trabalho teve como objetivo caracterizar molecularmente 0 preproGnRH2 e o preproGnRH3, entender o perfil da expressão do $\mathrm{GnRH}$ e mudanças morfológicas gonadais ao longo de um estímulo reprodutivo, e avaliar as funções dos diferentes GnRHs. Para isso foram realizados os seguintes passos:

- $\quad$ Para a caracterização molecular do $\mathrm{GnRH}$ foi realizado a clonagem molecular do cDNA do preproGnRH2 e do preproGnRH3 de Astyanax altiparanae.

- Durante o estímulo reprodutivo por redução do nível da água foram analisadas as mudanças morfológicas e quantitativas das gônadas, a razão gonadossomática e o perfil de expressão gênica do $\mathrm{GnRH} 2$ e GnRH3 no encéfalo de machos e fêmeas de Astyanax altiparanae.

- E para avaliar a função dos GnRHs em Astyanax altiparanae foram analisadas as mudanças morfológicas e quantitativas nos ovários, a razão gonadossomática, o perfil da expressão gênica de $\beta \mathrm{LH}$ e $\beta F S H$ na hipófise e o

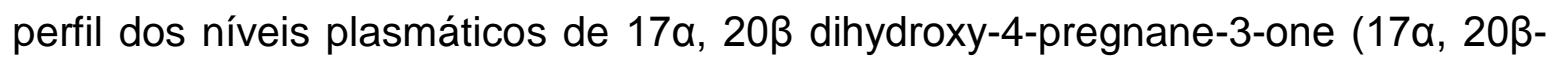
DHP), após a injeção dos peptídeos GnRH1, GnRH2 e GnRH3. 


\section{MATERIAL E MÉTODOS}

\subsection{Animais e desenhos experimentais}

Astyanax altiparanae, espécie da ordem Characiformes, de ambos os sexos foram utilizados para a experimentação (Figura 1A e 1B), alguns exemplares desses espécimes foram depositados no Museu de Zoologia da Universidade de São Paulo recebendo o número de tombo MZUSP 113746.

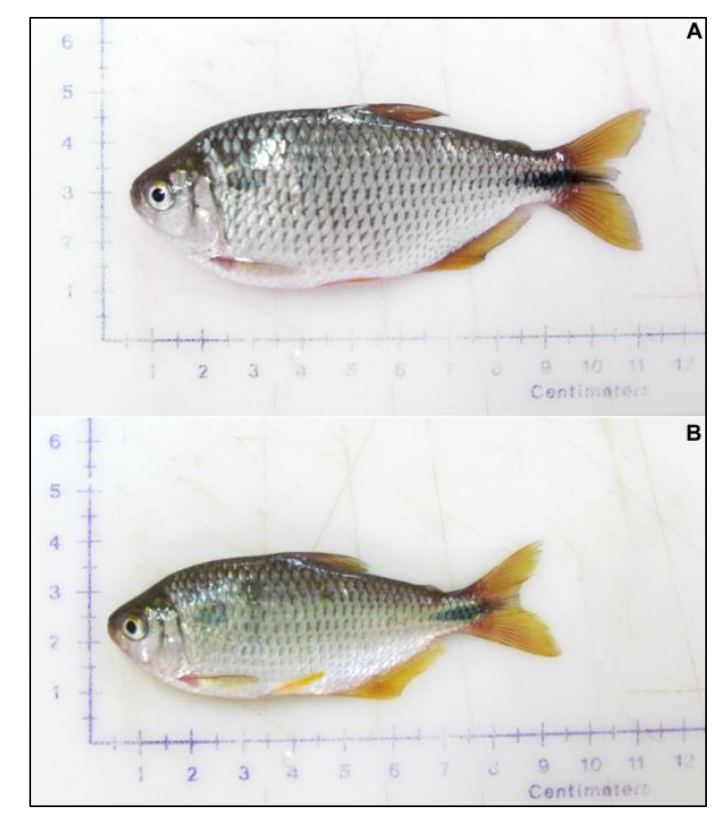

Figura 1. Astyanax altiparanae (lambaris do rabo amarelo) em (A) um exemplar representativo de fêmeas e em (B) um exemplar representativo de machos.

Antes de qualquer procedimento de dissecção, os animais foram eutanaziados por secção medular após terem sido anestesiados por solução alcoólica de benzocaína (100 mg/L), de acordo com o procedimento aprovado pela Comissão de Ética em Experimentação Animal do ICB, USP Proc. 2011/017. A classificação dos indivíduos em machos e fêmeas foi feita com base em seu dimorfismo sexual, onde os machos apresentam em sua morfologia externa espículas na nadadeira anal (GARUTTI; BRITSKI, 2000). Os indivíduos tiveram seu peso total $(\mathrm{Pt})$ e das gônadas $(\mathrm{Pg})$ mensurados em balança analítica com 
precisão de 0,001g. Segue abaixo a descrição dos desenhos experimentais realizados.

\subsubsection{Indução a reprodução por redução do nível da água}

O experimento e as coletas foram realizados na Estação de Piscicultura da Companhia Elétrica do Estado de São Paulo (CESP) em Paraíbuna, São Paulo

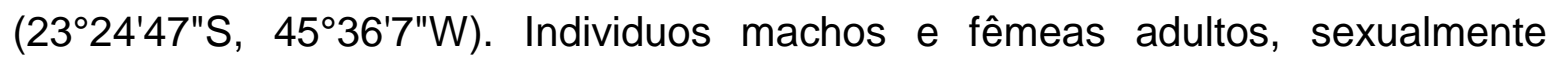
maduros mantidos juntos em tanques ao ar livre foram levados para o interior do laboratório da Estação de Piscicultura, onde machos e fêmeas ficaram separados em tanques com água corrente por 15 horas, após este período os machos foram colocados no mesmo tanque das fêmeas e em seguida o volume de água foi reduzido (Figura 2).

Foram feitas coletas de 4 em 4 horas, iniciadas 4 horas antes da redução do nível de água e mantidas até 28 horas após a mesma, sendo necessários 30 minutos em cada periodo amostral para a dissecção do animal e coleta dos tecidos de interesse. Em cada tempo de coleta, foram amostradas as gônadas e encéfalos de 16 fêmeas e 4 machos, sendo 12 encéfalos de fêmeas agrupados 3 a 3 , totalizando um número amostral de 4 , destinados à técnica de clonagem. Os outros 4 encéfalos de fêmeas, assim como os 4 encéfalos de machos foram coletados individualmente, portanto apresentando um número amostral de 4 para cada tempo de coleta, sendo estes animais destinados à análise do perfil de expressão gênica do $\mathrm{GnRH}$. As gônadas de cada animal foram retiradas para o acompanhamento do estádio de maturação gonadal. 


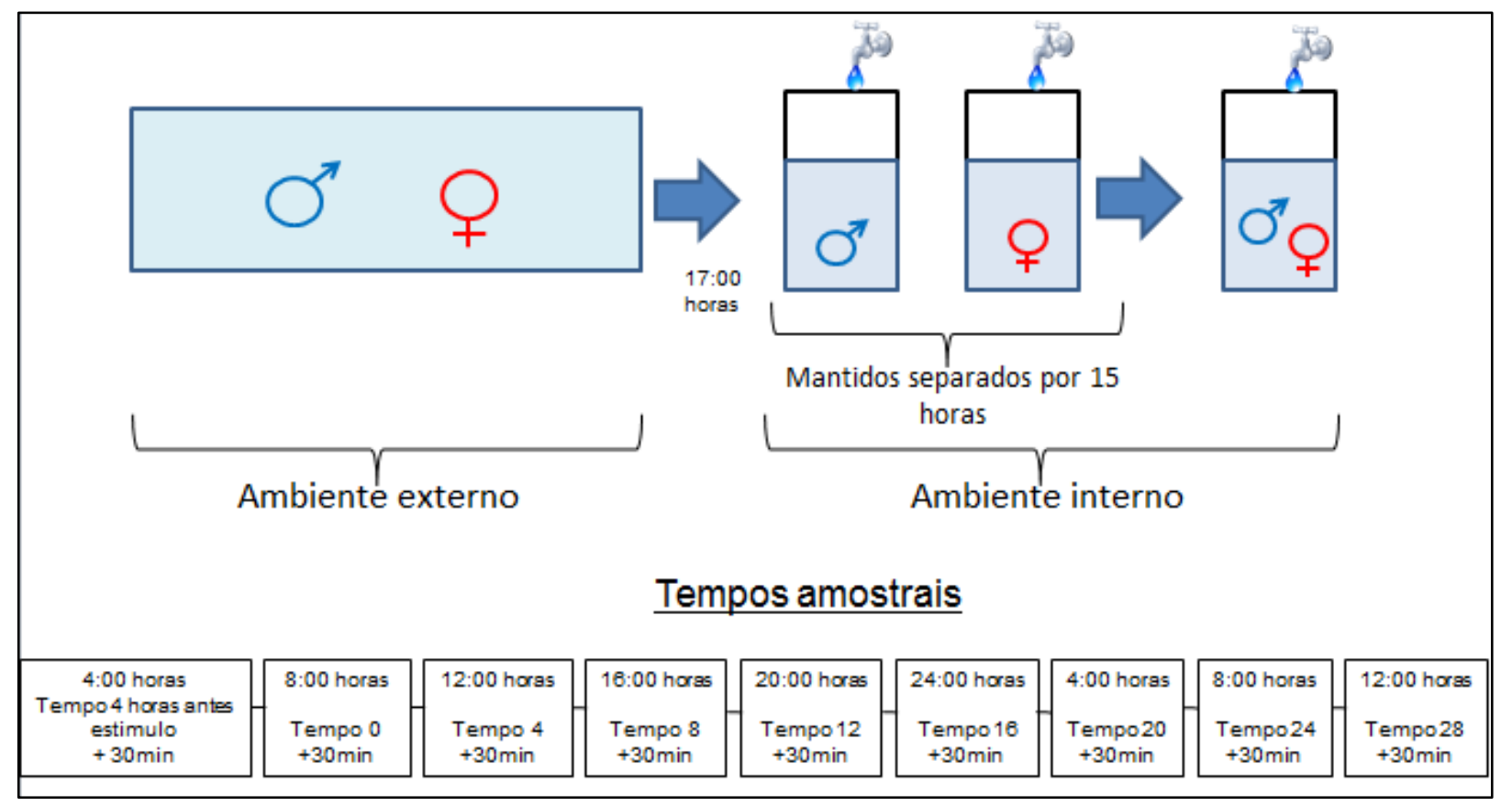

Figura 2. Esquema demonstrando o desenho experimental para a indução a reprodução pela redução do nível da água.

\subsubsection{Injeção dos GnRHs}

Os peptídeos injetados foram obtidos comercialmente pela empresa Bachem, GnRH1 (H-4284), GnRH2 (H-4288) e GnRH 3 (H-6845), sendo dissolvidos em solução fisiológica salina a $0,9 \%$. Cada fêmea e macho adultos em fase aptos à reprodução receberam uma injeção do $\mathrm{GnRH}(0,5 \mathrm{ug} / \mathrm{g}$ da massa corpórea) em volume correspondente a $10 \mu \mathrm{l} / \mathrm{g}$ de massa corpórea. No grupo controle, os animais foram injetados com volume igual de solução fisiológica salina (KIM et al., 2011).

As injeções de $\mathrm{GnRH}$, assim como de salina no grupo controle, foram realizadas às 16 horas, este horário foi determinado de acordo com o período de maior atividade dos neurônios de GnRH relatado ao longo do dia (KARIGO et al., 2012).

Os lambaris utilizados no experimento foram obtidos na estação de piscicultura da Companhia Energética do Estado de São Paulo (CESP) localizada

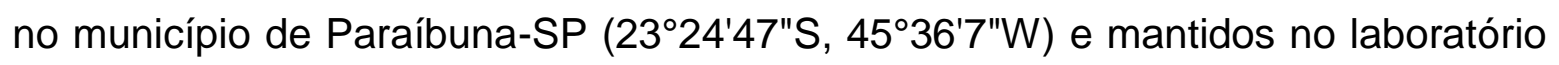
por um período de 40 dias para aclimatação. 
Foram sacrificados 5 animais por ponto amostral de cada grupo, sendo os pontos amostrais às 4 horas antes da injeção, às 2, 4, 10, 16 e 24 horas após injeção. Todos os animais tiveram seu sangue retirado para a avaliação do perfil de esteróides sexuais, as gônadas foram obtidas para a análise morfológica e as hipófises foram retiradas para análise da expressão gênica de $\beta \mathrm{LH}$ e $\beta F S H$.

\subsection{Fixação e processamento.}

As gônadas foram fixadas em Bouin e Karnovsky, e foram processadas de forma rotineira para inclusão em parafina.

Amostras de encéfalo e hipófises para a extração do RNA total foram conservadas a $-80^{\circ} \mathrm{C}$ até o procedimento de extração.

Amostras de sangue foram coletadas com seringas descartáveis de $1 \mathrm{ml}$, previamente heparinizadas (Liquemine-Roche ${ }^{\circledR}$ ). $O$ sangue coletado foi transferido para microtubos de $0,6 \mathrm{ml}$ também heparinizados, posteriormente as amostras foram centrifugadas por $5 \mathrm{~min}$ a $3000 \mathrm{rpm}$ e então armazenadas a $-80^{\circ} \mathrm{C}$ até 0 momento da determinação do esteróide gonadal.

\subsection{Análise quantitativa dos tipos celulares gonadais}

Foram obtidos cortes histológicos das gônadas com $5 \mu \mathrm{m}$ de espessura de forma contínua e com espaçamento de $200 \mu \mathrm{m}$ de distância entre cada um, e posteriormente corados com Hematoxilina/Eosina. Foram utilizados três cortes por indivíduo para caracterização morfológica e verificação quantitativa da distribuição dos tipos celulares germinativos presentes nas gônadas no decorrer dos tempos amostrais.

Foram utilizados $n=10$ fêmeas e $n=4$ machos para a análise quantitativa dos tipos celulares das gônadas dos animais submetidos à indução a reprodução pela redução do nível da água. Já para os animais que foram submetidos à injeção do $\mathrm{GnRH}$ descrito detalhadamente no item 4.1.2 foram analisados somente fêmeas sendo utilizado $n=4$ indivíduos por tempo amostral. 
Para fêmeas, foram contados os tipos celulares na área total do corte. Os tipos celulares germinativos foram discriminados em: oogônia, oócito inicial, oócito pré-vitelogênico, oócito vitelogênico, oócito maduro, complexos pós-ovulatórios e atresias (QUAGIO GRASSIOTTO et al. 2011). Para os machos, foi medida a área ocupada por cada tipo celular em 10 túbulos amostrados por corte. Os tipos celulares germinativos foram discriminados em: espermatogônia, espermatócito primário, espermatócito secundário, espermátide e espermatozoide (adaptado de SCHULZ et al. 2010).

Posteriormente, os dados quantitativos foram utilizados para a análise de proporção das classes celulares, por tempo amostral, tanto para machos e fêmeas submetidos à indução a reprodução por redução do nível da água, assim como para as fêmeas injetadas com os diferentes $\mathrm{GnRHs}$.

Por fim, no experimento de indução à reprodução pela redução do nível da água foi comparado o número total de complexos pós-ovulatórios de cada fêmea e a área total ocupada por espermatozoides de cada macho, por tempo amostral, com os testes Kruskal-Wallis e ANOVA, respectivamente, para a verificação se houve esvaziamento das gônadas. No experimento de injeção dos $\mathrm{GnRHs}$ foi comparado o número total de complexos pós-ovulatórios de cada grupo tratado com o grupo controle, por tempo amostral, com o teste de Two-Away ANOVA, para verificar se houve desova.

\subsection{Razão gonadossomática (RGS)}

Para verificar a variação gonadal ao longo dos tempos amostrais foi estimada a razão gonadossomática (RGS), que é a percentagem que as gônadas representam do peso total do indivíduo de acordo com a expressão estabelecida por VAZZOLER (1996): RGS $=(\mathrm{Pg} / \mathrm{Pt}){ }^{*} 100$. A comparação da RGS entre os tempos, para os animais submetidos ao estímulo à reprodução pela a redução do nível da água, foi analisada por meio do teste estatístico paramétrico ANOVA para machos e do teste estatístico não paramétrico de Kruskal-Wallis para fêmeas, após verificação de normalidade dos dados pelo teste de Lilliefors. Já para os 
animais injetados com GnRH a comparação da RGS entre o grupo tratado com $\mathrm{GnRH}$ e o grupo controle foi realizada pelo teste estatístico Two-Way ANOVA, seguido do pós teste de Bonferroni

\subsection{Clonagem do GnRH e obtenção de padrões}

\subsubsection{Extração de RNA total e tratamento com DNAse}

Os encéfalos e hipófises coletados foram lavados com PBS e seu RNA total extraído, utilizando o reagente Trizo|® (Ambion) na proporção $1 \mathrm{ml}$ para $100 \mathrm{mg}$ de tecido. O RNA total foi armazenado a $-80^{\circ} \mathrm{C}$ até sua utilização nos ensaios de RT-PCR e qRT-PCR. Para este procedimento, os encéfalos e hipófises foram homogeneizados e incubados com Trizol $\AA^{A}$ (Ambion) por 10 minutos em temperatura ambiente, precipitados com $100 \mu \mathrm{L}$ de clorofórmio e centrifugados por 15 minutos, $12.000 \mathrm{~g}$, a $4{ }^{\circ} \mathrm{C}$, para a separação do RNA total e proteínas. A fase contendo o RNA total foi removida e precipitada com $250 \mu \mathrm{L}$ de álcool isopropílico, $5 \mu \mathrm{L}$ de glicogênio $\AA$ (Invitrogen), sendo estes levados à temperatura de $-70^{\circ} \mathrm{C}$ overnight. As amostras foram novamente centrifugadas a $12.000 \mathrm{~g}$, por 10 minutos, a $4{ }^{\circ} \mathrm{C}$ e os pellets secos em temperatura ambiente por aproximadamente 15 minutos. As amostras foram solubilizadas em água contendo 0,1\% dietilpirocarbonato (DEPC) e a concentração e a pureza do RNA total foram calculadas no espectrofotômetro Nanodrop ${ }^{\circledR}$ (Thermo Scientific) na absobância $A_{260}$, por meio da relação $A_{260} / A_{280}$ (considera-se uma relação $260 / 280$ OD como satisfatória entre os valores de 1,8 e 2). Para verificação da integridade das amostras, foi realizada eletroforese em gel de agarose 1\% (Sigma Biochemical). Foram consideradas íntegras aquelas amostras que apresentaram as bandas ribossomais $18 S$ e $28 S$ intactas à visualização por transiluminação com luz ultravioleta após coloração com solução de brometo de etídio. As amostras foram conservadas a $-80 \stackrel{\circ}{\circ}$. Para a remoção de possíveis DNAs contaminantes, o RNA total extraído foi tratado com Turbo DNA-free ${ }^{\mathrm{TM}}$ (Ambion), de acordo com as instruções do fabricante. Resumidamente, $1 \mu \mathrm{L}$ da enzima Turbo DNase e 1,1 $\mu \mathrm{L}$ 
do tampão de reação foram adicionados a $10 \mu \mathrm{L}$ do RNA total e as reações foram incubadas a $37^{\circ} \mathrm{C}$ por 30 minutos. A reação foi interrompida pela adição de $2 \mu \mathrm{L}$ de tampão de inativação e posterior incubação à temperatura ambiente por 2 minutos, seguida de centrifugação $(10.000 \mathrm{~g}, 1,5$ minutos, $4 \stackrel{\circ}{\circ} \mathrm{C})$ para separação do sobrenadante. A concentração do RNA tratado foi aferida novamente por meio do espectrofotômetro Nanodrop ${ }^{\circledR}$ (Thermo Scientific).

\subsubsection{Obtenção do cDNA}

O cDNA destinado para a clonagem do $\mathrm{GnRH}$ foi sintetizado a partir de 3,0 $\mu \mathrm{g}$ de RNA total e o cDNA destinado para a análise da expressão gênica foi sintetizado a partir de $1 \mu \mathrm{g}$ de RNA total. Foi adicionado ao RNA total $1 \mu \mathrm{L}$ de Oligo dT (Invitrogen) $(0,05 \mu \mathrm{g} / \mu \mathrm{L}), 1 \mu \mathrm{L}$ de SuperScript ${ }^{\mathrm{TM}}$ III Reverse Transcriptase (Invitrogen) e água DEPC (q.s.p. $20 \mu \mathrm{L}$ ) (Invitrogen) por 10 minutos a $70^{\circ} \mathrm{C}, 50$ minutos a $42^{\circ} \mathrm{C}$, e 15 minutos a $70^{\circ} \mathrm{C}$ no termociclador Mastercycler ${ }^{\circledR}$ ep gradiente (Eppendorf). O cDNA foi fracionado em gel de agarose a 1\% (Sigma Biochemical), corado com brometo de etídio e visualizado em transiluminador. As amostras de cDNA foram armazenadas a $-20^{\circ} \mathrm{C}$.

\subsubsection{Amplificação do cDNA.}

Devido à ausência de informação sobre a sequência nucleotídica e proteica dos GnRHs desta espécie, utilizamos como estratégia inicial a amplificação de fragmentos utilizando primers degenerados e/ou primers flanqueadores de regiões conservadas de diferentes espécies (Tabela 1). Assim, para cada conjunto de primers, as condições específicas das reações de amplificação foram padronizadas (p.e., temperatura de anelamento e concentração de $\mathrm{MgCl}_{2}$ do tampão), a partir das condições padrão de RT-PCR: 10X PCR Buffer; 50mM de $\mathrm{MgCl}_{2} ; 0,5$ mM de dNTP; $1,0 \mu \mathrm{l}$ de cDNA; $1 \mathrm{U}$ de Platinum® Taq DNA Polymerase; pares de primers específicos $(10 \mu \mathrm{M}$ de primer forward e $10 \mu \mathrm{M}$ de primer reverse). Estas reações foram submetidas ao seguinte programa do termociclador 
Mastercycler® ep gradiente (Eppendorf): 1) etapa inicial de ativação da enzima a $94{ }^{\circ} \mathrm{C}$ por 5 minutos, 2) 40 ciclos que incluem a desnaturação a $94{ }^{\circ} \mathrm{C}$ por 1 minuto, o anelamento dos primers a uma temperatura especifica de cada primer, geralmente de $56^{\circ} \mathrm{C}$ a $60^{\circ} \mathrm{C}$ por 1 minuto e $72^{\circ} \mathrm{C}$ para extensão e 3) 1 ciclo de 72 ${ }^{\circ} \mathrm{C}$ para extensão final. Para verificar a amplificação dos fragmentos de interesse nos PCRs realizados, as amostras foram submetidas à eletroforese em gel de agarose 1-2\% (Sigma Biochemical), corado com brometo de etídeo em tampão $1 \mathrm{X}$ TAE (Tris-Acetato-EDTA). A amostra foi aplicada com 1X tampão de amostra [10 $\mathrm{mM}$ Tris- $\mathrm{HCl}(\mathrm{pH} 7,6), 0,03 \%$ azul de bromofenol, 0,03\% xileno cianol, 60\% glicerol e $60 \mathrm{mM}$ de EDTA]. Após o fracionamento, o gel foi fotodocumentado com o auxílio de luz ultravioleta. Os fragmentos de interesse no peso molecular esperado foram recortados do gel com o auxílio de uma lâmina em luz UV. As bandas extraídas foram purificadas utilizando-se o kit QIAquick Gel Extraction Kit (Qiagen), de acordo com as recomendações do fabricante.

Os fragmentos com o peso molecular de interesse obtidos da amplificação do cDNA foram purificados e então subclonados utilizando o kit pGEM_T Easy® (Promega) de acordo com as instruções do fabricante. Resumidamente, foi realizada a ligação do produto de interesse com o vetor acima citado, por meio da enzima T4 ligase juntamente com $3 \mu \mathrm{l}$ do produto purificado, $5 \mu \mathrm{l}$ do tampão de ligação e $0,5 \mu \mathrm{l}$ do vetor pGEM-T Easy ${ }^{\circledR}$ (Promega), a reação foi gentilmente misturada e incubada a temperatura ambiente por 1 hora (Figura 3 ).

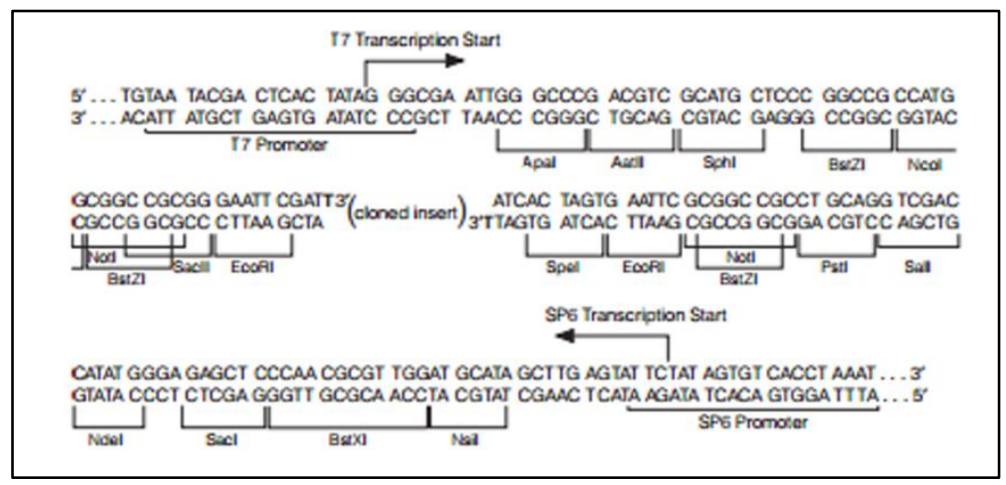

Figura 3. Mapa do vetor pGEM-T easy mostrando o sítio de inserção do fragmento, com os diversos posicionamentos dos sítios de restrição para várias enzimas e a localização dos dois promotores para início da transcrição. 
Posteriormente foi realizada a transformação de bactéria $E$. coli competentes com o fragmento inserido no vetor. Para isso foi adicionado $2 \mu \mathrm{L} d a$ ligação a $50 \mu \mathrm{L}$ de bactérias $E$. coli competentes. A reação foi incubada 30 minutos em gelo, seguidos de 2 minutos a $42{ }^{\circ} \mathrm{C}$ e de 1 minuto novamente no gelo. Esse procedimento de transformação é conhecido como heat-shock. As bactérias transformadas foram adicionadas a $800 \mu \mathrm{L}$ de meio LB-Broth ${ }^{\circledR}$ (Invitrogen) e incubadas a $37^{\circ} \mathrm{C}$ por 1 hora, com agitação plana de $225 \mathrm{rpm}$.

As bactérias foram então semeadas em placas de cultura com meio LB (Luria Bertani) Agar (Gibco) adicionado de $1 \mathrm{mg} / \mathrm{mL}$ de ampicilina (Sigma Biochemical), $100 \mu \mathrm{L}$ de IPTG (isopropil-B-D-tiogalactosídeo) e $20 \mu \mathrm{L}$ de X-gal (5bromo-4-cloro-3-indoil-B-D-galactosídeo), ambos da Invitrogen. As placas foram incubadas em estufa a $37^{\circ} \mathrm{C}$ por 12 horas.

Devido à aplicação de IPTG e X-gal, pôde-se realizar a seleção das colônias bacterianas que possuíam o inserto de interesse. Colônias azuis não continham inserto, possuindo vetores intactos que puderam expressar Bgalactosidase ativa capaz de reagir com X-gal e resultar na coloração azul. Colônias brancas por sua vez apresentavam o inserto que interrompeu a sequência codificadora da ß-galactosidase (SAMBROOK; RUSSEL, 2001).

Após incubação, 2 colônias brancas de cada fragmento foram adicionadas individualmente a tubos contendo $5 \mathrm{~mL}$ de meio LB (Luria Bertani, Gibco) acrescidos de $5 \mu \mathrm{L}$ de ampicilina ( $1 \mathrm{mg} / \mathrm{mL}$, Sigma Biochemical). As culturas líquidas foram incubadas a $37^{\circ} \mathrm{C}$ por 12 horas, com agitação plana de $225 \mathrm{rpm}$.

As amostras foram centrifugadas a $5.000 \mathrm{rpm}$ por 10 minutos para formação do precipitado de bactérias, o sobrenadante foi descartado e a obtenção de mini-prep foi feita utilizando o kit QIAprep® Miniprep (Qiagen), de acordo com as especificações do fabricante. As preparações tiveram suas concentrações aferidas pelo aparelho NanoDrop ${ }^{\mathrm{TM}} 1000$ (Thermo Scientific).

O material genético das bactérias recombinantes obtido pela preparação de mini-prep foi submetido à análise de restrição com a enzima EcoRI (Fermentas Life Sciences) e posterior eletroforese em gel de agarose 1\% (Sigma Biochemical) para confirmação da presença do fragmento de interesse. As preparações que se 
evidenciaram positivas para presença do fragmento foram enviadas para sequenciamento utilizando os serviços do Centro de Estudos do Genoma Humano na Universidade de São Paulo, em concentração de $20 \mathrm{ng} / \mu \mathrm{L}$ do plasmídeo, em 5 $\mu \mathrm{L}$ da solução de eluição acrescidos de $2.5 \mu \mathrm{L}$ de primer sense e em uma segunda amostra com primer antisense. As amostras foram sequenciadas utilizando o sistema de análise de DNA de 96 capilares. As reações de sequenciamento foram realizadas de acordo com o protocolo para o MegaBACE 1000, utilizando o DYEnamic ET Dye Terminator Kit (com Thermo Sequenase ${ }^{\text {TM }}$ II DNA Polimerase) código US81090. Estas reações de sequenciamento possuem fidelidade de análise de 98,5\%.

As sequências foram analisadas primeiramente pelo software BioEdit (Ibis Biosciences) e posteriormente utilizou-se a interface BLAST para a verificação de similaridade do produto com a sequência gênica de $\mathrm{GnRH}$. Uma vez confirmada à amplificação de um fragmento do gene de interesse, a sequência parcial obtida foi utilizada para desenho de novos primers para extensão 5' e 3' do gene (RACE) (Tabela 1).

Em relação à clonagem realizada para a obtenção dos padrões utilizados na reação Reação em Cadeia da Polimerase (PCR) em Tempo Real, os fragmentos clonados foram considerados adequados para uso como padrão nas reações quando apresentaram similaridade às sequências descritas para aqueles genes na referida base de dados (Ver Anexo I - Sequências dos padrões para PCR em tempo real).

A obtenção de $10^{9}$ cópias dos fragmentos clonados foi feita através de cálculos matemáticos utilizando a concentração e tamanho dos plasmídeos, o tamanho dos fragmentos clonados e o número de Avogadro. Diluições seriadas $\left(10^{7}\right.$ a $10^{2}$ cópias) foram feitas em água Ultra Pure® (Invitrogen) imediatamente antes de cada reação de PCR em tempo real. Cada diluição foi pipetada em duplicata e passou pelos mesmos procedimentos descritos para as amostras. Tanto amostras quanto diluições para curva padrão foram sempre amplificadas no mesmo bloco de reações. 


\subsubsection{RACE 3'e 5' (Rapid amplification of cDNA ends).}

As amplificações das terminações de cDNA foram realizadas com RNA total obtido da extração feita com Trizol. Os procedimentos foram feitos utilizando o kit First Choice ${ }^{\circledR}$ RLM-RACE (Ambion) de acordo com as especificações do fabricante. Resumidamente, para o ensaio de 5'RACE, o RNA total previamente extraído foi tratado com fosfatase alcalina (CIP) e em seguida a amostra foi tratada com pirofosfatase ácida (TAP). Um oligonucleotídeo de 45 bases (adaptador de RNA fornecido pelo fabricante) foi ligado às moléculas de RNA e reações de transcrição reversa e de PCR amplificam a região 5' do transcrito de interesse, através do uso de primers específicos para estes transcritos e dos primers fornecidos pelo fabricante.

Para o 3'RACE, o procedimento consiste na síntese de cDNA utilizando RNA previamente extraído e o adaptador 3' de ancoragem fornecido pelo fabricante. Este cDNA foi então submetido à reação de PCR usando primer 3'RACE complementar ao adaptador de ancoragem (fornecido igualmente pelo fabricante) e primer específico para o transcrito de interesse.

As reações de RT-PCR para amplificação dos fragmentos 3' e 5' foram realizadas utilizando a enzima Herculase II Fusion DNA Polimerase (Agilent Technologies).

Uma vez amplificados, os fragmentos foram purificados (como previamente descrito), subclonados e sequenciados. A clonagem foi realizada utilizando o kit Zero Blunt ${ }^{\circledR}$ PCR Cloning (Invitrogen) (Figura 4) de acordo com as instruções do fabricante. As culturas líquidas foram processadas para obtenção de mini-prep utilizando o kit QIAprep® Miniprep (Qiagen), também de acordo com as instruções do fabricante. As sequências obtidas foram alinhadas para a obtenção do mRNA completo do $\mathrm{GnRH}$. 


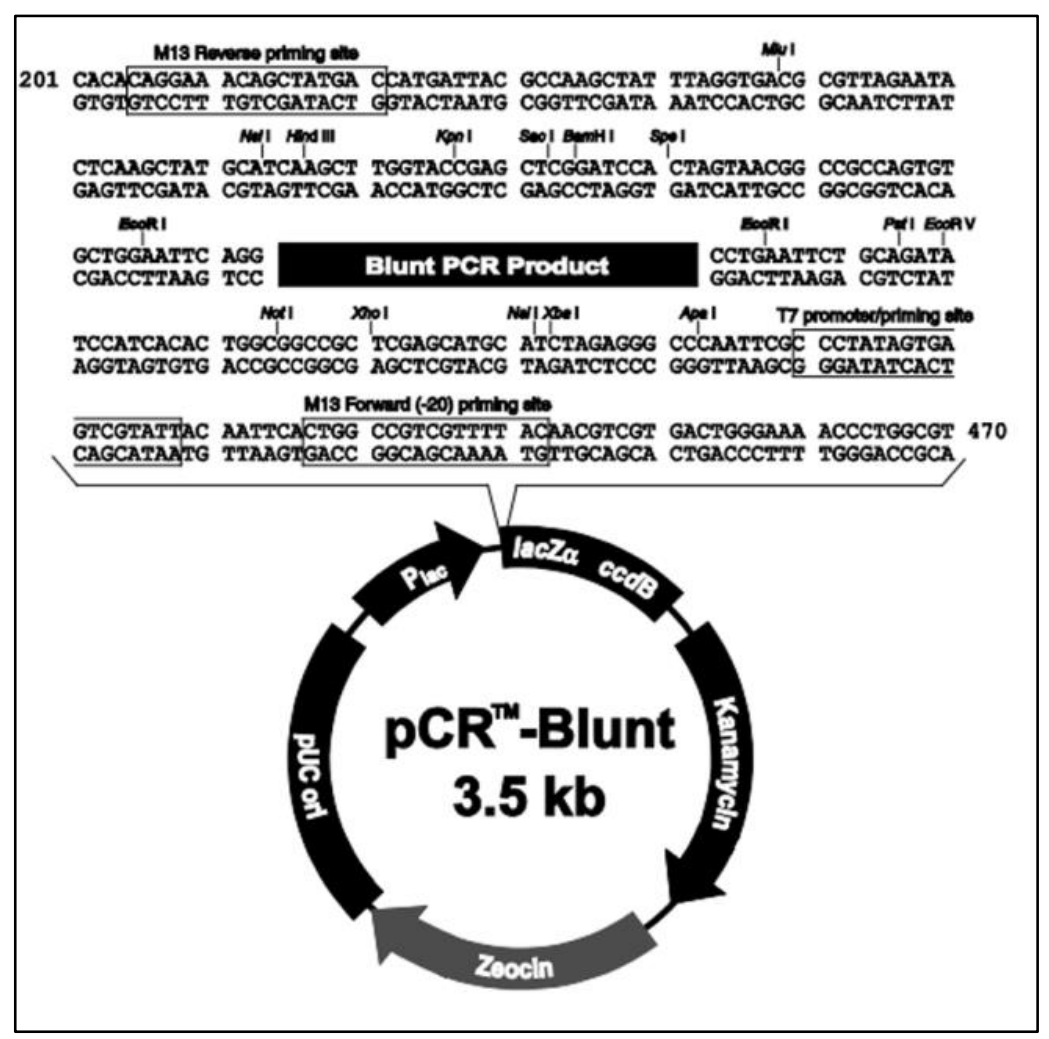

Figura 4. Mapa do vetor Zero Blunt® mostrando o sítio de inserção do fragmento, com os diversos posicionamentos dos sítios de restrição para várias enzimas.

\subsection{Análise das sequências}

A dedução da sequência de aminoácidos das sequências obtidas foi realizada por meio do software BioEdit (Ibis Biosciences).

O alinhamento e a construção das árvores foram desenvolvidos por meio do software Seaview (GOUY et al., 2010), utilizando o algoritmo muscle e de PhyML (método de máxima verossimilhança), respectivamente. $O$ teste de boostrap foi calculado para 1000 replicatas, sendo levado em consideração somente os valores de boostrap gerados maiores ou igual a $70 \%$.

As sequências dos preproGnRH2 utilizadas para a construção da árvore filogenética, possuem os seguintes números de acesso no banco de dados disponível no NCBI: gi|18253178 (Verasper moseri), gi|256418972 (Danio rerio), gi|89274017 (Gallus gallus), gi|4185503 (Macaca mulata), gi|10432440 (Homo sapiens), gi|37718697 (Eublepharis macularius), gi|15718453 (Rana catesbeiana), Gl:398025502 (Engraulis japonicus), gi|26006872 (Cyprinus carpio), gi|386873959 
(Gobiocypris rarus), gi|597786266 (Astyanax mexicanus), gi|38426653 (Salmo salar), gi|34391955 (Coregonus clupeaformis), gi|185132720 (Oncorhynchus mykiss), gi|57471985 (Monopterus albus), gi|658850348 (Poecilia reticulata), gi|219964513 (Epinephelus coioides), gi|1708014 (Sparus aurata), gi|159906354 (Thunnus thynnus), gi|459430 (Clarias gariepinus), gi|21955960 (Oryzias latipes), gi|53827983 (Odontesthes bonariensis), gi|34872167 (Mugil cephalus), gi|7453587 (Dicentrarchus labrax) e gi|5596356 (Anguilla japonica) utilizado este como grupo externo.

As sequências dos preproGnRH3 utilizadas para a construção da árvore filogenética, possuem os seguintes números de acesso no banco de dados disponível no NCBI: gi|597791854 (Astyanax mexicanus), gi|256418970 (Danio rerio), gi|21780211 (Cyprinus carpio), gi|1293922 (Carassius auratus), gi|197941113 (Ctenopharyngodon idella), gi|386873961 (Gobiocypris rarus), gi|3122162 (Rutilus rutilus), gi|157366854 (Pimephales promelas), gi|398025504 (Engraulis japonicus), gi|34391957 (Coregonus clupeaformis), gi|59799541 (Oncorhynchus nerka), gil1169991 (Salmo trutta), gi|59799539 (Salmo salar), gi|50400582 (Verasper moseri), gi|291292269 (Gadus morhua), gi|157278084 (Oryzias latipes), gi|53827985 (Odontesthes bonariensis), gi|564731618 (Centropristis striata), gi|406717428 (Sebastes schlegelii), gi|426204170 (Gasterosteus aculeatus), gi|28201252 (Oreochromis niloticus), gi|3342829 (Haplochromis burtoni), gi|14916577 (Dicentrarchus labrax), gi|57471987 (Monopterus albus), gi|1708012 (Sparus aurata), gi|17061831 (Scleropages jardinii) utilizado como grupo externo.

\subsection{Análise quantitativa da expressão gênica por reação em cadeia da polimerase (PCR) em tempo real}

A análise quantitativa da expressão gênica foi realizada através da técnica de PCR em tempo real utilizando o aparelho StepOne Plus ${ }^{\circledR}$ (Applied Biosystem). Os ensaios foram realizados em duplicata utilizando $1 \mu \mathrm{L}$ de cDNA (10 $\mathrm{ng} / \mu \mathrm{L}$ ) previamente sintetizado, adicionado à mistura da reação contendo $6,25 \mu \mathrm{L}$ de 
SYBR Green mix (Applied Biosystem), 4,25 $\mu \mathrm{L}$ de água UltraPure ${ }^{\circledR}$ (Invitrogen) e $400 \mathrm{nM}$ dos primers específicos para cada gene (Tabela 1).

Os primers utilizados foram desenhados com auxilio do software Gene Runner 3.01, respeitando as seguintes especificações: amplificar fragmentos cujo tamanho varie entre $80-160 \mathrm{pb}$, apresentar quantidades de citosina e guanina entre 45 e $65 \%$, não apresentar capacidade de formar dímeros ou estruturas secundárias e apresentar temperatura de anelamento entre $58^{\circ} \mathrm{C}$ e $60^{\circ} \mathrm{C}$.

A eficiência dos pares de primers foi testada e determinada por reação de PCR em tempo real utilizando diluições $\left(10^{7}\right.$ a $10^{2}$ cópias) dos respectivos fragmentos clonados, nas mesmas condições e com o mesmo aparelho usado para todas as reações subsequentes. A determinação da eficiência se deu pela análise de regressão linear feita utilizando o software StepOne Plus ${ }^{\circledR}$ (Applied Biosystem). Todos os pares de primers usados foram considerados adequados quando apresentaram eficiência entre 1,8 e 2,0.

Os parâmetros de amplificação foram os seguintes: 1) etapa inicial de ativação da enzima a $95{ }^{\circ} \mathrm{C}$ por 10 minutos, 2) 40 ciclos que incluem a desnaturação a $95^{\circ} \mathrm{C}$ por 15 segundos e o anelamento dos primers a $60^{\circ} \mathrm{C}$ por 30 segundos, e 3) 1 ciclo para análise do melting que consiste em $95^{\circ} \mathrm{C}$ por 30 segundos; $60^{\circ} \mathrm{C}$ por 1 minuto e posterior aumento gradativo da temperatura para $95{ }^{\circ} \mathrm{C}$ para obtenção das curvas de melting. $\mathrm{O}$ controle da reação por exclusão do cDNA foi realizado para averiguar possíveis contaminações com DNA genômico.

O limiar para desconsideração do ruído na fluorescência de cada amostra foi determinado automaticamente pelo software de análise StepOne Plus ${ }^{\circledR}$ (Applied Biosystem), que também determinou as curvas de melting além de quantificar o número de cópias de cada gene utilizando o método de derivação secundária.

Esse método consiste em determinar o número de cópias de cada gene pela comparação entre $\mathrm{o}$ valor de amplificação (crossing point e curva de amplificação) de cada amostra, com a curva de padrões composta de diluições de plasmídeos recombinantes que contêm cópias clonadas dos genes de interesse e 
constitutivos ( $10^{7}$ a $10^{2}$ cópias). Os procedimentos de clonagem e obtenção dos padrões estão descritos no item 4.5.

Após a determinação do número de cópias de cada gene, o valor obtido para os genes de interesse foi normalizado pelo número de cópias do gene constitutivo EF-1 $\alpha$ (Elongation fator-1 $\alpha$ ).

Para análise da expressão gênica do GnRH2 e GnRH3 em machos e fêmeas durante o estímulo reprodutivo por redução do nível da água foi utilizado o teste estatístico One Way ANOVA seguido do pós teste de Tukey.

Para a análise da expressão gênica do $\beta \mathrm{LH}$ e do $\beta F S H$ em fêmeas entre os grupos tratados (injetados com $\mathrm{GnRH}$ ) e controle, e nos diferentes tempos, foi utilizada análise de variância com dois fatores para medidas repetidas (Two-way ANOVA) e o pós-teste de Bonferroni para determinar onde ocorreram as diferenças. 
Tabela 1. Sequência dos primers e a finalidade de cada técnica a qual eles foram empregados.

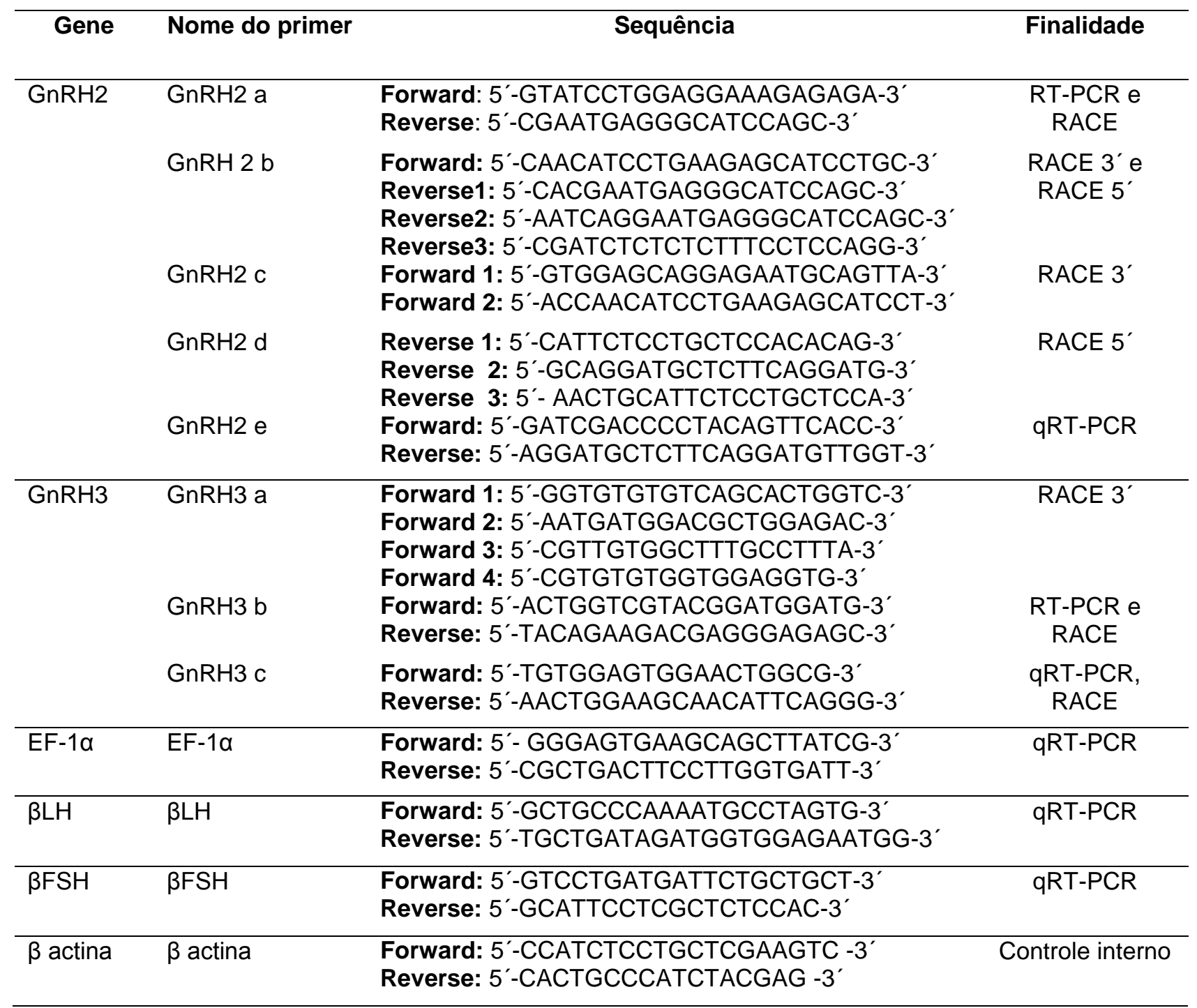

\subsection{Determinação do $17 \alpha, 20 \beta$, dihidroxi-4pregnen-3-one.}

O esteróide gonadal $17 \alpha 20 \beta$ dihidroxi-4pregnen-3-one $(17,20 \mathrm{DHP})$ foi quantificado no plasma dos animais por elisaimunoensaio (ELISA), utilizando-se placas de ELISA com anticorpos específicos. O principio do método destes ensaios hormonais envolve a ligação competitiva do anticorpo específico presente na placa de ELISA com o hormônio presente no plasma do animal e/ou o hormônio marcado adicionado à reação. Desta forma, quanto maior a quantidade de hormônio presente no plasma do animal, menor vai ser a reação entre o 
anticorpo e o hormônio marcado, e consequentemente menos intenso será a formação do complexo anticorpo-hormônio marcado, o que resulta em leituras com menores valores de absorbância no espectrofotômetro.

Para a realização da reação de ELISA primeiramente as amostras foram descongeladas até atingir a temperatura ambiente e então diluídas 1:10. Posteriormente, na placa foi pipetado em cada poço $50 \mu \mathrm{l}$ de cada um dos 8 padrões em duplicata, formando assim a curva padrão com as concentrações conhecidas (250, 125, 62.5, 31.3, 15.6, 7.8, 3.9 e $1.95 \mathrm{ng} / \mathrm{ml}$ ) (Maturation-inducing Steroid, salmonid, EIA Standard, Cayman chemical®). Nos poços subjacentes foram pipetados, também em duplicata, $50 \mu \mathrm{l}$ das amostras a serem analisadas. Para completar a reação, foi adicionado $50 \mu \mathrm{l}$ do hormônio MIS conjugado com acetilcolinesterase (Maturation-inducing Steroid, salmonid, AChE Tracer, Cayman chemical ${ }^{\circledR}$ ) e $50 \mu \mathrm{l}$ do antisoro (Maturation-inducing Steroid, salmonid, Antiserum Cayman chemical $($ ) em cada poço das amostras e dos padrões, por fim a placa ficou em agitação a $4{ }^{\circ} \mathrm{C}$ por 18 horas a $170 \mathrm{rpm}$. Após este período, os poços foram lavados com tampão de lavagem, e então adicionados $200 \mu \mathrm{l}$ da solução de Ellman's, a qual apresenta o substrato para a acetilcolinesterase, e incubados a temperatura ambiente por 90 min a 170 rpm. O produto desta reação enzimática apresenta a coloração amarela.

Posteriormente à incubação, as amostras e os padrões foram lidos em leitora de microplaca de ELISA (Tecan-Sunrise) a um comprimento de onda de $450 \mathrm{~nm}$.

\subsubsection{Validação dos ensaios de ELISA}

Os ensaios hormonais disponíveis no mercado na maioria das vezes não são desenvolvidos para espécies de peixes neotropicais, como podemos observar no item 4.8 que os reagentes utilizados para os ensaios foram desenvolvidos para espécies de Salmonídeos. Este fato não impede que tais reagentes sejam usados, no entanto é necessário realizar a validação dos ensaios para a espécie em estudo. 
Com isso, para validação dos ensaios desenvolvidos no presente trabalho foi realizado o coeficiente de variação intraensaio, no qual foram verificados os resultados das dosagens de uma mesma amostra em uma mesma placa, ou seja, as duplicatas. E também foi realizado o coeficiente de variação interensaio, no qual uma mesma amostra é dosada novamente depois de pelo menos 24 horas, em outro ensaio.

Nessa validação, os valores obtidos foram comparados, e foi calculada a porcentagem de variação entre os mesmo.

\section{RESULTADOS}

\subsection{Caracterização molecular do preproGnRH2}

A sequência completa do cDNA de preproGnRH2 de Astyanax altiparanae foi obtida pela sobreposição dos fragmentos amplificados a partir do 5' e 3' RACEPCR. Tal sequência apresentou 612 pb, sendo 158 pb da região não codificante $5^{\prime} \mathrm{UTR}, 258 \mathrm{pb}$ da predita fase de leitura aberta (ORF) que codifica uma proteína de 86 aminoácidos e 196 pb da região não codificante 3'UTR. A sequência de nucleotídeos e a predita sequência de aminoácidos estão demostradas na figura 5 .

A sequência de aminoácidos do preproGnRH2 de A. Altiparanae, deduzida por meio do software BioEdit, mostrou-se característica apresentando o peptídeo sinal (1-24 aa), o GnRH2 específico (25-34 aa), o lado de clivagem proteolítico (36-38 aa) e a proteína acoplada ao GnRH2 (39-86 aa) (Figura 5). 


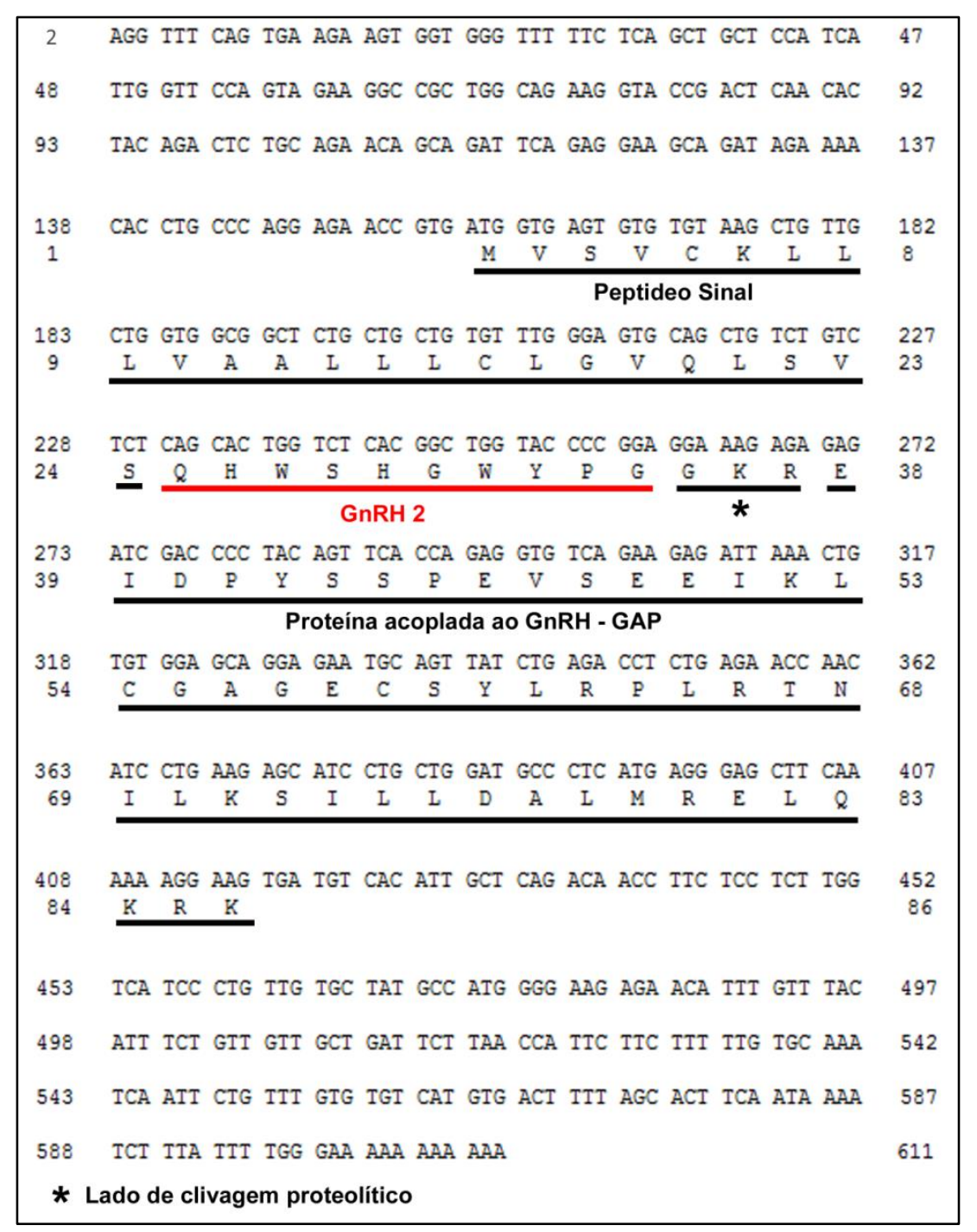

Figura 5. A sequência completa do cDNA e da predita sequência de aminoácidos do preproGnRH2 de Astyanax altiparanae. A sequência total de nucleotídeos apresenta $612 \mathrm{pb}$, sendo $158 \mathrm{pb}$ da região não codificante $5^{\prime}$ UTR, $258 \mathrm{pb}$ da predita fase de leitura aberta (ORF) que codifica uma proteína de 86 aminoácidos e 196 pb da região não codificante 3'UTR.

Usando o algoritmo BLAST (Blastx; National Center for Biotechnology Information) foi observado que a sequência de aminoácidos do preproGnRH2 de Astyanax altiparanae apresenta similaridade com a sequência de aminoácidos do preproGnRH2 de outros teleósteos como: 99\% com preproGnRH2 Astyanax mexicanus (Characiformes), $89 \%$ com preproGnRH2 de Clarias gariepinus (Siluriformes), 77\% com preproGnRH2 de Cyprinus carpio (Cypriniformes), 72\% com preproGnRH2 de Sparus aurata (Perciforme), 75\% com preproGnRH2 de 
Verasper moseri (Pleuronectiformes), 71\% com preproGnRH2 de Mugil cephalus (Mugiliformes), 72\% com preproGnRH2 de Salmo salar (Salmoniformes), 73\% com preproGnRH2 Odontesthes bonariensis (Atheriniformes), 69\% com preproGnRH2 de Oryzias latipes (Beloniformes), 72\% com preproGnRH2 de Monopterus albus (Synbranchiformes), 65\% com preproGnRH2 de Anguilla japonica (Anguilliformes) e 57\% com preproGnRH2 de Scleropages jardinii (Osteoglossiformes) (Figura 6).

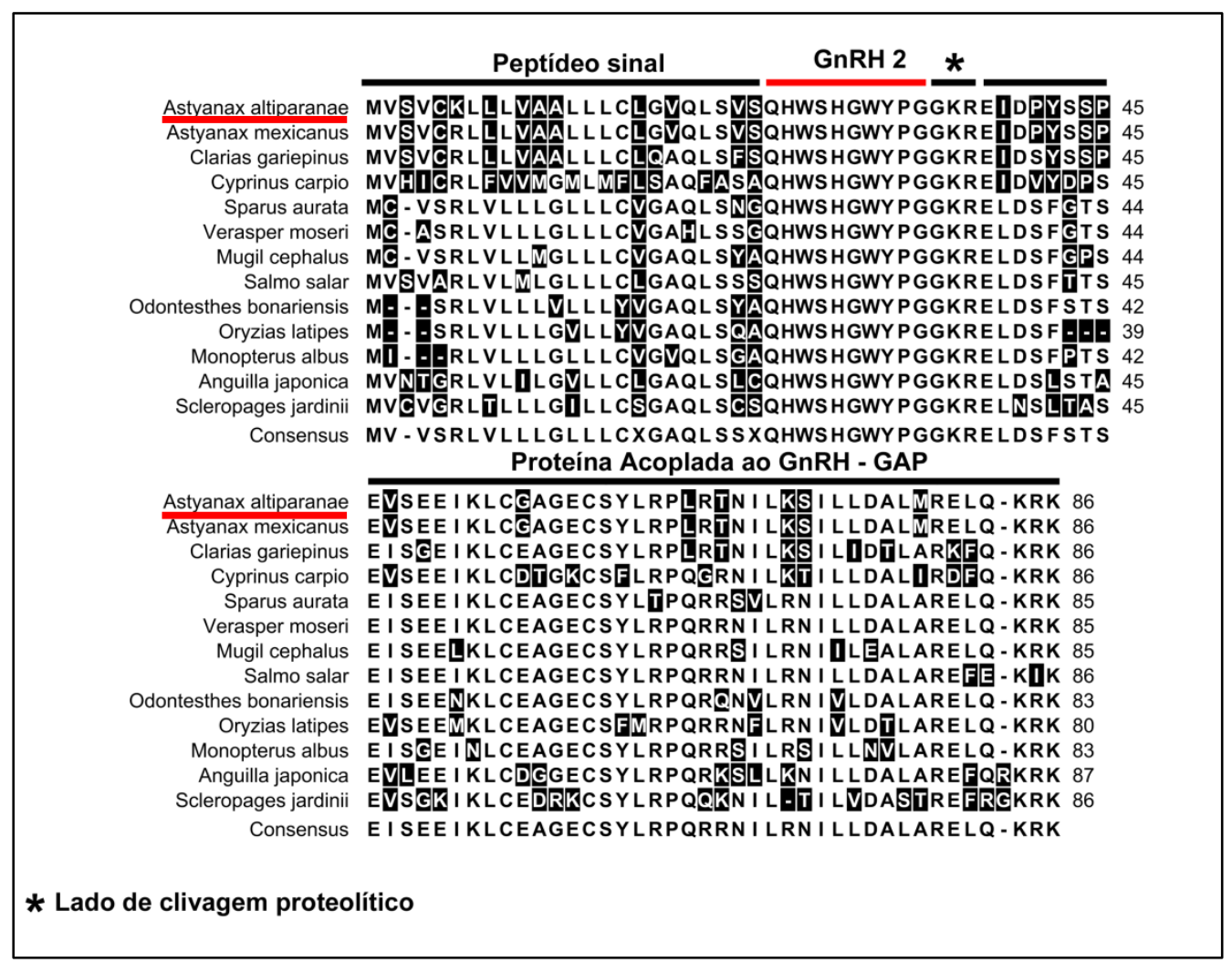

Figura 6. Alinhamento das preditas sequências de aminoácidos a partir do cDNA do preproGnRH2 de Astyanax altiparanae e outras espécies de teleósteos. As sequências foram obtidas no banco de dados do GeneBank. Os resíduos de aminoácidos diferentes estão envoltos por uma caixa da cor preta.

\subsection{Caracterização molecular do preproGnRH3}

A sequência completa do cDNA de preproGnRH3 de Astyanax altiparanae foi obtida pela sobreposição dos fragmentos amplificados a partir do 5' e 3' RACEPCR. Tal sequência apresentou $407 \mathrm{pb}$, sendo 13 pb da região não codificante 
5'UTR, 294pb da predita fase de leitura aberta (ORF) que codifica uma proteína de 98 aminoácidos e $99 \mathrm{pb}$ da região não codificante $3^{\prime}$ UTR. A sequência de nucleotídeos e a predita sequência de aminoácidos estão demostradas na figura 7.

A sequência de aminoácidos do preproGnRH3 de A. Altiparanae, deduzida por meio do software BioEdit, mostrou-se característica apresentando o peptídeo sinal (1-27 aa), o GnRH3 específico (28-37 aa), o lado de clivagem proteolítico (36-37 aa) e a proteína acoplada ao GnRH3 (41-98 aa) (Figura 7).

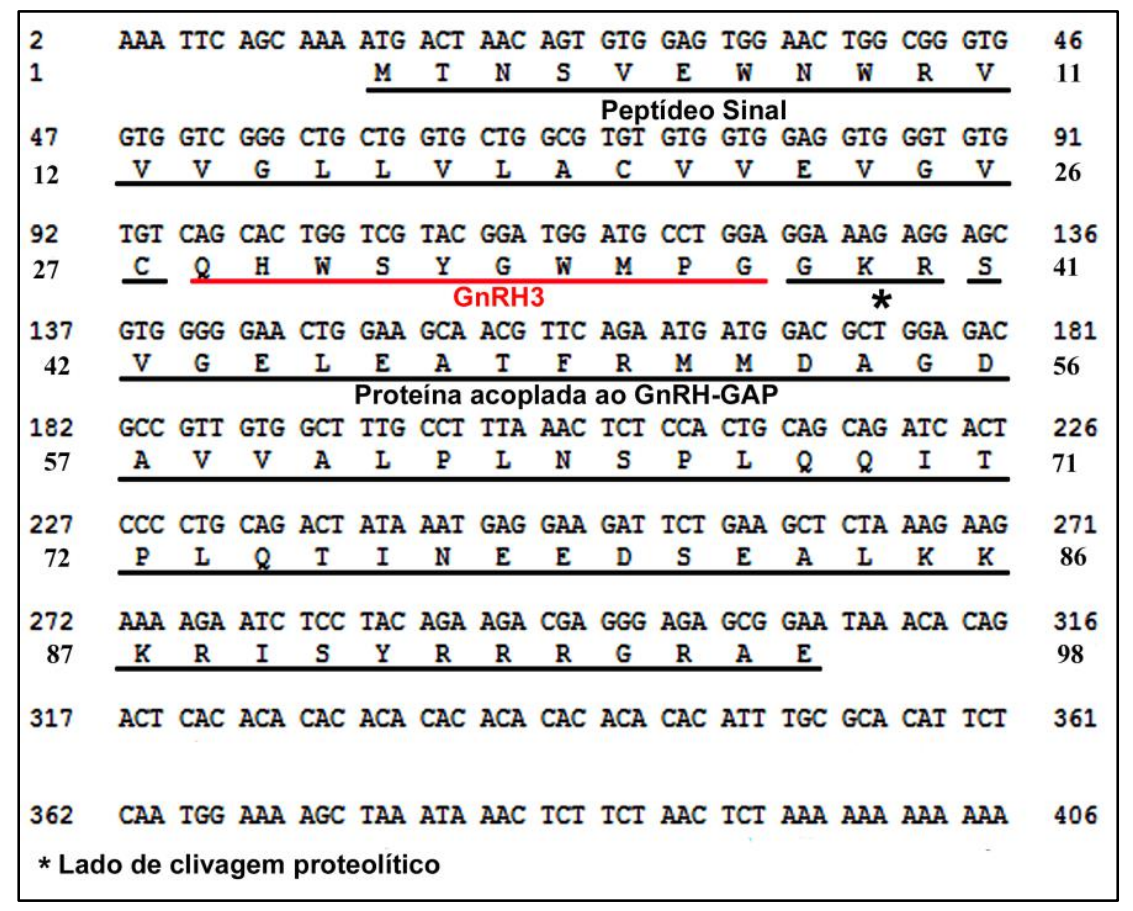

Figura 7. A sequência completa do cDNA e da predita sequência de aminoácidos do preproGnRH3 de Astyanax altiparanae. A sequência total de nucleotídeos apresenta 407pb, sendo 13 pb da região não codificante 5'UTR, 294 pb da predita fase de leitura aberta (ORF) que codifica uma proteína de 98 aminoácidos e 99 pb da região não codificante 3 'UTR.

Usando o algoritmo BLAST (Blastx; National Center for Biotechnology Information) foi observado que a sequência de aminoácidos do preproGnRH3 de Astyanax altiparanae apresenta similaridade com a sequência de aminoácidos do preproGnRH3 de outros teleósteos como: 100\% com preproGnRH3 Astyanax 
mexicanus (Characiformes), 62\% com preproGnRH3 de Cyprinus carpio (Cypriniformes), 54\% com preproGnRH3 de Sparus aurata (Perciforme), 52\% com preproGnRH3 de Verasper moseri (Pleuronectiformes), 54\% com preproGnRH3 de Mugil cephalus (Mugiliformes), $83 \%$ com GnRH3 de Salmo salar (Salmoniformes), 52\% com preproGnRH3 Odontesthes bonariensis (Atheriniformes), 52\% com preproGnRH3 de Oryzias latipes (Beloniformes), 56\% com preproGnRH3 de Monopterus albus (Synbranchiformes) e $42 \%$ com preproGnRH3 de Scleropages jardinii (Osteoglossiformes) (Figura 8).

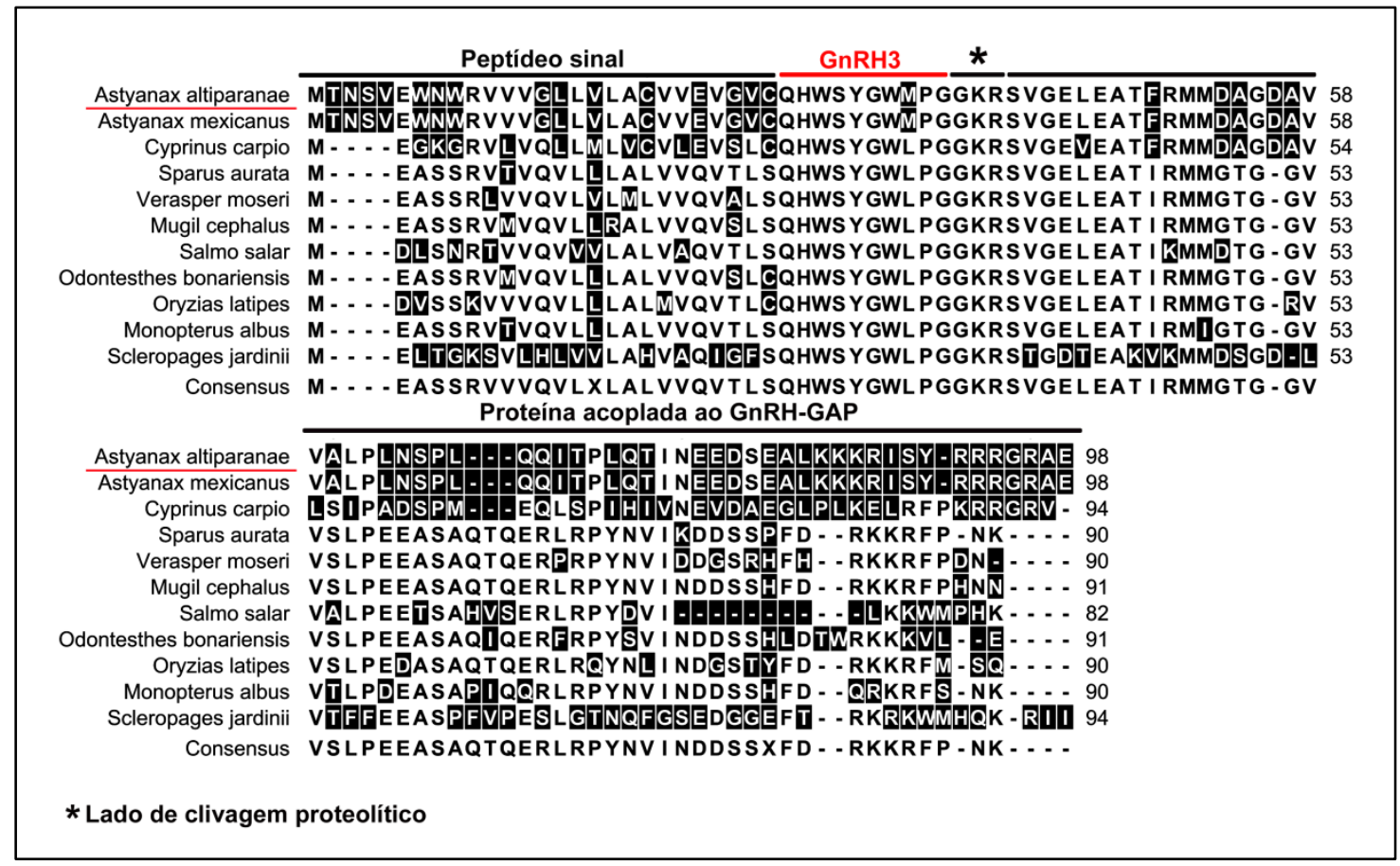

Figura 8. Alinhamento das preditas sequências de aminoácidos a partir do cDNA do preproGnRH3 de Astyanax altiparanae e outras espécies de teleósteos. As sequências foram obtidas no banco de dados do GeneBank. Os resíduos de aminoácidos diferentes estão envoltos por uma caixa da cor preta.

\subsection{Análise filogenética}

\subsubsection{GnRH2}

Foi construída uma árvore filogenética da proteína preproGnRH2 de diversos grupos animais comparando com o preproGnRH2 de Astyanax 
altiparanae, isolado neste trabalho, por meio do método de máxima verossimilhança utilizando o preproGnRH2 de Anguilla japonica para enraizar a árvore.

A análise filogenética indica uma forte relação do preproGnRH2 de Astyanax altiparanae com os preproGnRH2 principalmente de espécies da ordem Siluriformes, assim como de espécies da ordem Cypriniformes (Figura 9). 


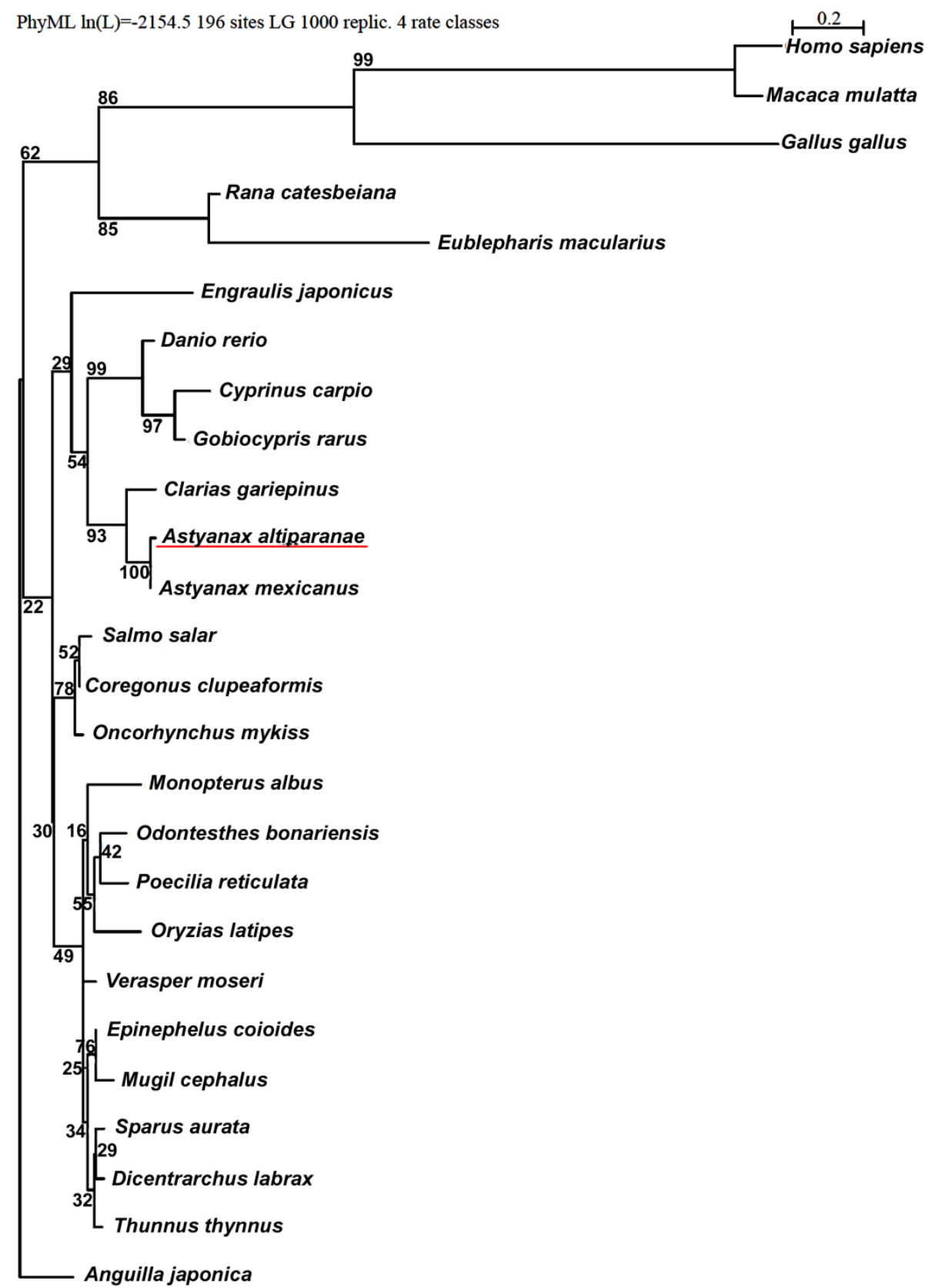

Figura 9. Árvore filogenética baseada no alinhamento de aminoácidos dos preproGnRH2 de vertebrados. Os valores de bootstrap (\%) presente em cada nó são representados por 1000 replicatas.

\subsubsection{GnRH3}

Foi construída uma árvore filogenética da proteína preproGnRH3 de diversos teleósteos comparando com o preproGnRH3 de Astyanax altiparanae, 
isolado neste trabalho, por meio do método de máxima verossimilhança utilizando o preproGnRH3 de Scleropages jardinii para enraizar a árvore.

A análise filogenética indica uma forte relação do preproGnRH3 de Astyanax altiparanae com os preproGnRH3 de espécies da ordem Cypriniformes (Figura 10).

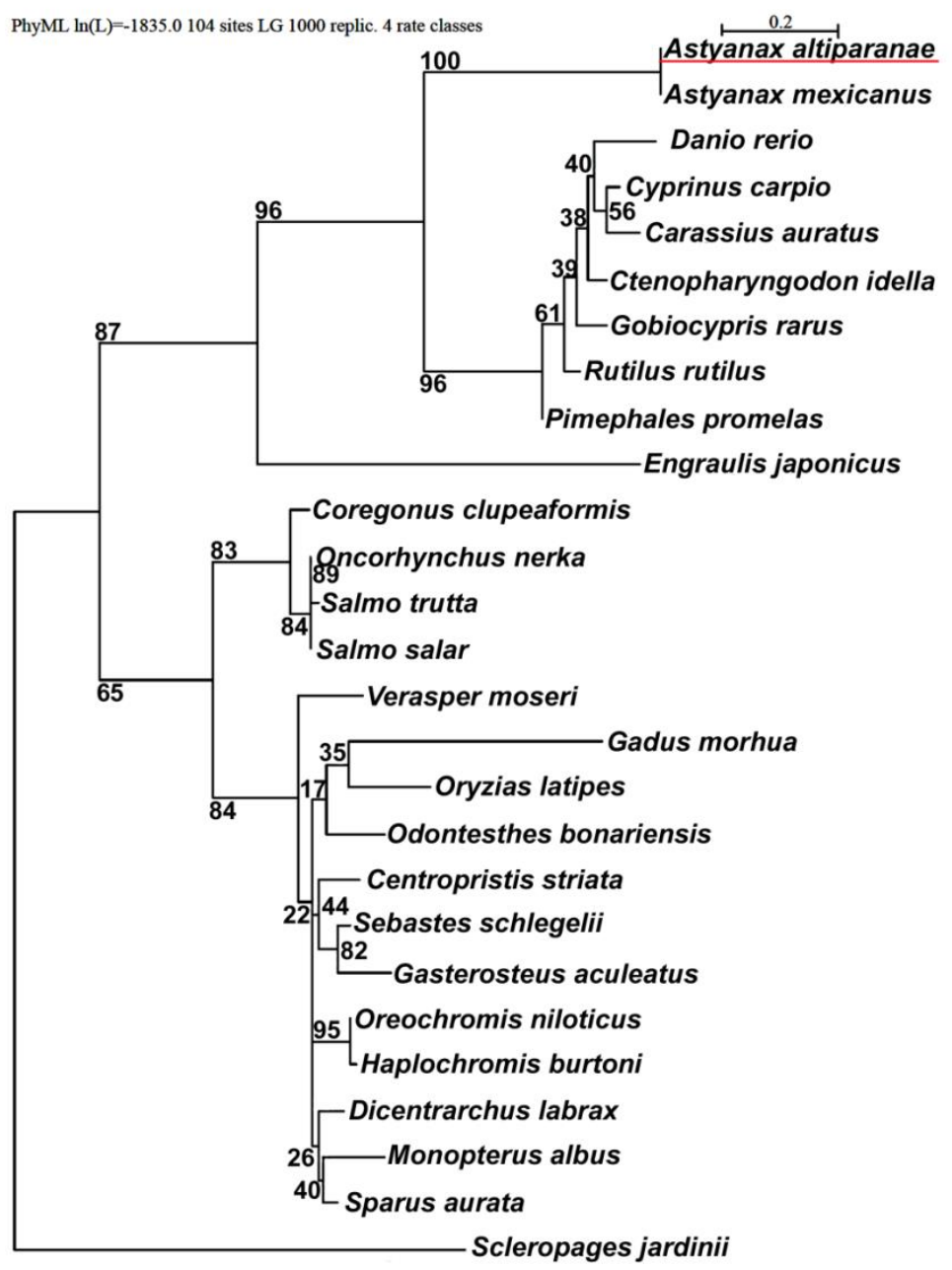

Figura 10. Árvore filogenética baseada no alinhamento de aminoácidos dos preproGnRH3 de teleósteos. Os valores de bootstrap (\%) presente em cada nó são representados por 1000 replicatas.

\subsection{Indução à reprodução por redução do nível da água}

\subsubsection{Razão gonadossomática}


Os animais submetidos à indução à reprodução por redução do nível da água tiveram seu peso total, assim como o peso das gônadas mensurados, e tais medidas nos permitiram estimar a relação gonadossomática (RGS) de ambos os sexos, que é a percentagem que as gônadas representam do peso total do indivíduo de acordo com a expressão RGS= (Pg/Pt) *100 (Vazzoler, 1996).

No entanto, foi observada a variação da relação gonadossomática ao longo do período amostrado somente em fêmeas $(H=16,388 ; p=0,037)$, indicando que as mesmas apresentam alteração significativa no peso das gônadas de acordo com o estímulo reprodutivo, como demonstrado no gráfico abaixo (Figura 11a). Já para machos, a relação gonadossomática não variou $(F=1,806 ; p=0,120)$ ao longo do período amostrado (Figura 11b).

RGS fêmeas

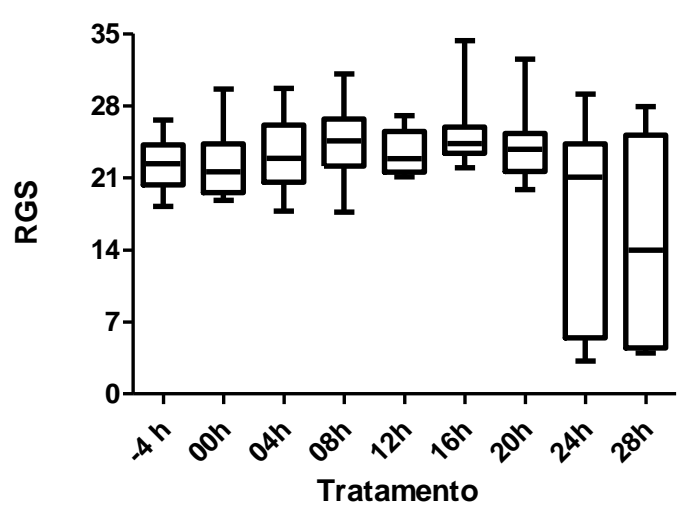

RGS machos

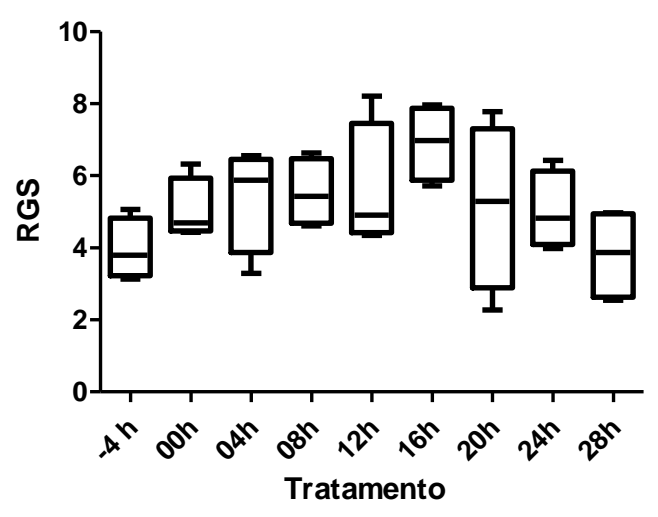

Figura 11. Gráficos demonstrando a variação na razão gonadossomática (RGS) de fêmeas $(H=16.388, p=0.037$ - Kruscal Wallis) em $(A)$ e de machos $(F=1,806$; $\mathrm{p}=0,120$ - One Way ANOVA) em (B).

\subsubsection{Análise morfológica das gônadas}

No período amostrado de 4 horas antes do estímulo reprodutivo às 4 horas após o estímulo reprodutivo, as fêmeas apresentaram os ovários repletos de oócitos vitelogênicos, alguns oócitos pré-vitelogênicos e poucos oócitos iniciais (Figura 12A). No período de 8 horas a 12 horas pós-estímulo, além das 
características encontradas no período anterior foi possível observar alguns complexos pós-ovulatórios (Figura 12B), caracterizando as gônadas na fase aptos à reprodução. No período amostral subsequente, às 16 horas pós-estímulo, foi verificado a presença de muitos oócitos com a quebra da vesícula germinativa, também conhecido como oócito maduro, além de poucos complexos pósovulatórios e oócitos iniciais, indicando, portanto a gônada na fase apto à reprodução, mas em uma subfase mais avançada nomeada como subfase reprodutiva (Figura 12C). Posteriormente, as fêmeas apresentaram seus ovários com características pós-desova, ou seja, com muitos complexos pós-ovulatórios, oócitos iniciais, atresias e alguns oócitos pré-vitelogênicos, caracterizando a fase de regressão (Figura 12D).

Já em machos, no período amostral de 4 horas antes do estímulo reprodutivo até 8 horas pós-estímulo, os testículos apresentaram todas as classes germinativas, porém, principalmente foram observados espermatogônias, espermatócitos primários e a presença de espermatozóides na luz do túbulo caracterizando a gônada na fase apto à reprodução (Figura 12E). Às 12 horas pós-estímulo, os testículos apresentaram-se repletos de espermatozoides na luz do túbulo e poucos cistos de classes celulares mais indiferenciadas foram observados, caracterizando a fase apto à reprodução, porém na subfase mais avançada, a subfase reprodutiva (Figura 12F). E por fim, nos períodos amostrais posteriores foram observados a eliminação parcial dos espermatozoides e a renovação dos cistos de diferentes classes germinativas, retornando a fase aptos à reprodução (Figura 12G). 


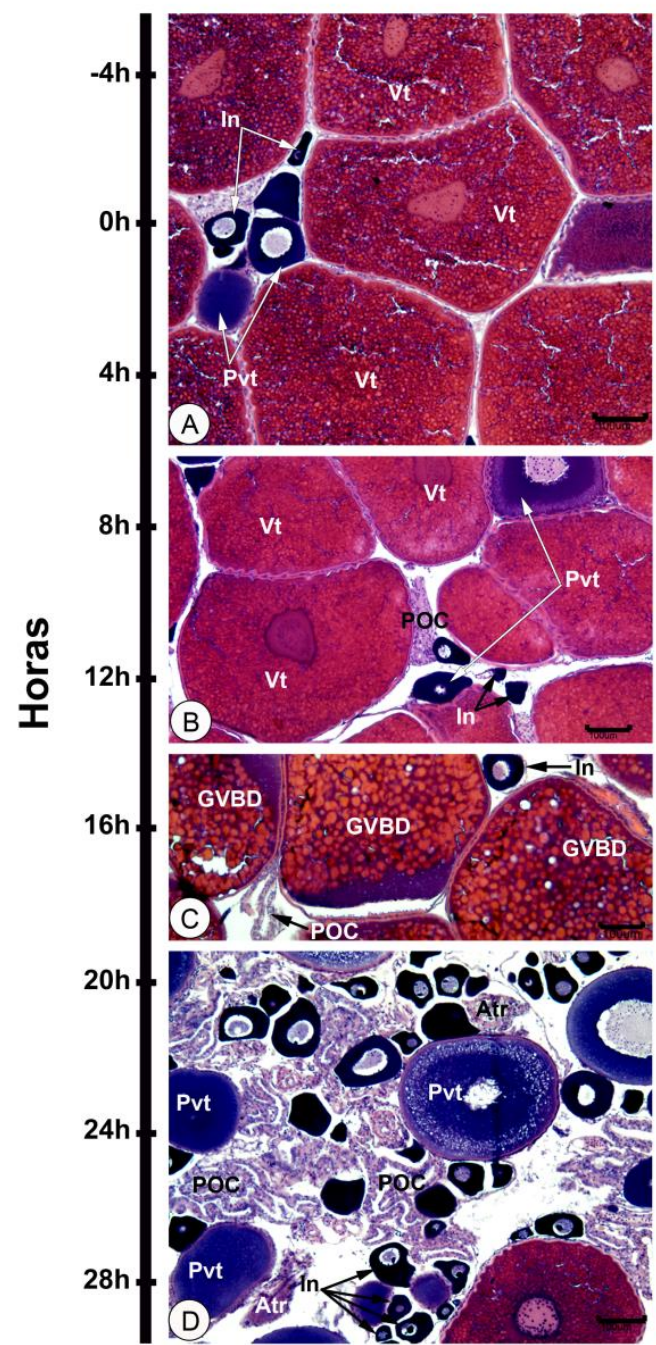

Fêmeas

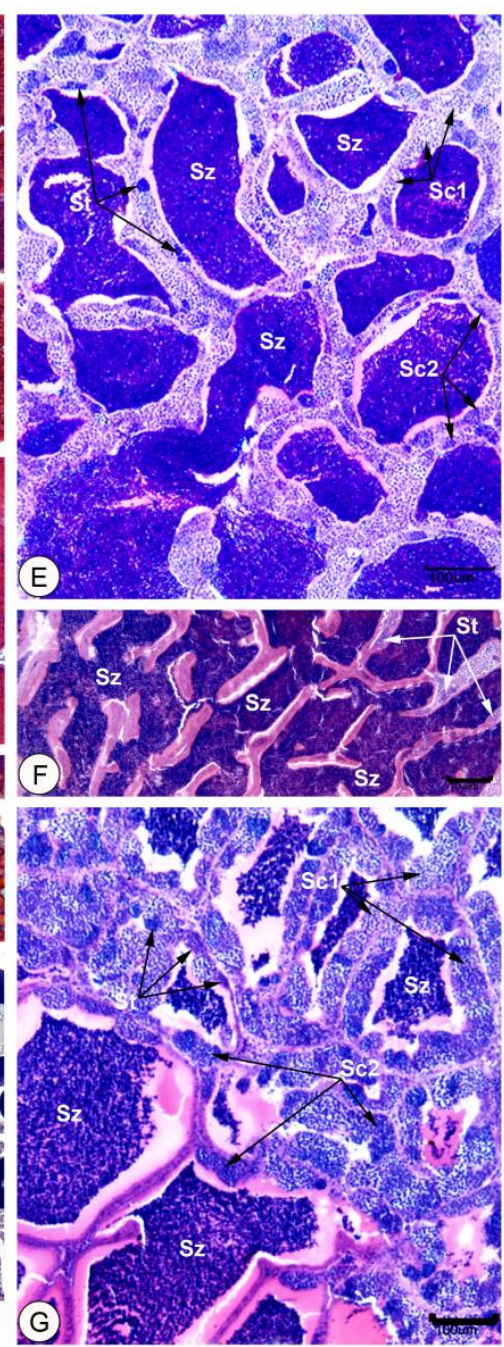

Machos

Figura 12. Fotomicrografias de gônadas de Astyanax altiparanae, submetidos à indução a reprodução por redução do nível da água, demostrando diferentes tempos amostrais (corado com Hematoxilina-Eosina). (A) Ovário na fase apto à reprodução do período de $-4 \mathrm{~h}$ a $4 \mathrm{~h}$; (B) Ovário na mesma fase apto à reprodução, mas com complexos pós-ovulatórios, período de $8 \mathrm{~h}$ e 12h; (C) Ovário na subfase reprodutiva às $16 \mathrm{~h}$ pós-estímulo (D) Ovário durante a fase de regressão no período de 20h a 28h pós-estímulo; (E) Testículos na fase aptos à reprodução do período de 4 horas antes do estímulo à 8 horas após o estímulo; (F) Testículos na subfase reprodutivo no período de $12 \mathrm{~h} ;(\mathrm{G})$ Testículos retornando a fase apto à reprodução no período de $16 \mathrm{~h}$ a $28 \mathrm{~h}$. Abreviações: In - oócito inicial; Pvt - oócitos pré-vitelogênico; Vt - oócito vitelogênico; POC - complexo pós-ovulatório; GVBD oócitos maduros (oócitos com a quebra da vesícula germinativa); Atr - atresia; Sc1 - espermatócito primário; Sc2 - espermatócito secundário; St - espermatídes; $\mathrm{Sz}$ - espermatozoides. 


\subsubsection{Análise quantitativa das classes celulares gonadais}

Os dados quantitativos da análise de proporção das classes celulares por tempo amostral em fêmeas mostrou que houve liberação dos gametas entre o período de 16 horas e 20 horas pós-estímulo. Notou-se às 16 horas pós-estímulo a ocorrência de oócitos maduros, caracterizados pela quebra da vesícula germinativa, e às 20 horas pós-estímulo, estes não foram mais observados, sendo encontrados folículos pós-ovulatórios, indicando que houve a desova (Figura 13). No entanto, o esvaziamento máximo dos ovários ao longo do tempo não ocorreu durante o período amostrado $(H=7,708 ; p=0,463)$ (Figura 13).

\section{Fêmeas}

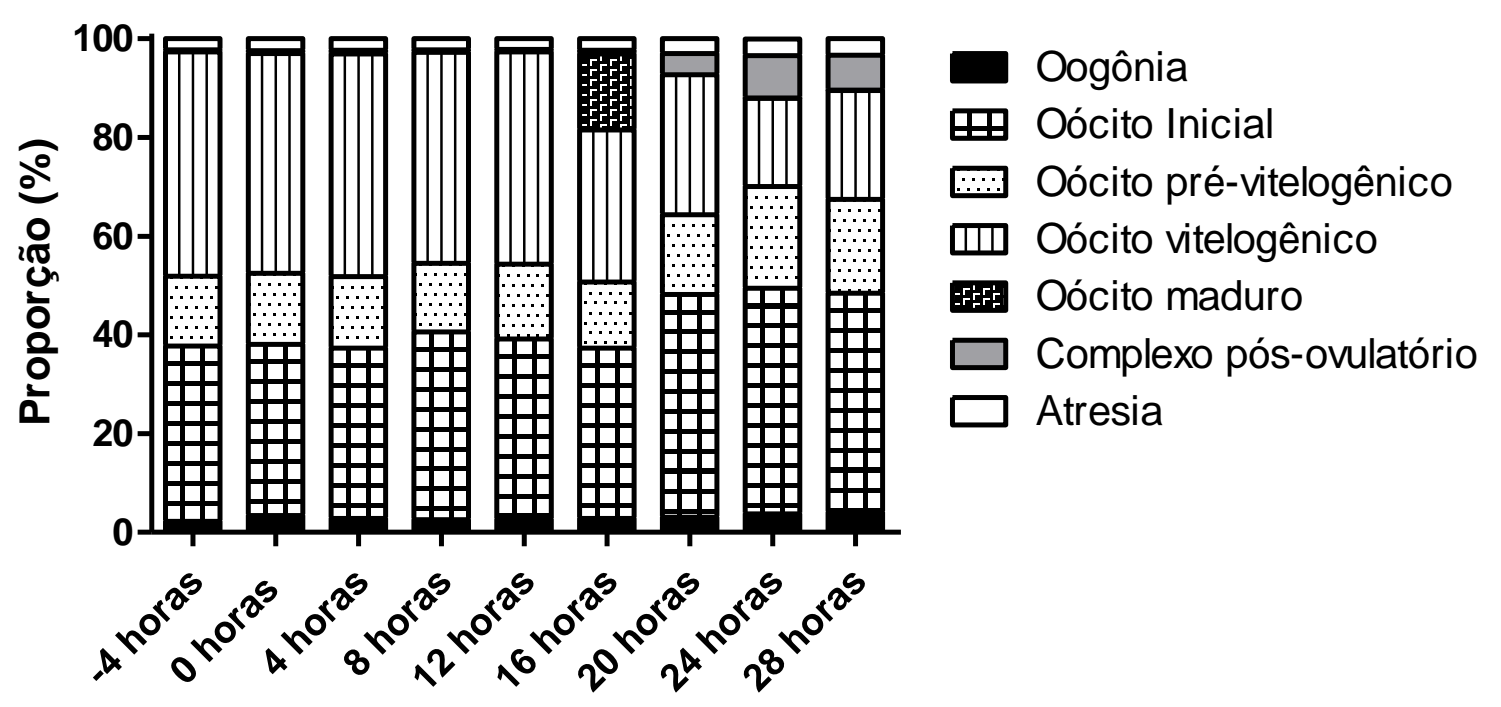

Figura 13. Gráfico demonstrando a análise quantitativa das proporções de classe celulares gonadais de fêmeas.

Em machos, foi visto que às 12 horas pós-estímulo, aproximadamente $80 \%$ do testículo estava ocupado por espermatozoides, e às 16 horas pós-estímulo parte dos espermatozóides foi liberado, encontrando-se $60 \%$ do testículo ocupado pelos mesmos, não apresentando assim, como em fêmeas, o esvaziamento total das gônadas ( $F=1,612 ; p=0,168)$, de forma que espermatozoides estavam sempre presentes nos testículos (Figura 14). 


\section{Machos}

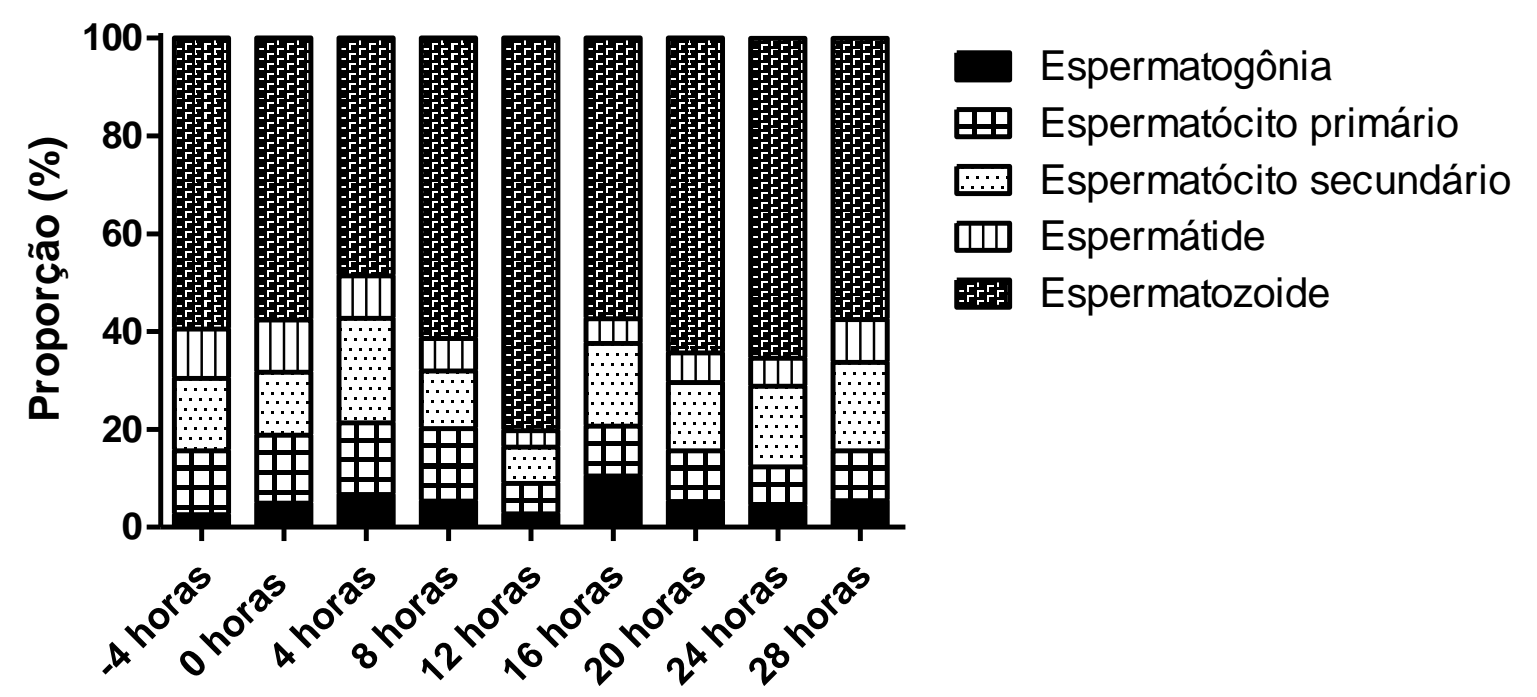

Figura 14. Gráfico demonstrando a análise quantitativa das proporções de classe celulares gonadais de machos.

\subsubsection{Expressão gênica temporal do GnRH2 e GnRH3 em Astyanax altiparanae submetidos à reprodução induzida.}

Foi realizado a análise temporal da expressão gênica do $\mathrm{GnRH} 2$ e do GnRH3 no encéfalo de Astyanax altiparanae durante o estímulo reprodutivo por redução do nível da água, sendo observado que em fêmeas submetidas a esta situação não houve alteração da expressão gênica do $\mathrm{GnRH} 2$ ao longo do período amostrado (Figura 15A) ( $F=2,35 ; p=0,05)$. No entanto, a expressão se mantem mais alta quando comparada com machos submetidos a este mesmo estímulo, os quais apresentam uma expressão gênica do GnRH2 mais baixa durante os períodos amostrados. Contudo, em machos, no momento em que iniciou 0 estímulo reprodutivo houve um aumento significativo da expressão (Figura 12B) $(F=5,55 ; p=0,0004)$, atingindo neste período praticamente os mesmos níveis de mRNA de GnRH2 expressos pelas fêmeas por quase todos os períodos amostrados. 

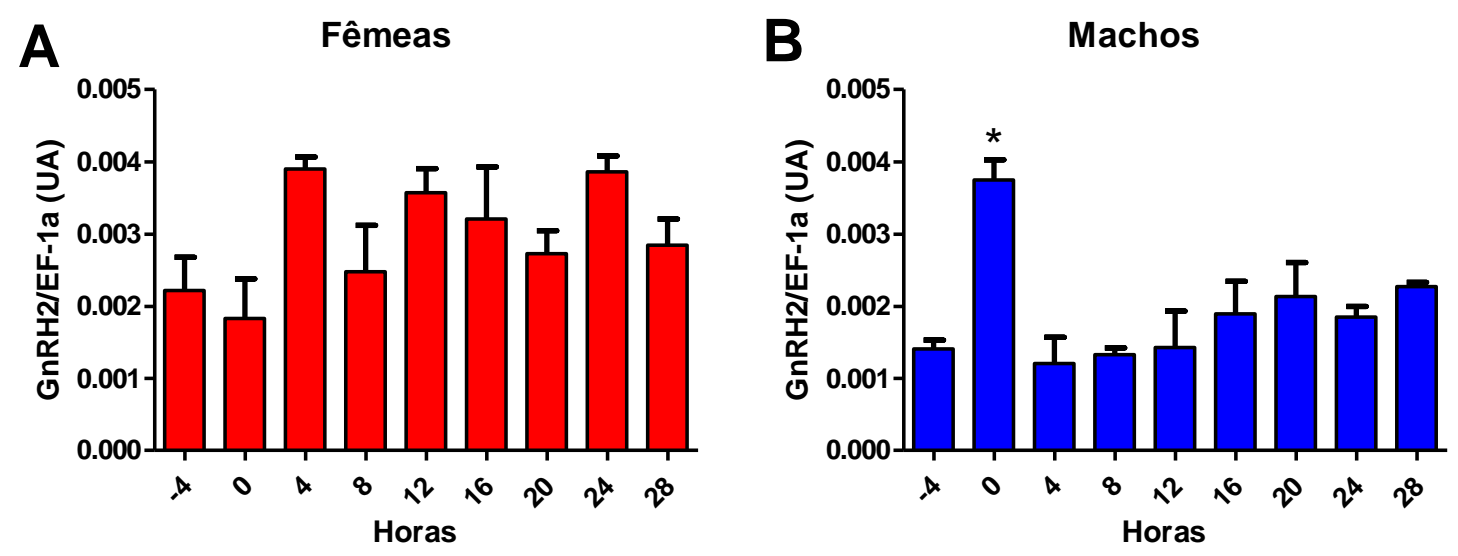

Figura 15. Níveis de expressão de mRNA de GnRH2 no encéfalo de Astyanax altiparanae durante o estímulo reprodutivo por redução do nível da água ( $A$ fêmeas; B- machos). Os níveis de mRNA de GnRH 2 normalizados com os níveis de mRNA de EF-1a (Elongation Factor 1- alpha) no encéfalo de Astyanax altiparanae durante o estímulo reprodutivo foram analisados por qRT-PCR. Valores com asterisco são significativamente diferentes $(p<0,05)$. Os valores são expressos pela média \pm EP $(n=4)$ (Teste One Way ANOVA seguido do pós teste de Tukey).

Os níveis de mRNA de GnRH3 no encéfalo de fêmeas de Astyanax altipanae durante o estímulo reprodutivo foram constante ao longo do período amostrado, incluindo o período de 4 horas antes do estímulo; porém, às 8 horas pós-estímulo reprodutivo, houve um aumento significativo da expressão do mRNA de $\operatorname{GnRH3}(\mathrm{F}=3,91 ; \mathrm{p}=0,004)$ (Figura 16A). Contudo, os níveis de mRNA de GnRH3 em fêmeas se mantiveram mais baixos quando comparados com os níveis de machos, os quais foram mantidos constantes ao longo do período amostrado, havendo uma tendência de aumento da expressão quando comparado ao nível de expressão de 4 horas antes do estímulo ( $F=1,34 ; p=0,28)$ (Figura 16B). 

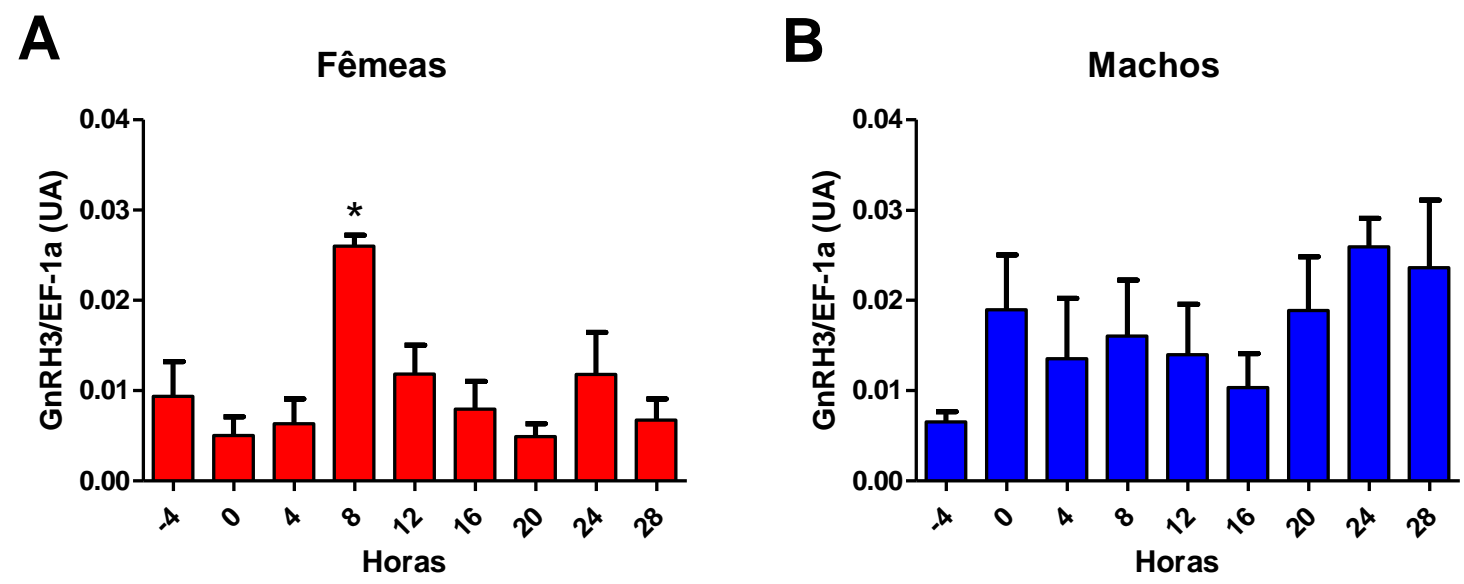

Figura 16. Níveis de expressão de mRNA de GnRH3 no encéfalo de Astyanax altiparanae durante o estímulo reprodutivo por redução do nível da água ( $A$ fêmeas; B- machos). Os níveis de mRNA de GnRH 3 normalizados com os níveis de mRNA de EF-1a (Elongation Factor 1- alpha) no encéfalo de Astyanax altiparanae durante o estímulo reprodutivo foram analisados por qRT-PCR. Valores com asterisco são significativamente diferentes $(p<0,05)$. Os valores são expressos pela média \pm EP $(n=4)$ (Teste One Way ANOVA seguido do pós teste de Tukey).

\subsection{Injeção dos GnRHs - efeito in vivo}

\subsubsection{Razão gonadossomática}

A relação gonadossomática, a qual representa a percentagem do peso das gônadas em relação ao peso total do indivíduo de acordo com a expressão RGS= (Wg/Wt) *100 (VAZZOLER, 1996), não apresentou variação ao longo do período amostrado, quando comparamos os diferentes tratamentos dos GnRHs com o grupo controle (injeção $G n R H 1$ : $F=1,59$ e $p=0,19$; injeção $G n R H 2$ : $F=0,28$ e $p=$ 0,88; injeção GnRH3: $F=0,60$ e $p=0,66$ ) o teste estatístico aplicado foi o Two Way ANOVA, seguido do pós teste de Bonferroni (Figura 17 A, B e C). 

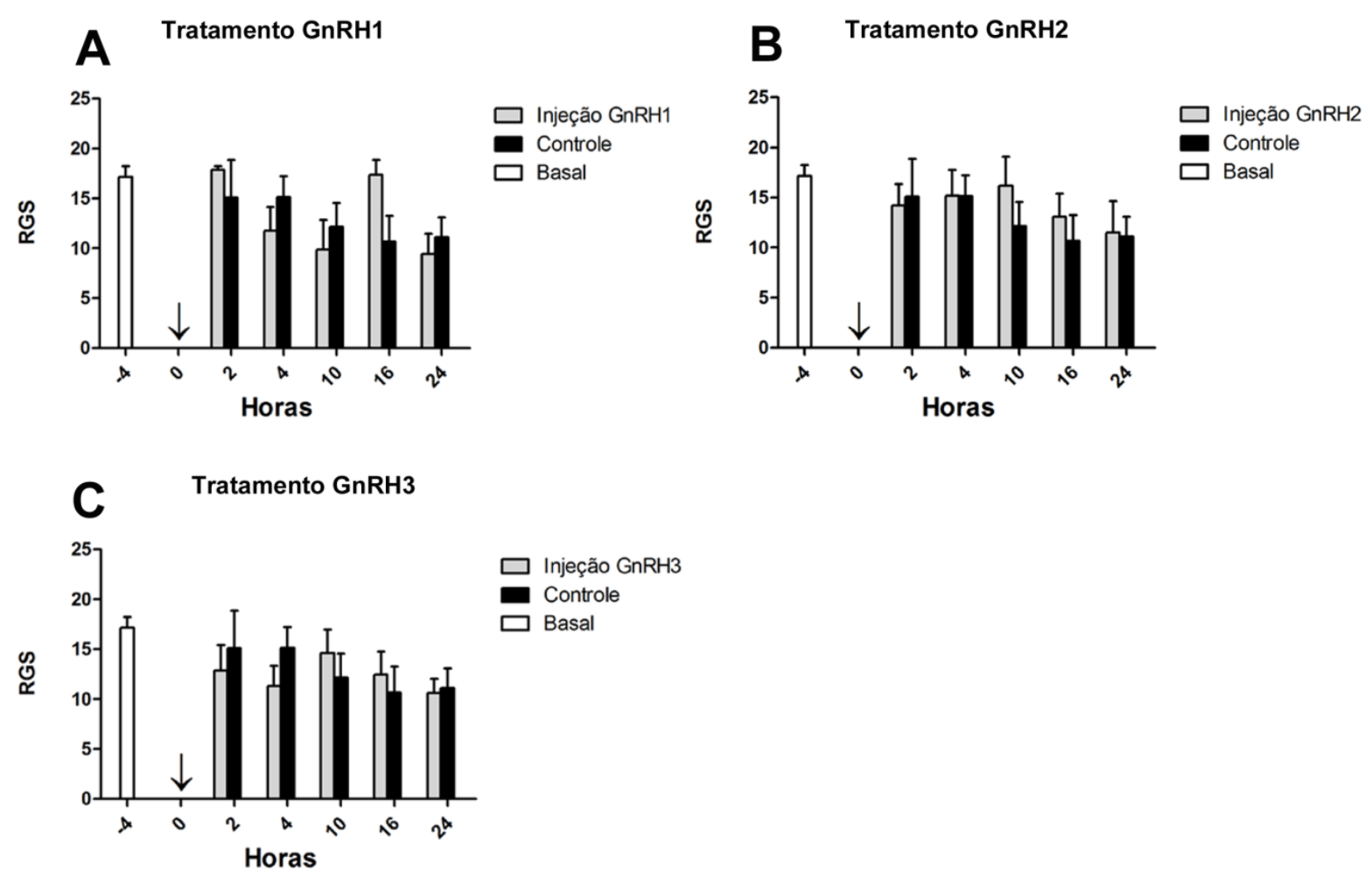

Figura 17. Gráficos demonstrando a variação da relação gonadossomática (RGS) de fêmeas em $(A)$ injetadas com o $G n R H 1$ e do controle $(F=1,59$ e $p=0,19)$ em (B) injetadas com o $\mathrm{GnRH} 2$ e do controle $(F=0,28$ e $p=0,88)$ e em $(C)$ de fêmeas injetadas com $\mathrm{GnRH} 3$ e do controle ( $\mathrm{F}=0,60$ e $\mathrm{p}=0,66)$ (Two-Way ANOVA).

\subsubsection{Análise morfológica das gônadas}

As fêmeas injetadas com os diferentes GnRHs, assim como com a salina, grupo controle, apresentaram as gônadas com diversas classes celulares ao longo do período amostrado. Foram observados oócitos iniciais (In), pré-vitelogênicos (pvt), vitelogênicos $(\mathrm{Vt})$, oócitos atrésicos $(A)$ e complexos pós-ovulatórios (POC), indicando que houve desova como podemos observar na figura 18.

Às 4 horas antes das injeções, ou seja, o grupo basal, os animais apresentaram os ovários repletos principalmente de oócitos vitelogênicos (Vt) e oócitos iniciais (In) (Figura 18), estando, portanto, na fase aptos à reprodução. Nos diversos períodos amostrados dos diferentes tratamentos, a morfologia dos ovários se manteve parecida com a o do grupo basal, estando sempre presentes oócitos vitelogênicos $(\mathrm{Vt})$, oócitos iniciais $(\mathrm{In})$, alguns oócitos pré-vitelogênicos e 
oócitos atrésicos (A), e em alguns períodos amostrados foi possível observar poucos complexos pós-ovulatórios (POC), dessa forma, em geral, estes animais encontravam-se na fase aptos à reprodução, segundo a classificação de BrownPeterson, et al. (2011).

No entanto, às 16 horas pós-injeção do GnRH2, foram vistos complexos pós-ovulatórios com maior frequência nos cortes histológicos (Figura 18N), classificando os animais na fase aptos à reprodução, porém na subfase reprodutiva.

O estágio de desenvolvimento celular dos oócitos maduros, ou seja, com a quebra da vesícula germinativa, não foi observado nos períodos amostrados para os diversos tratamentos. 


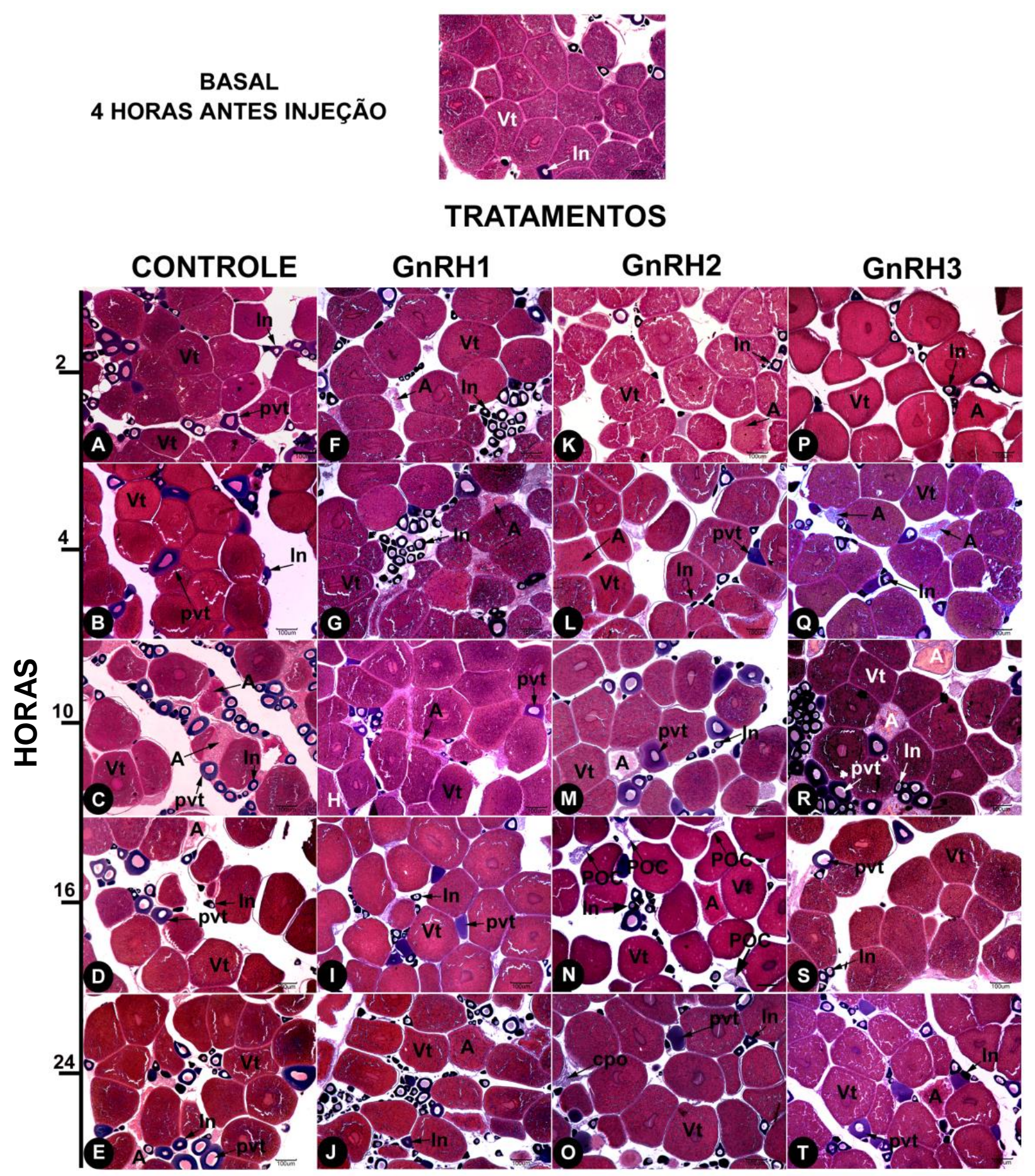

Figura 18. Fotomicrografias de cortes de ovários, corados com H\&E, de Astyanax altiparanae, 4 horas antes do tratamento, assim como dos animais que foram submetidos a injeções dos GnRHs 1,2 e $3(0,5 \mathrm{ug} / \mathrm{g}$ da massa corpórea) e salina no caso do grupo controle. (A-E) ovários do grupo controle de animais injetados com salina. (F-J) ovários do grupo dos animais injetados com $\mathrm{GnRH} 1$. (K-O) ovários do grupo injetado com $\mathrm{GnRH} 2$. (P-T) ovários do grupo injetado com $\mathrm{GnRH3}$. Abreviações: oócitos iniciais (In), pré-vitelogênicos (pvt), vitelogênicos $(\mathrm{Vt})$, oócitos atrésicos $(\mathrm{A})$ e complexo pós-ovulatório (POC). 


\subsubsection{Análise quantitativa das classes celulares gonadais}

A análise comparativa entre as classes celulares gonadais dos animais injetados com GnRH e o grupo controle, mostrou que às 16 horas pós-injeção do GnRH2 as fêmeas apresentaram desova parcial, uma vez que a presença de complexos pós ovulatórios neste período apresentou um aumento significativo quando comparado com o grupo controle ( $F=6,79 ; p=0,004)$ (Figura 19), já as outras classes celulares não apresentaram diferenças ao longo do período coletado e nos grupos tratados (Figura 19 A, B, C, D e F). O teste estatístico utilizado para esta análise foi o Two Way ANOVA seguido do pós-teste de Bonferroni. 
A

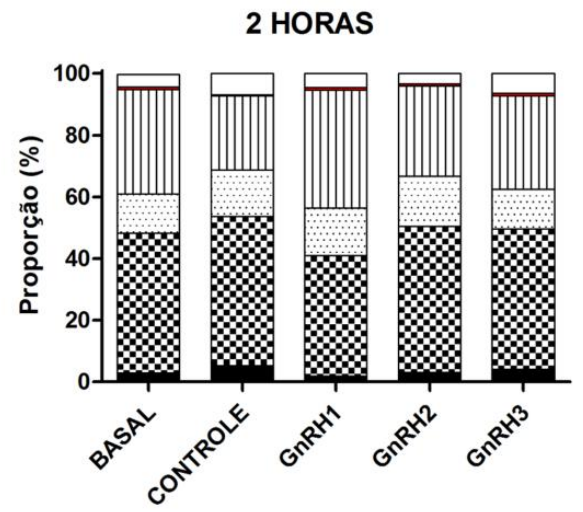

c

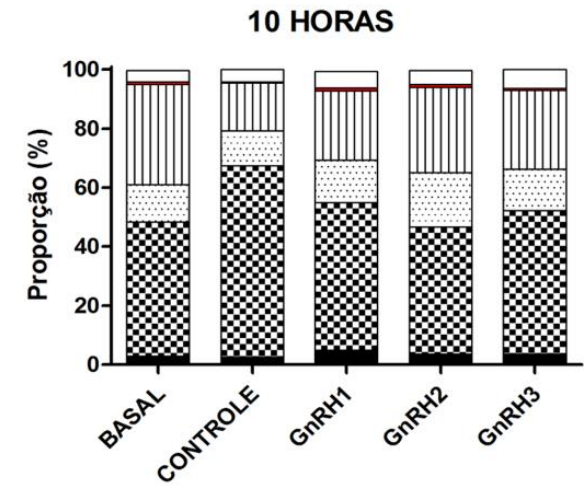

24 Hores

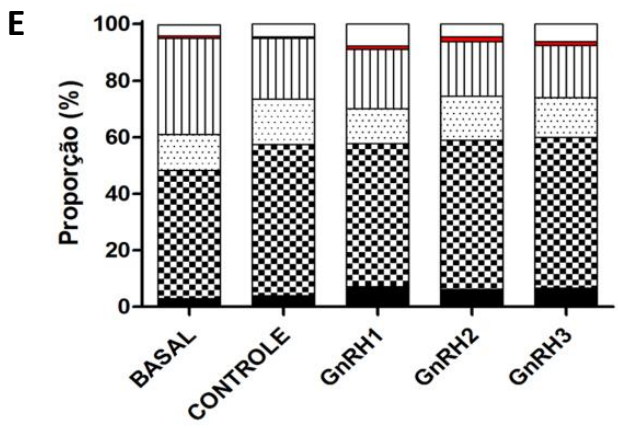

B
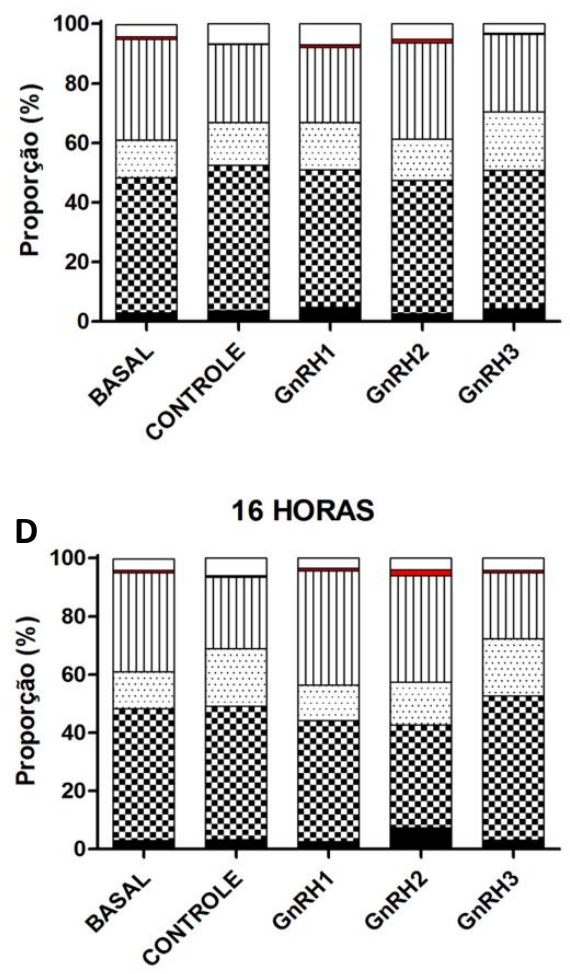

- Oôgonia

$\$$ Oócito inicial

O.... Oócito pré-vitelogênico

एس Oócito vitelogênico

$\square$ Complexo pós-ovulatório

Atrésico

Figura 19. Gráficos demonstrando a análise quantitativa das proporções de classe celulares gonadais de fêmeas dos grupos tratados com GnRHs, do grupo controle e basal em (A) às 2 horas pós-injeção, em (B) às 4 horas pós-injeção, em (C) às 10 horas pós-injeção, em (D) às 16 horas pós-injeção e em (E) às 24 horas pósinjeção. 


\subsubsection{Expressão gênica temporal do $\beta$ FSH E $\beta$ LH em Astyanax altiparanae submetidos ao tratamento com GnRHs.}

Foi realizada a análise temporal da expressão gênica do $\beta F S H$ e do $\beta L H$ na hipófise de fêmeas de Astyanax altiparanae dos grupos injetados com $\mathrm{GnRH}$, controle e basal, e foi observado que independente da forma do $\mathrm{GnRH}$ que foi injetado ( $\mathrm{GnRH1}, 2$ ou 3), todos os tratamentos apresentaram o mesmo padrão, ocorrendo um aumento significativo da expressão do mRNA de $\beta L H$ após 2 horas da injeção do $\mathrm{GnRH}$, quando comparado ao grupo controle e ao basal, e este aumento é mantido por todo o período amostrado, retornando ao nível basal, assim como do controle, às 24 horas. No entanto, a tendência de aumento da expressão está mais proeminente às 2 horas pós-injeção e, apenas no tratamento com $\mathrm{GnRH} 2$. Foi vista também uma tendência de aumento da expressão às 10 horas pós-injeção (Tratamento $\mathrm{GnRH} 1$ - F=5,73, $\mathrm{p}=0,0004$; Tratamento $\mathrm{GnRH} 2$ $F=4,41, p=0,002$; Tratamento GnRH3 - F=7,71, $p=0,0002$ ) (Figura $20 \mathrm{~A}, \mathrm{~B}$ e C).
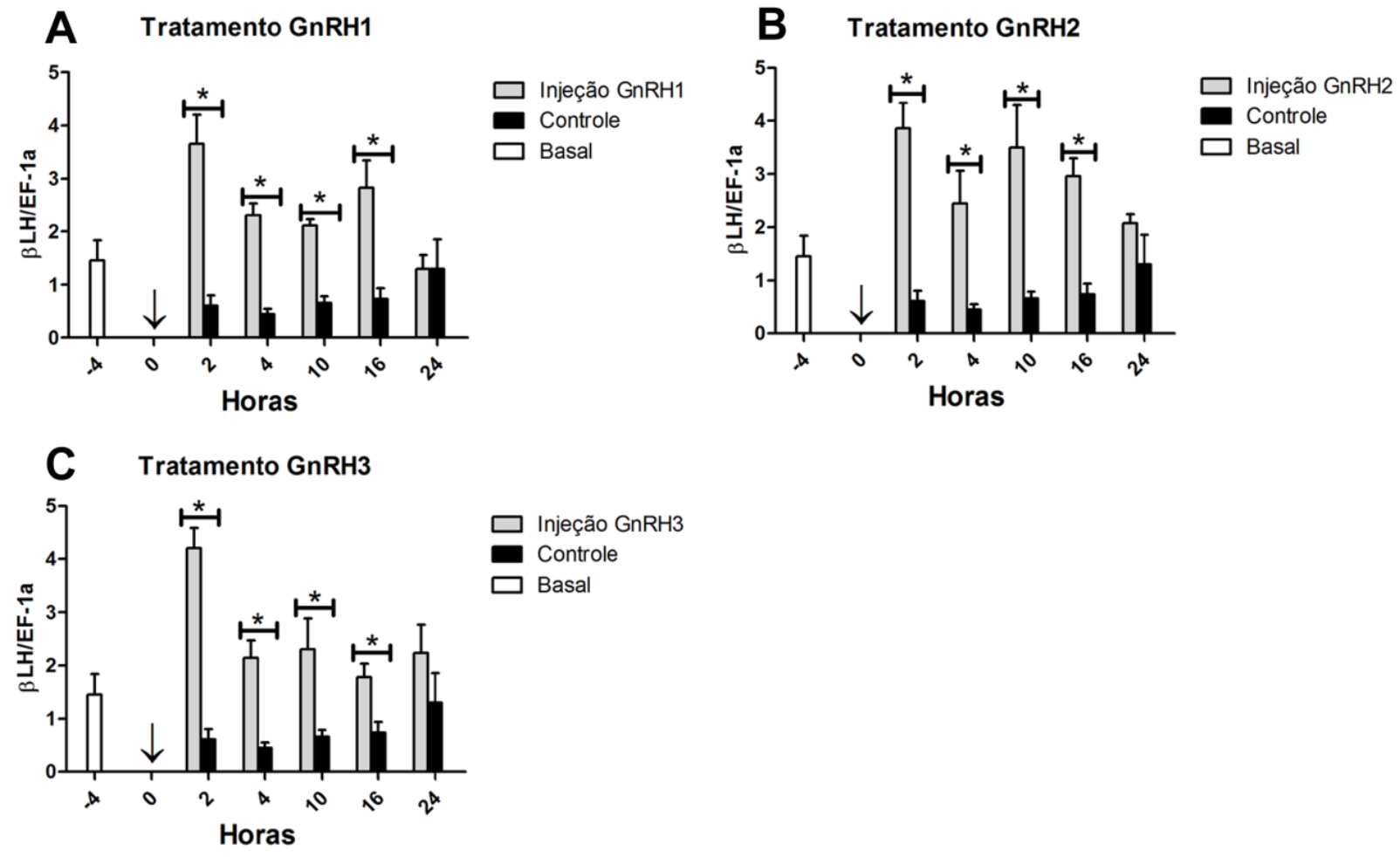

Figura 20. Níveis de expressão de mRNA de $\beta L H$ na hipófise de fêmeas de Astyanax altiparanae submetidas à injeção com $\mathrm{GnRH} 1$ em $(\mathrm{A})$, injeção de $\mathrm{GnRH} 2$ em (B) e injeção de $\mathrm{GnRH} 3$ em (C) comparado aos grupos controle e basal. Os 
níveis de mRNA de $\beta L H$ normalizados com os níveis de mRNA de EF-1a (Elongation Factor 1- alpha) na hipófise de Astyanax altiparanae foram analisados por qRT-PCR. Valores com asterisco são significativamente diferentes $(p<0,05)$. A seta é representativa do momento em que houve a injeção. Os valores são expressos pela média \pm EP $(n=5)$ (Teste Two-Way ANOVA seguido do pós-teste de Bonferroni).

Com relação aos níveis de mRNA de $\beta F S H$ não foram observadas ao longo do período amostrado diferenças na expressão dos grupos injetados quando comparados com os grupos controle e basal (Tratamento GnRH1 - F=1,02; $p=0,41$; Tratamento $\mathrm{GnRH} 2$ - $F=0,43 ; \mathrm{p}=0,77$; Tratamento GnRH3 - $F=0,85$; $p=0,50)$ (Figura 21 A, B e C).
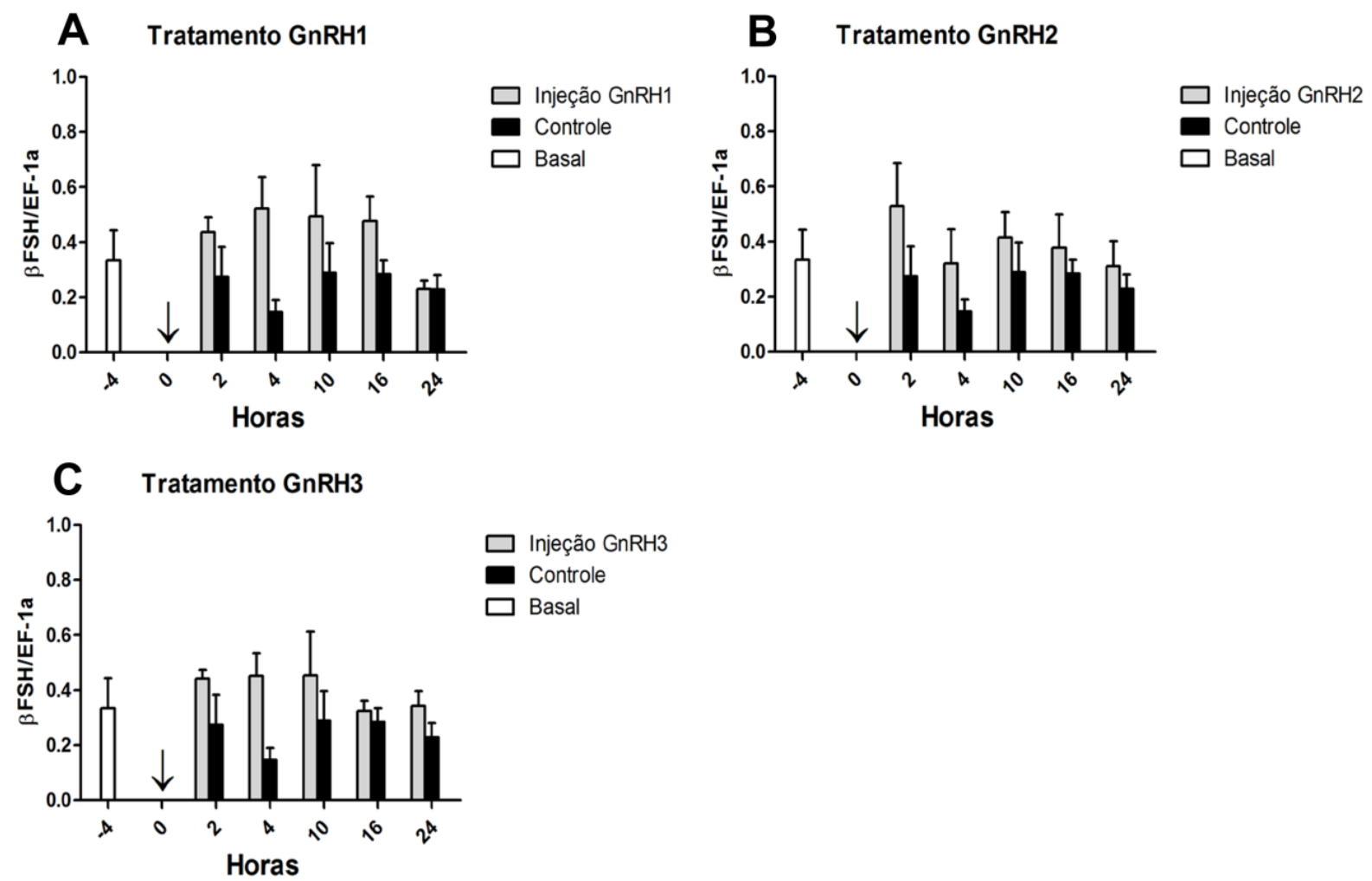

Figura 21. Níveis de expressão de mRNA de $\beta F S H$ na hipófise de fêmeas de Astyanax altiparanae submetidas à injeção com $\mathrm{GnRH} 1$ em $(\mathrm{A})$, injeção de $\mathrm{GnRH} 2$ em (B) e injeção de $\mathrm{GnRH} 3$ em (C) comparado aos grupos controle e basal. Os níveis de mRNA de $\beta F S H$ normalizados com os níveis de mRNA de EF-1 $\alpha$ (Elongation Factor 1- alpha) na hipófise de Astyanax altiparanae foram analisados por qRT-PCR. Não houve diferença significativa entre os animais tratados e 
basais/controles. A seta é representativa do momento em que houve a injeção. Os valores são expressos pela média \pm EP $(n=5)$ (Teste Two-Way ANOVA seguido do pós-teste de Bonferroni).

\subsubsection{Perfil plasmático de $17 \alpha 20 \beta$ dihidroxi-4pregnen-3-one (17,20 DHP) em Astyanax altiparanae submetidos ao tratamento com GnRHs.}

A concentração plasmática do $17 \alpha 20 \beta$ dihidroxi-4pregnen-3-one $(17,20$ DHP), também conhecido como esteróide indutor da maturação (MIS) em fêmeas de Astyanax altiparanae mostrou-se constante durante o período amostrado para os animais injetados com $\mathrm{GnRH} 1$ e $\mathrm{GnRH} 3$ quando comparados com o grupo controle e basal (Tratamento $\mathrm{GnRH} 1$ - $F=1,17 ; \mathrm{p}=0,33$; Tratamento $\mathrm{GnRH} 3$ $\mathrm{F}=0,70 ; \mathrm{p}=0,59$ ) (Figura 22A e $\mathrm{C}$ ). Porém, quando analisamos os níveis de expressão do MIS nos animais injetados com GnRH2, foi observado que às 10 horas pós-injeção estes animais apresentaram um aumento significativo da concentração plasmática do MIS quando comparados com o grupo controle e basal $(F=22,76 ; p<0.0001)$. Ainda, nota-se que existe uma tendência na elevação da concentração do MIS às 4 horas assim como às 24 horas pós-injeção do GnRH2 (Figura 22B). 

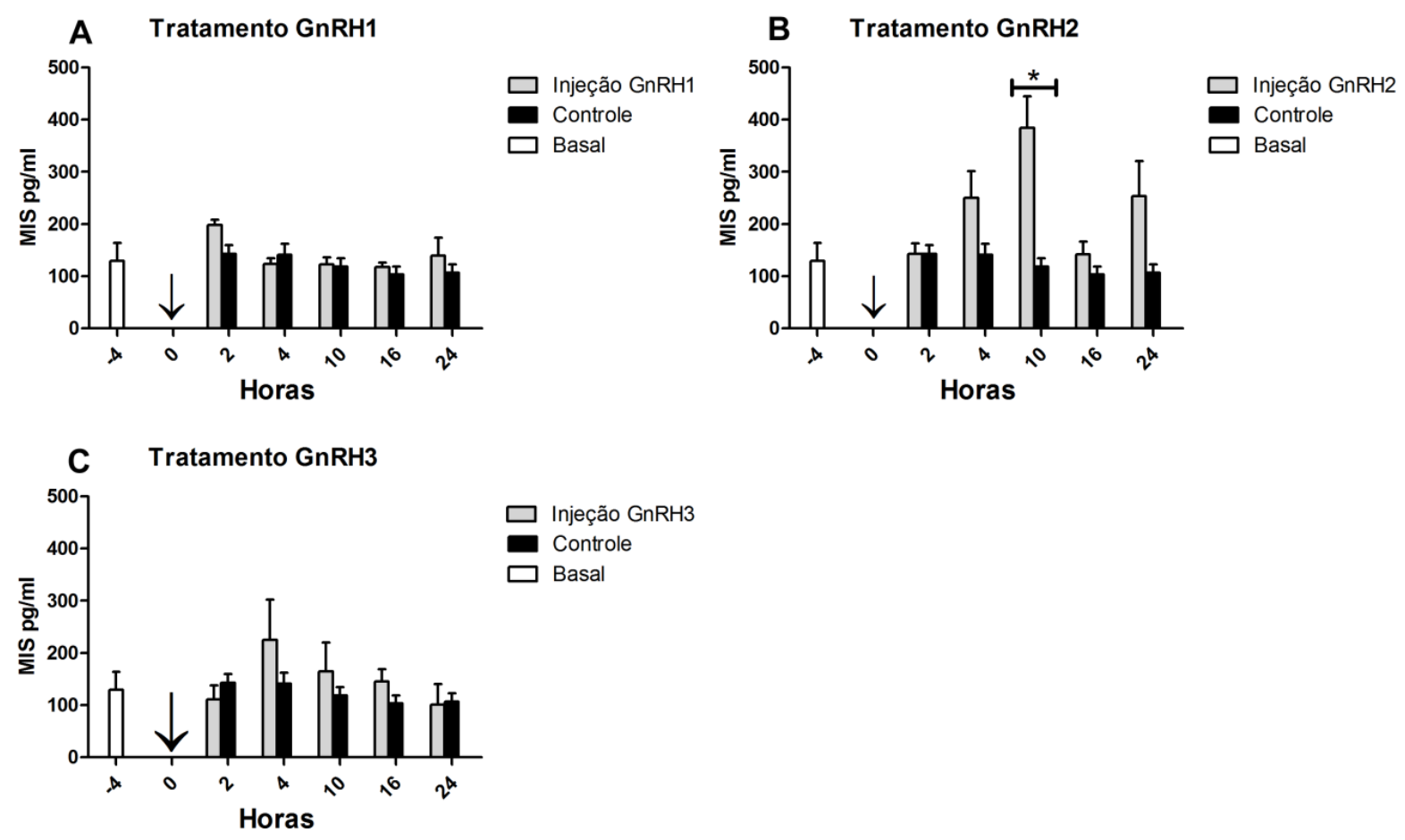

Figura 22. Concentração plasmática temporal de $17 \alpha 20 \beta$ dihidroxi-4pregnen-3one (17,20 DHP) em fêmeas de Astyanax altiparanae submetidas à injeção com GnRH1 em (A), a injeção de GnRH2 em (B) e a injeção de GnRH3 em (C) comparado ao grupo controle e basal. Valores com asterisco são significativamente diferentes $(p<0,05)$. A seta é representativa do momento em que houve a injeção. Os valores são expressos pela média $\pm E P(n=5)$ (Teste Two-Way ANOVA seguido do pós-teste de Bonferroni).

\subsubsection{Validação dos ensaios de ELISA}

Os reagentes utilizados para a dosagem de $17 \alpha, 20 \beta$ dihidroxi-4pregnen-3one foram validados para o plasma de Astyanax altiparanae, e como podemos observar na tabela 2 a amplitude do coeficiente de variação intraensaio foi de 0 $20,7 \%$ e amplitude do coeficiente de variação interensaio foi e 1,06 - 21,31\%. 
Tabela 2. Amplitude do coeficiente de variação intraensaio e interensaio, e número amostral utilizado para a validação do ensaio de $17 \alpha, 20 \beta$ dihidroxi4pregnen-3-one (17,20 DHP) em plasma de Astyanax altiparanae.

\begin{tabular}{lcc}
\hline & Amplitude do coeficiente de variação & Número de amostras testadas \\
\hline intraensaio & $0-20,7$ & 139 \\
interensaio & $1,06-21,31$ & 19 \\
\hline
\end{tabular}

\section{DISCUSSÃO}

\subsection{Sequências dos cDNAs dos preproGnRH2 e preproGnRH3 de Astyanax altiparanae}

Estudos indicam o GnRH como um bom marcador de estudos em evolução (KAVANAUGH; NOZAKI; SOWER, 2008; SILVER et al., 2004), no entanto inúmeras sequências desta molécula ainda não foram descritas em diversas espécies, principalmente quando se trata de espécies neotropicais, sendo este 0 primeiro estudo a isolar sequências dos cDNAs dos preproGnRHs de uma espécie da ordem Characiformes, Astyanax altiparanae, embora recentemente foi descrito o genoma do Astyanax mexicanus apresentando tamanho de 954 Mb (MCGAUGH et al., 2014).

No presente trabalho foi isolado o preproGnRH2 e preproGnRH3 de $A$. altiparanae; ainda, fizemos várias tentativas para isolar o preproGnRH1 nesta espécie, nas quais não obtivemos sucesso. Como recentemente foi descrito o genoma de uma espécie do mesmo gênero, citado acima, tentamos por meio de sintenia, já que o gene do GnRH1 não foi anotado naquele genoma, encontrar a sequência do preproGnRH1, porém não obtivemos êxito. Tal fato sugere que o $A$. altiparanae, assim como o A. mexicanus, não possui o $\mathrm{GnRH} 1$.

Todos os GnRHs são constituídos por um grande precursor, preproGnRH, o qual inclui um peptídeo sinal (23-26 aminoácidos), o peptídeo $G n R H$ biologicamente ativo, o lado de clivagem proteolítico (gly-lys-arg) e um peptídeo associado ao GnRH (GAP- aproximadamente 48-69 aminoácidos) (AN et al., 2008; CAMPOS et al., 2011; KAVANAUGH; NOZAKI; SOWER, 2008; KIM et al., 2011; SILVER et al.. 2004). 
Algumas diferenças no tamanho dos preproGnRHs de Astyanax altiparanae foram observadas quando comparadas com os demais preproGnRHs citados acima, onde o peptídeo sinal do preproGnRH3 apresentou 27 aminoácidos e a proteína acoplada ao $\mathrm{GnRH} 2$ apresentou 47 aminoácidos, no entanto a quantidade de aminoácidos que difere entre os preproGnRHs do A. altiparanae para os demais é ínfima. Contudo, estas diferenças tornam-se uma característica dos preproGnRHs de $A$. altiparanae, que ainda não havia sido descrita em uma espécie da ordem Characiformes.

Com relação à sequência do cDNA, há uma grande variedade no tamanho dos preproGnRHs, sendo que o preproGnRH2 de Sparus sarba apresentou 557 pb (HU et al., 2008), de Acanthopagrus schlegeli 258 pb (AN et al., 2008) e de Danio rerio 655 pb (KUO et al., 2005), já o preproGnRH3 de Sparus sarba apresentou 483 pb (HU et al., 2008), de Acanthopagrus schlegeli 273 pb (AN et al., 2008) e de Danio rerio 430 pb (KUO et al., 2005). O preproGnRH2 de $A$. altiparanae apresentou o tamanho da sequência semelhante ao de Danio rerio com $612 \mathrm{pb}$, assim como o preproGnRH3 com 407pb, sendo as ordens dessas espécies consideradas grupos irmãos.

A variação entre o número de pares de bases dos preproGnRHs entre as espécies provavelmente é devida à técnica para isolar os fragmentos de interesse, onde as regiões não codificantes 5'UTR e 3'UTR nem sempre são isoladas completamente, por isso é melhor usar para comparações as sequências preditas de aminoácidos ou a fase de leitura aberta.

Quando se comparam as regiões dos preproGnRHs ortólogos é visto $100 \%$ de similaridade entre os decapeptídeos, exceto para o $\mathrm{GnRH} 1$. Já a proteína acoplada ao $\mathrm{GnRH}$ e o peptídeo sinal apresentam menor similaridade, isto para a predita sequência de aminoácidos, já quando se compara a sequência de nucleotídeos observa-se maior similaridade na porção codificante do $\mathrm{GnRH}$, no entanto esta raramente alcança os $100 \%$.

A diferença na conservação das regiões do preproGnRH evidencia que a pressão evolutiva é diferencial dentro do gene, sendo que a conservação seletiva do decapeptídeo $\mathrm{GnRH}$ mostra uma significância funcional, assim como uma 
baixa tolerância a alterações estruturais durante a evolução (OKUBO; NAGAHAMA, 2008).

O grupo ortólogo dos decapeptídeos GnRH1 é o único que apresenta variação entre as moléculas, principalmente na posição $5 \mathrm{com}$ a presença de histidina, tirosina ou fenilalanina, na posição 7 com leucina ou metionina e na posição 8 com a presença de asparagina, serina ou arginina. Já os grupos ortólogos dos decapeptídeos GnRH2 e GnRH3 apresentam se altamente conservados entre os teleósteos, sendo o $\mathrm{GnRH} 2$ caracterizado pela presença da histidina $(H)$, triptofano $(W)$ e tirosina $(Y)$ nas posições 5,7 e 8 respectivamente. Já o GnRH3 é caracterizado pela a presença de tirosina (Y), triptofano (W) e leucina (L) nas posições 5, 7 e 8 respectivamente (TUZIAK; VOLKOFF, 2013).

Interessantemente a sequência do decapeptídeo $\mathrm{GnRH} 3$ de $A$. altiparanae assim como de $A$. mexicanus, mostrou uma diferença na posição 8 dos aminoácidos onde se encontra a metionina, ao invés de leucina como nos GnRH3 de outras espécies, mas as outras posições se mantem características. Este fato precisa ser melhor investigado com relação a outras espécies de Characiformes para vermos se é algo característico da ordem ou talvez um fato isolado entre o gênero. Contudo a posição divergente não está relacionada ao efeito biológico do peptídeo a qual se localiza na região mais estável da molécula 1-3 (SHERWOOD et al., 1986), no entanto não se sabe qual a consequência que esta mudança pode ocasionar na conformação da proteína ou até mesmo na sua ligação ao receptor, para isso é necessário realizar estudos funcionais.

Com relação à sequência predita de aminoácidos do preproGnRH3 de $A$. altiparanae foi observado $100 \%$ de identidade da predita sequência do preproGnRH3 de $A$. mexicanus, porém, quando comparamos a sequência do cDNA esta similaridade decresce apresentando $97 \%$. Para a predita sequência de aminoácidos do preproGnRH2 foi observado $99 \%$ de similaridade com 0 preproGnRH2 de A. mexicanus assim como para a sequência de nucleotídeos. Tal informação mostra a alta conservação entre os preproGnRHs da mesma ordem, contudo é necessário que mais descrições do preproGnRHs da ordem Characiformes sejam feitas para afirmarmos a alta similaridade na mesma ordem, 
já que para Perciformes, como em Acanthopagrus schlegeli é visto que a predita sequência de aminoácidos do preproGnRH3 apresenta $100 \%$ de similaridade com o preproGnRH3 de Sparus aurata, 98\% com Pagrus major e 95\% com Thunnus thynnus, já para o preproGnRH2 é visto $98 \%$ de similaridade com o preproGnRH2 de Sparus aurata e $96 \%$ com o de Thunnus thynnus (AN et al., 2008) sendo todas as espécies comparadas pertencentes a ordem Perciformes.

Os dados obtidos para as similaridades entre as sequências dos preproGnRHs, mostraram que o preproGnRH2 de Astyanax altiparanae apresentou maior similaridade com o preproGnRH2 das demais espécies, quando comparado com as similaridades apresentadas com o preproGnRH3. Este resultado vai de encontro com o fato do $\mathrm{GnRH} 2$ ser a forma mais conservada como proposto por diversos autores (DUBOIS et al., 2002, MILLAR et al., 2004; PAWSON et al., 2003; SCHNEIDER; RISSMAN, 2008; XIA et al., 2014).

As análises filogenéticas mostram que a estrutura de aminoácidos do preproGnRH2 coloca o $A$. altiparanae próximo a espécies da ordem Siluriformes, seguido pela proximidade com espécies da ordem Cypriniformes e o preproGnRH3 mostrou proximidade com os das espécies da ordem Cypriniformes. Esses resultados são consistentes com as similaridades apresentadas entre as sequências dos preproGnRHs dessa ordem, assim como com o cladograma demonstrado por NELSON (2006) construído em cima de dados morfológicos de vertebrados, onde no grupo de teleósteos as ordens Cypriniformes, Siluriformes e Characiformes estão intimamente agrupadas. Tais dados sugerem uma alta conservação dos preproGnRHs de Astyanax altiparanae, o que confirma a consideração dessa molécula ser um bom marcador de estudos em evolução (KAVANAUGH; NOZAKI; SOWER, 2008; SILVER et al., 2004).

\subsection{Indução à reprodução por redução do nível da água}

A redução do nível de água juntamente com água corrente e alta densidade dos animais que se encontram na fase aptos à reprodução podem ser considerados estressantes aos animais, no entanto conferiram uma estratégia 
adotada eficaz para a indução à reprodução de Astyanax altiparanae, como foi também observado em Clarias batrachus, onde mudanças nos níveis da água induziram a ovulação (TARNCHALANUKIT, 1987).

Sabe-se que o estresse, na maioria das vezes, desencadeia uma resposta negativa no sucesso reprodutivo, tanto para machos como para fêmeas (CLEARY; PANKHURST; BATTAGLEN, 2007; CONSTEN et al., 2002; MOSCONI et al., 2006). O principal fator envolvido na resposta negativa ao estresse é o cortisol, que em fêmeas parece inibir a síntese de vitelogenina, a qual é modulada por estrógenos (BERG; MODIG; OLSSON, 2004; PANKHURST; VAN DER KRAAK, 2000). Em machos, o cortisol inibe a síntese de andrógenos, retardando a espermatogênese (CONSTEN et al., 2002; OZAKI et al., 2006).

No entanto, estes efeitos deletérios estão associados a prolongados estímulos de agentes agressores, resultando em altos níveis de cortisol plasmático (BAYUNOVA; BARANNIKOVA; SEMENKOVA, 2002; SCHRECK, 2010). Em animais em fases finais do ciclo reprodutivo, o estresse parece apresentar um efeito positivo na reprodução (MILLA et al., 2009; SMALL, 2004; WESTRING et al., 2008). Este efeito pode ser observado principalmente em fêmeas, onde foi demonstrado que o tratamento com corticosteroides (cortisol, 11-deoxycortisol e 11-deoxycorticosterona) induziu a ovulação em diversas espécies de peixes (GOETZ; THEOFAN, 1979, HAIDER; RAO, 1994, SMALL, 2004).

Ainda, em machos, foram observados altos níveis de cortisol em espécimes de Morone saxatilis em cativeiro, o que ocasionou uma espermiação precoce e a exibição de um período de espermiação prolongado (CASTRANOVA; KING; WOODS, 2005). Este fato pode explicar o que foi observado em machos de Astyanax altiparanae, os quais responderam ao estímulo de estresse hídrico anteriormente às fêmeas, sugerindo que os machos têm maior sensibilidade a uma situação de estresse.

É importante salientar que, em geral, o processo natural de reprodução demanda uma alta taxa enérgica para o comportamento de corte, para a maturação dos gametas e, principalmente, para espécies de peixes migradoras (SCHRECK, 2010), como é o caso do Astyanax altiparanae. Isto sugere que o 
estresse hídrico pode ter sido essencial para atingir uma demanda energética favorável à reprodução, mimetizando uma resposta fisiológica como a esperada em reprodução natural.

Esta demanda energética aparentemente é mais expressiva em fêmeas, porque a maturação ovariana e fecundidade do peixe estão ligadas diretamente às reservas de energia (MILTON; BLABER; RAWLINSON, 1994). A disponibilidade de energia pode causar variações na produção de ovos (COWARD; BROMAGE, 1999; MARSHALL et al., 1999) com prováveis impactos sobre a alometria do ovário (SOMARAKIS et al., 2004) e, consequentemente, na relação gonadossomática (RGS) dos espécimes. Isto pode explicar o fato de que em fêmeas de $A$. altiparanae ocorreu variação na RGS, enquanto em machos não houve variação. Além disso, houve um aumento do volume celular durante a oogênese, o que parece ser significativo para a apresentação de uma variação da RGS ao longo do período amostrado.

Somado à RGS, há o fato de os espécimes em ambos os sexos não apresentarem um esvaziamento completo da gônada, apesar de ter sido constatado um momento de desova. Isso pode estar relacionado à estratégia reprodutiva desta espécie, sendo que estratégias reprodutivas compreendem um conjunto de características que as espécies devem apresentar para ter sucesso na reprodução (VAZZOLER, 1996). No entanto, para o gênero Astyanax, há divergências em descrições da reprodução na literatura. Por exemplo, espécimes de Astyanax bimaculatus do rio Ivaí, Paraná, apresentam desova parcelada, ocorrendo entre novembro e fevereiro (AGOSTINHO et al., 1984). Já NOMURA (1975), estudando esta espécie no Rio Mogi-Guaçu, São Paulo, observou que a desova é total, ocorrendo entre novembro e dezembro. Segundo RODRIGUES et al. (1992), Astyanax bimaculatus da represa de lbitinga apresenta uma desova total e a reprodução é descontinua, periódica e anual, com maior intensidade reprodutiva no bimestre de dezembro-janeiro.

O mesmo pode ser observado para Astyanax altiparanae, que foi analisado por LIZAMA e AMBROSIO (2002) por meio de fator de condição, e constatada a presença de três períodos reprodutivos: agosto/setembro, novembro/janeiro e 
março. No entanto, quando observadas às variações em níveis mais precisos, como a caracterização histológica realizada no presente trabalho, é possível observar que esta espécie, em condições de cativeiro, apresenta desova parcelada, com desenvolvimento assincrônico na estação reprodutiva. Este dado corrobora ao observado em Astyanax scabripinnis, o qual apresentou desova do tipo parcelada, com desenvolvimento assincrônico, tendo o período de novembro a abril com a maior atividade reprodutiva (PEREIRA FILHO et al., 2011).

O sucesso reprodutivo obtido com a estratégia adotada de redução do nível água e alta densidade dos animais, provavelmente tenha se dado devido a uma cascata hormonal que foi ativada e dentre os hormônios envolvidos nesse processo reprodutivo foram analisados no presente trabalho o $\mathrm{GnRH} 2$ e o GnRH3.

$\mathrm{O} \mathrm{GnRH} 2$, localizado no mesencéfalo e presente na maioria dos vertebrados é a forma mais conservada dentre os grupos parálogos, indicando que a pressão seletiva exercida no GnRH2 foi menor, o que provavelmente signifique que ele exerça uma importante função (KASTEN et al.,1996; KING; MILLAR, 1991, 1992, SHERWOOD; LOVEJOY; COE, 1993).

No entanto, a função do peptídeo altamente conservado GnRH2 ainda está em debate, sendo entre diversas funções propostas para o GnRH2 o seu envolvimento no comportamento sexual (MILLAR, 2005; RISSMAN et al., 1995), no processamento sensorial de estímulos sexuais ou comunicativos (MARUSKA; TRICAS, 2007; MUSKE, 1993, OKA, 1997) e na regulação dos neurônios de $\mathrm{GnRH1}$, uma vez que os neurônios de $\mathrm{GnRH} 1$ possuem receptores $\mathrm{GnRHRn2}$ (MILLAR et al., 2001). Contudo não existem evidencias farmacológicas, morfológicas e funcionais para dar suporte a estas funções para o $\mathrm{GnRH} 2$ em nenhum vertebrado.

O comportamento sexual de vertebrados é regulado pelo sistema endócrino e neuroendócrino, onde as fêmeas que estão em processo de ovulação liberam um hormônio esteróide pré-ovulatório (DULKA et al., 1987). Estimulado por este feromônio os machos começam a seguir as fêmeas exercendo o comportamento especifico da espécie (KEZUKA et al., 1989). Foi visto que o comportamento 
sexual em goldfish começa varias horas antes da ovulação nas fêmeas (KOBAYASHI; SORENSEN; STACEY, 2002).

Diante disso, a elevação da expressão do GnRH2 no encéfalo de machos de Astyanax altiparanae no momento em que houve o estímulo reprodutivo, pode estar associado à função deste peptídeo na modulação do comportamento reprodutivo, uma vez que neste momento ocorre a junção de machos e fêmeas e, provavelmente, o gatilho para o aumento da expressão do GnRH2 em machos neste período, seja estimulado pelo feromônio liberado na água pelas fêmeas que estão na fase aptas à reprodução. Corroborando com o dado obtido, foi visto que o GnRH atua como potencializador do comportamento sexual em goldfish (MUNAKATA; KOBAYASHI, 2010).

A expressão do $\mathrm{GnRH} 2$ no encéfalo de machos em resposta ao estímulo reprodutivo foi extremamente rápida, mostrando o pico de expressão entre um intervalo de 0 a 30 minutos. Da mesma forma, a rapidez na atividade dos neurônios de $\mathrm{GnRH}$ é visto também em medaka, onde a expressão de $\mathrm{GnRH}$ nos neurônios da parte ventral da área preóptica foi de aproximadamente em 10 minutos (KARIGO et al., 2012).

Quando foi analisada a expressão do mRNA de GnRH3 no encéfalo de machos e fêmeas de $A$. altiparanae foi visto que sua expressão é em média 100 vezes maior que a do mRNA de $\mathrm{GnRH} 2$, portanto podemos sugerir que o $\mathrm{GnRH} 2$ apresenta seu papel biológico em menores quantidades quando comparados com o $\mathrm{GnRH} 3$, podendo ser mais potente.

O encéfalo de fêmeas mostrou um aumento da expressão do mRNA de $\mathrm{GnRH} 3$ às 8 horas pós estímulo, enquanto em machos a expressão se manteve constante. O horário do dia correspondente à 8 horas pós-estímulo foi às 16:00 h, e esta hora corresponde ao pico de atividade elétrica dos neurônios de $\mathrm{GnRH} 1$ durante o dia, ou seja, aqueles neurônios localizados no hipotálamo/área preóptica, com função hipofisiotrópica (KARIGO et al., 2012).No entanto, quando avaliamos quantitativamente as classe celulares gonadais, vimos que a desova ocorreu às 20 horas pós-estímulo reprodutivo, ou seja às 4:00 h da manhã. Por 
outro lado, em machos são vistas constantemente grandes quantidades de espermatozoides na luz do túbulo.

Dessa forma, os dados obtidos no presente trabalho evidenciam o GnRH3 como a forma hipofisiotrópica em $A$. altiparanae, uma vez que as fêmeas apresentaram um período de desova marcante e, antecedendo este período, ocorreu um aumento na expressão do mRNA de GnRH3 no encéfalo, além desse pico coincidir com o período do dia característico da alta atividade dos neurônios de GnRH hipofisiotrópico. Já em machos, como a expressão do mRNA de GnRH3 se apresentou mais alta, porém de forma constante, a maturação do espermatozoide deveria estar ocorrendo constantemente, o que foi comprovado com a presença desses na luz do túbulo.

\subsection{Injeção dos GnRHs - efeito in vivo}

É bem estabelecido na literatura a função do $\mathrm{GnRH}$ hipotalâmico na regulação e síntese de gonadotropinas, as quais promovem a maturação gonadal, no entanto estudos a respeito do $\mathrm{GnRH}$ na literatura são escassos para espécies da ordem Characiformes e quase nulos para o Astyanax altiparanae.

$O$ efeito dos diferentes GnRHs em Astyanax altiparanae por meio da injeção dessas moléculas foi avaliado em diversos aspectos, mostrando-se a razão gonadossomática uma ferramenta não precisa e ineficaz para tal analise, onde diferenças entre esta razão não foram observadas, no entanto quando analisamos de forma mais refinada, realizando a contagem das classes celulares do ovário ao longo do período amostrado, comparando os grupos tratados com o GnRH com o grupo controle, observamos que houve às 16 horas pós-estímulo (horário do dia 8:00 h) a presença significativa de complexos pós-ovulatórios caracterizando a ocorrência de desova no grupo injetado com GnRH2.

Este dado vai de encontro com o observado no experimento de indução à reprodução por redução do nível da água, quando a desova ocorreu às 20 horas pós-estímulo (horário do dia 4:00 h), ou seja, no inicio da manhã. 
Dessa forma, é visto que o $\mathrm{GnRH} 2$ foi o peptídeo que se mostrou eficaz em induzir a desova em lambari do rabo amarelo. Corroborando este fato foi visto que - GnRH2 foi capaz de aumentar a expressão do mRNA de $\beta \mathrm{LH}$ em todos os períodos amostrados pós-injeção, quando comparados com o controle e basal, exceto às 24 horas pós-estímulo (horário do dia 16:00 h), onde os níveis de mRNA de $\beta$ LH retornaram aos níveis basais, já em relação aos níveis de mRNA de $\beta F S H$, estes mantiveram-se constantes por todo o período amostrado. O mesmo padrão na expressão das gonadotropinas foi observado para todos os tratamentos com os GnRHs, com um aumento mais acentuado da expressão de mRNA de $\beta \mathrm{LH}$ às 2 horas pós-estímulo, diferentemente do tratamento com $\circ \mathrm{GnRH} 2$, onde 0 aumento acentuado da expressão do mRNA de $\beta$ LH se mostrou em dois picos, às 2 horas e às 10 horas pós injeção.

Em goldfish o padrão de expressão das gonadotropinas após injeção com GnRH foi observado às 24 horas (KLAUSEN; CHANG; HABIBI, 2002), já em medaka expressão do mRNA de $\beta$ LH se deu às 16 horas pós tratamento (KARIGO et al., 2012) e em Clarias gariepinus o aumento dos níveis de mRNA de $\beta L H$ foi às $8 \mathrm{~h}$ após a injeção (REBERS et al., 2000), portanto nestas espécies o tempo de resposta ao tratamento do $\mathrm{GnRH}$ se mostrou diferente daquele visto em lambari. No entanto em fêmeas de Cyprinus carpio o padrão de expressão das gonadotropinas foi o mesmo observado no presente estudo, mas somente em fêmeas pós-vitelogênicas (YARON et al., 2003).

As diferenças citadas acima quanto à resposta à injeção de diferentes GnRHs provavelmente variam de acordo com a espécie, além da fase reprodutiva em que o animal se encontra e ainda do tipo de $\mathrm{GnRH}$ que foi usado no tratamento, uma vez que o decapeptídeo com a sequência intacta e natural de seus aminoácidos, como foi injetado em lambari, apresenta uma degradação rápida (ZOHAR et al., 1990), já os análogos de GnRH muitas vezes apresentam inserções de aminoácidos para protege-los de ação de peptidases, fazendo com que eles possam agir por mais tempo (PODHOREC; KOURIL, 2009). Diferentemente do intuito do presente trabalho, onde o interesse foi saber qual a 
ação do GnRH endógeno, a aplicação de $\mathrm{GnRH}$ análogo é utilizada para fins de obtenção de desova e consequente produção de alevinos.

Normalmente, em teleósteos assim como em alguns tetrápodes acredita-se que o FSH exerça sua função durante as fases iniciais da gametogênese, sendo um potente indutor da síntese de estrógenos pelo ovário (LEVAVI SIVAN et al., 2010; YARON et al., 2003), enquanto o LH regula as fases finais da gametogênese incluindo a maturação final do oócito e do espermatozoide, assim como a ovulação e espermiação, sendo importante na síntese de estrógenos, andrógenos e esteróide indutor da maturação (MIS), como principalmente o 17a,20ß-dihydroxy-4-pregnen-3-one (LEVAVI SIVAN et al., 2010; YARON et al., 2003).

O dado acima citado pode explicar o fato da injeção dos $\mathrm{GnRHs}$ terem estimulado a síntese somente do $\beta \mathrm{LH}$ e não do $\beta F S H$, uma vez que as fêmeas se encontravam nas fases finais de maturação, com ovários repletos de oócitos vitelogênicos, com o LH estimulando a síntese do MIS. No entanto, o aumento nos níveis desse esteróide ocorreu somente em fêmeas injetadas com o $\mathrm{GnRH} 2$ e às 10 horas pós-estímulo (horário do dia 2:00 h), indo de encontro com os dados encontrados na analise quantitativa das classes celulares gonadais, onde as somente as fêmeas injetadas com o GnRH2 mostraram ter desovado, sendo a desova às 16 horas pós-estímulo, ou seja, após o aumento do conteúdo do MIS circulante.

A evidência dos níveis de mRNA de $\beta \mathrm{LH}$ apresentarem dois picos mais acentuados de expressão após a administração do $\mathrm{GnRH} 2$ durante todo o período amostrado, diferentemente daqueles injetados com $\mathrm{GnRH} 3$ e $\mathrm{GnRH} 1$ onde houve um aumento acentuado às 2 horas pós-estímulo, faz supor que o LH pode ter sido capaz de induzir a síntese do MIS. Além disso, foi observado no item 6.2 que a expressão do mRNA de GnRH2 se mostrou 100 vezes menor que a expressão do mRNA GnRH3, sendo que provavelmente o GnRH2 exerça seu efeito biológico com menores quantidades que o $\mathrm{GnRH3}$, e, dessa forma, a concentração aplicada do $\mathrm{GnRH} 3$ pode não ter sido suficiente para desencadear toda a cascata hormonal que levaria o animal à desova. Além do mais, como mencionado no item 6.1, o 
decapeptídeo GnRH3 de $A$. altiparanae mostrou ter uma sequência diferente dos demais GnRH3 de teleósteos, e talvez este fato explique a falta de efeito observado para injeção do $\mathrm{GnRH3}$, o qual apresentava a sequência comum a todos os teleósteos.

Ainda pelo fato de somente o $\mathrm{GnRH} 2$ ter sido capaz de ativar toda a cascata hormonal do eixo reprodutivo pode ser explicado pela sua pré conformação em turn $\beta / I$ (MILLAR, 2003) o que faz deste ligante mais estável que os outros GnRHs, sendo menos susceptível a degradação de peptidases.

Já em relação ao $\mathrm{GnRH1}$, como citado anteriormente no item 6.1, acreditamos que este não esteja presente em $A$. altiparanae, devendo ser 0 GnRH3 a forma hipofisiotrópica nesta espécie.

Estudos demonstraram a promiscuidade dos receptores de $\mathrm{GnRH}$, sendo visto na maioria dos estudos com administração in vivo ou in vitro, o $\mathrm{GnRH} 2$ como o mais potente estimulador de gonadotropinas (LETHIMONIER et al., 2004; KAH et al., 2007), e o GnRH1 o menos eficiente na ligação com os receptores (SERVILI et al., 2010). No entanto, apesar de existirem controvérsias a respeito da presença do $\mathrm{GnRH} 2$ na hipófise em situações fisiológicas, já foi detectado $\mathrm{GnRH} 2$ na hipófise de zebrafish (STEVEN et al., 2003, XIA et al.,2014) assim como de goldfish (ROSEMBLUM; GOOS; PETER, 1994) e de Verasper moseri (AMANO et al., 2002), além do mais, é visto que em teleósteos houve a perda dos receptores de $\mathrm{GnRH} 1$, sendo todos os outros receptores encontrados em teleósteos responsivos ao GnRH2 (ROCH; BUSBY; SHERWOOD, 2014).

Dessa forma a questão intrigante é porque fisiologicamente manter um peptídeo menos efetivo durante a escala evolutiva, já que seu receptor não está presente? A explicação vista na literatura para tal fato é que comparado com o $\mathrm{GnRH} 2$, o $\mathrm{GnRH} 1$ ou então $\circ \mathrm{GnRH3}$ dependendo da espécie são liberados próximos a células gonadotrópicas da hipófise, as quais possuem os receptores GnRH tipo II (GONZALEZ MARTINEZ et al., 2004), e a quantidade liberada seria suficiente para ativar os receptores presentes na hipófise $(\mathrm{ROCH}$; BUSBY; SHERWOOD, 2014). 
Como considerações finais, em resumo, temos que os resultados obtidos no presente trabalho demonstraram alta conservação principalmente da sequência do cDNA do preproGnRH2 de $A$. altiparanae. Em relação à sequência predita de aminoácidos do preproGnRH3, foi constatada uma alteração do aminoácido presente na posição 8 do decapeptídeo $\mathrm{GnRH3}$, sendo a leucina encontrada no GnRH3 na maioria dos teleósteos substituída por metionina nesta mesma localização em Astyanax altiparanae, porém as possíveis consequências dessa alteração devem ser melhor investigadas.

Com relação à indução à reprodução por redução do nível da água, podese inferir, após as análises realizadas, que o método empregado foi satisfatório, uma vez que machos e fêmeas apresentaram uma redução do número de gametas maduros nas gônadas após o período amostrado. Além disso, observouse que em cativeiro o Astyanax altiparanae apresenta um desenvolvimento assincrônico com desova parcelada durante o período reprodutivo.

Ainda tratando-se dos animais submetidos à indução à reprodução, foi visto um aumento da expressão de mRNA de $\mathrm{GnRH} 2$ em machos e o aumento da expressão de mRNA de GnRH3 em fêmeas. Estes dados, juntamente com os resultados obtidos nas análises quantitativas das gônadas e com o processo de caracterização das sequências dos GnRHs, nos levam a propor que o GnRH2 provavelmente exerce uma função ligada ao comportamento reprodutivo e o GnRH3 possivelmente seja a forma hipofisiotrópica em Astyanax altiparanae.

E por fim, quando analisamos o efeitos dos GnRHs in vivo, somente o GnRH2 se mostrou capaz desencadear toda a cascata hormonal necessária levando o animal à desova.

\section{CONCLUSÃO}

Neste trabalho, concluiu-se que:

$\checkmark$ As sequências do cDNAs do preproGnRH2 e preproGnRH3 de $A$. altiparanae se mostraram altamente conservadas, principalmente a sequência do preproGnRH2. 
$\checkmark$ Houve uma alteração do aminoácido presente na posição 8 na predita sequência do decapeptídeo $\mathrm{GnRH}$.

$\checkmark$ A indução à reprodução por redução do nível da água foi satisfatório.

$\checkmark$ Em cativeiro o Astyanax altiparanae apresenta um desenvolvimento assincrônico com desova parcelada durante o período reprodutivo.

$\checkmark$ Em Astyanax altiparanae o GnRH2 provavelmente exerce uma função ligada ao comportamento reprodutivo.

$\checkmark \mathrm{O}$ GnRH3 possivelmente seja a forma hipofisiotrópica em Astyanax altiparanae.

$\checkmark$ Somente a injeção do GnRH2 mostrou-se capaz desencadear toda a cascata hormonal necessária levando o animal à desova. 


\section{REFERÊNCIAS*}

ABRAHAM E.; PALEVITCH, O.; GOTHILF, Y.; ZOHAR, Y. Targeted gonadotropin releasing hormone-3 neuron ablation in zebrafish: effects on neurogenesis neuronal migration and reproduction. Endocrinology, v. 151, p. 332-340, 2010.

AGOSTINHO, C. A.; MOLINARI, S. L.; AGOSTINHO, A. A.; VERANI, J. R. Ciclo reprodutivo e primeira maturação sexual de fêmeas do lambari, Astyanax bimaculatus (L.) (Osteichthyes - Characidae) do rio Ivaí, Estado do Paraná. Revista Brasileira de Biologia, v. 44, p. 31-36, 1984.

AGOSTINHO, A. A.; MIRANDA, L. E.; BINI, L. M.; GOMES, L. C.; THOMAZ, S. M.; SUZUKI, $\mathrm{H}$. I. Patterns of colonization in neotropical reservoirs, and prognosis on aging.. In: TUNDISI, J. G.; STRASKRABA, M. (Eds.). Theoretical Reservoir Ecology and its Applications. São Carlos: Backhuys Publishers, 1999, p. 227265.

AMANO, M.; OKO, Y.; YAMANOME, T.; OKUZAWA, K.; YAMAMORI, K. Three $\mathrm{GnRH}$ systems in the brain and pitiuitary of a Pleuronectiformes fish, the barfin flounder Varasper moseri. Cell and Tissue Research,. v. 309, p. 323-329, 2002. AN, K. W.; NELSON, E. R.; HABIBI, H. R.; CHOI, C. Y., Molecular characterization and expression of three GnRH forms mRNA during gonad sex-change process, and effect of GnRHa on GTH subunits mRNA in the protandrous black porgy (Acanthopagrus schlegell). General and Comparative Endocrinology, v. 159, p. 38-45, 2008.

ANDO, N.; MIURA, T.; NADER, M. R.; MIURA, C.; YAMAUCHI, K. A method for estimating the number of mitotic divisions in fish testes. Fisheries Sciences, v. 66, p. 299-303, 2000.

ANCTIL, M. Evidence for gonadotropin-releasing hormone-like peptides in a cnidarian nervous system. General and Comparative Endocrinology, v. 119, p. 317-328, 2000.

BABIN, P. J.; CARNEVALI, O.; LUBZENS, E.; SCHNEIDER, W. J. Molecular aspects of oocyte vitellogenesis in fish. In: Babin, P. J.; Cerdà, J.; Lubzens, E. (Eds.). The Fish Oocyte: From Basic Studies to Biotechnological Applications. Dordrecht: Springer, 2007, p. 39-76.

BAUER, M. P.; BRIDGHAM, J. T.; LANGENAU, D. M.; JOHNSON, A. L.; GOETZ, F. W. Conservation of steroidogenic acute regulatory (StAR) protein structure and

*De acordo com: ASSOCIAÇÃO BRASILEIRA DE NORMAS TECNICAS. NBR 6023: informação e documentação: referências: elaboração. Rio de Janeiro, 2002. 
expression in vertebrates. Molecular and Cellular Endocrinology, v. 168, p. 119-125, 2000.

BAYNES, S. M.; SCOTT, A. P. Seasonal variations in parameters of milt production and in plasma concentrations of sex steroids of male rainbow trout. General and Comparative Endocrinology, v.57, p.150-160, 1985.

BAYUNOVA, L.; BARANNIKOVA, I.; SEMENKOVA, T. Sturgeon stress reactions in aquaculture. Journal of Applied Ichthyology, v. 18, p. 397-404, 2002.

BEGOVAC, P. C.; WALLACE, R. A. Stages of oocyte development in the pipefish, Syngnathus scovelli. Journal of Morphology, v. 197, p. 353-369, 1988.

BERG, A. H.; MODIG, C.; OLSSON, P. E. 17beta-estradiol induced vitellogenesis is inhibited by cortisol at the post-transcriptional level in Arctic charr (Salvelinus alpinus). Reproductive Biology and Endocrinology, v. 2, p. 6, 2004.

BILLARD, R. Reproduction in rainbow trout: sex differentiation, dynamics of gamteogenesis, biology and preservation of gametes. Aquaculture, v. 100, p. 263-298, 1992.

BOBE, J.; LABBÉ, C. Egg and sperm quality in fish. General and Comparative Endocrinology, v. 165, p. 535-548, 2010.

BOCK, C. L.; PADOVANI, C. R. Considerações sobre a reprodução artificial e alevinagem de pacu (Piaractus mesopotamicus, Holmberg, 1887) em viveiros. Acta Scientiarum Biological Sciences, v. 2, p. 495-501, 2000.

BOGERD, J.; DIEPENBROEK, W. B.; HUND, E.; OOSTERHOUT, F. V.; TEVES, A. C.; LEURS, R.; BLOMENRÖHR, M. Two gonadotropin-releasing hormone receptors in the African catfish: no differences in ligand selectivity, but differences in tissue distribution. Endocrinology, v. 143, p. 4673-4682, 2002.

BORG, B. Androgens in teleost fishes. Comparative Biochemistry and Physiology Part C, v. 109, p. 219-245, 1994.

BORG, B.; ANTONOPOULOU, E.; MAYER, I.; ANDERSSON, E.; BERGLUND, I.; SWANSON P. Effects of gonadectomy and androgen treatments on pituitary and 
plasma levels of gonadotropins in mature male Atlantic salmon, Salmo salar, parrpositive feedback control of both gonadotropins. Biology of Reproduction, v. 58, p. 814-820, 1998.

BOSMA, P. T.; REBERS, F. E. M.; DIJK, W. V.; WILLEMS, P. H. G. M.; GOOS, H. J. TH.; SCHULZ, R. W. Inhibitory and stimulatory interactions between endogenous gonadotropin-releasing hormones in the African catfish (Clarias gariepinus). Biology of Reproduction, v. 62, p. 731-738, 2000.

BRAAT, A. K.; SPEKSNIJDER, J. E.; ZIVKOVIC, D. Germ line development in fishes. International Journal of Developmental Biology, v. 43, p. 745-760, 1999.

BRETON, B.; GOVOROUN, M.; MIKOLAJCZYK, T. GTH I and GTH II secretion profiles during the reproductive cycle in female rainbow trout: relationship with pituitary responsiveness to GnRH-A stimulation. General and Comparative Endocrinology, v. 111, p. 38-50, 1998.

BRONSON, F. H.; VOM SAAL, F. S. Control of the preovulatory release of luteinizing hormone by steroids in the mouse. Endocrinology, v. 104, p. 12471255, 1979.

BROOKS, S.; TYLER, C. R.; SUMPTER, J. P. Egg quality in fish: what makes a good egg? Reviews in Fish Biology and Fisheries, v. 7, p. 387-416, 1997.

BROWN PETERSON, N.; WYANSKI, D. M.; SABORIDO REY, F.; MACEWICZ B. J.; LOWERRE BARBIERI. S. K. A standardized terminology for describing reproductive development in fishes. Marine and Coastal Fisheries, v. 3, p. 52-70, 2011.

BURGUS, R.; BUTCHER, M.; AMOSS, M.; LING, N.; MONAHAN, M.; RIVIER, J.; FELLOS, R.; BLACKWELL, R.; VALE, W.; GUILLEMIN, R. Primary structure of the ovine hypothalamic luteinizing hormone releasing factor (LRF). Proceedings of the National Academy of Sciences, v. 69, p.278-282, 1972.

BURZAWA GERARD, E. Chemical data on pituitary gonadotropins and their implication to evolution. Canadian Journal of Fisheries and Aquatic Sciences, v. 39, p. $80-91,1982$. 
CALLARD, G. V. Endocrinology of Leydig cells in nonmammalian vertebrates. In: PAYNE, A. H.; HARDY, M. P.; RUSSELL, L. D. (Eds.). The Leydig Cell. Vienna, IL, USA: Cache River Press, 1996, p. 308-331.

CAMPOS, V. F.; COLLARES, T.; DESCHAMPS, J. C.; SEIXAS, F. K.; OKAMOTO, M. H.; SAMPAIO, L. A.; MARINS, L. F.; ROBALDO, R. B. Clonagem e avaliação da expressão gênica do sbGnRH em machos juvenis e adultos de linguado, Paralichthys orbignyanus. Arquivo Brasileiro de Medicina Veterinaria e Zootecnia, v. 63, n. 1, p. 239-246, 2011.

CÁNePA, M. M.; POZZI, A. G.; ASTOLA, A.; MAGGESE, M. C.; VISSIO, P. G. Effect of salmon melanin-concentrating hormone and mammalian gonadotrophin releasing hormone on somatolactin release in pituitary culture of Cichlasoma dimerus. Cell and Tissue Research, v. 333, p. 49-59, 2008.

CAROLSFELD, J.; RAMOS, S. M.; ORMANEZI, R.; GOMES, J. H.; BARBOSA, J. M.; HARVEY, B. Analysis of protocols for application of LHRH analog for induced final maturation and ovulation of female Pacu (Piaractus mesopotamicus Holmberg, 1887). Aquaculture, v. 74, p. 49-55,1988.

CASATTI, L.; LANGEANI, F.; CASTRO, R. M. C. Peixes de riacho do Parque Estadual Morro do Diabo, bacia do alto rio Paraná, SP. Biota Neotropical, v. 1, p. 1-15, 2001.

CASTRANOVA, D. A.; KING, W.; WOODS, L. C. The effects of stress on androgen production, spermiation response and sperm quality in high and low cortisol responsive domesticated male striped bass. Aquaculture, v. 246, p. 413-422, 2005.

CERDÀ, J.; REIDENBACH, S.; PRÄTZEL, S.; FRANKE, W. W. Cadherin-catenin complexes during zebrafish oogenesis: heterotypic junctions between oocytes and follicle cells. Biology of Reproduction, v. 61, p. 692-704, 1999.

CHANDROO, K. P.; DUNCAN, I. J. H.; MOCCIA, R. D.Can fish suffer? Perspectives on sentience, pain, fear and stress. Applied Animal Behaviour Science, v. 86, p. 225-250, 2004.

CHEN, A.; YAHALOM, D.; BEN AROYA, N.; KAGANOVSKY, E.; OKON, E.; $\mathrm{KOCH}, \mathrm{Y}$. A second isoform of gonadotropin-releasing hormone is present in the brain of human and rodents. FEBS Letter, v. 435, p. 199-203, 1998. 
CHEN, C. C.; FERNALD, R. D. Distributions of two gonadotropin-releasing hormone receptor types in a cichlid fish suggest functional specialization. Journal of Comparative Neurology, v. 495, p. 314-323, 2006.

CHEUNG, T. C.; HEARN, J. P. Molecular cloning and tissue expression of the gonadotropin-releasing hormone receptor in the tammar wallaby (Macropuseu genii). Reproduction, Fertility and Development, v.14, p. 157-164, 2002.

CLEARY, J. J.; PANKHURST, N. W.; BATTAGLEN, S.C. The effect of capture and handling stress on plasma steroid levels and gonadal condition in wild and farmed snapper Paragus auratus (Sparidae). Journal of the World Aquaculture Society, v. 31, p. 558-569, 2007.

CONSTEN, D.; LAMBERT, J. G.; KOMEN H.; GOOS, H. J. Corticosteroids affect the testicular androgen production in male common carp (Cyprinus carpio L.). Biology of Reproduction, v. 66, p. 106-111, 2002.

COWARD, K.; BROMAGE, N. Spawning frequency, egg size and ovarian histology in groups of Tilapia zillii maintained upon two distinct food ration sizes from firstfeeding to sexual maturity. Aquatic Living Resources, v. 12, p. 11-22, 1999.

DAVID, D.; DEGANI, G. Temperature Affects Brain and Pituitary Gene Expression Related to Reproduction and Growth in the Male Blue Gouramis, Trichogaster Trichopterus. Journal of Experimental Zoology, v. 214, p. 315-203, 2011.

DODD, J. M. The ovary. In: Pang, P. K. T.; Shcreibman, M. P. (Eds.). Vertebrate endocrinology: fundamentals and biomedical implications. San Diego, California: Academic Press, 1986, p. 351-397.

DUBOIS, E. A.; ZANDBERGEN, M. A.; PEUTE, J.; GOSS, H. J. Evolutionary development of three gonadotropin-releasing hormone $(\mathrm{GnRH})$ systems in vertebrates. Brain Research Bulletin, v. 57, p. 413-418, 2002.

DULKA, J. G.; STACEY, N. E.; SORENSEN, P. W.; VAN DER KRAAK, G. J. A sex steroid pheromone synchronizes male-female spawning readiness in goldfish. Nature, v. 325, p. 251-253, 1987. 
EISTHEN, H. L.; DELAY, R. J.; WIRSIG WIECHMANN, C. R.; DIONNE, V. E. Neuromodulatory effects of gonadotropin releasing hormone on olfactory receptor neurons. Neuroscience, v. 20, p. 3947-3955, 2000.

ESTEVES, K. E.; GALETTI JÚNIOR, P. M. Food partitioning among some characids of a small Brazilian flood plain lake from the Paraná river Basin. Environmental Biology of Fishes, v. 42, p. 375-389, 1995.

FERGUSON, S. S. Evolving concepts in G protein-coupled receptor endocytosis the role in receptor desensitization and signaling. Pharmacology Reviews, 53, 124, 2001.

FERNALD, R. D.; WHITE, R. B. Gonadotropin-releasing hormone genes: phylogeny, structure, and functions. Frontiers in Neuroendocrinology, v. 20, p. 224-240, 1999.

FORFAR, R.; LU, Z. L. Role of the transmembrane domain 4 / extracellular loop2 junction of the human gonadotropin-releasing hormone receptor in ligand binding and receptor conformational selection. Journal of Biological Chemistry, v. 286, p. 34617-34626, 2011.

GARCIA LOPEZ, A.; BOGERD, J.; GRANNEMAN, J. C. M.; DIJK, W. V.; TRANT, J. M.; TARANGER, G. L.; SCHULZ, R. W. Leydig Cells Express FollicleStimulating Hormone Receptors in African Catfish. Endocrinology, v. 150, n. 1, p. 357-365, 2009.

GARUTTI, V.; BRITSKI, H. A. Descrição de uma espécie nova de Astyanax (Teleostei: Characidae) da bacia do alto Rio Paraná e considerações gerais sobre as demais espécies do gênero na bacia. Comunicação do Museu de Ciências e Tecnologia PUCRS Série Zoologia, v. 13, p. 65-88, 2000.

GOETZ, F. W.; THEOFAN, G. In vitro stimulation of germinal vesicle breakdown and ovulation of yellow perch (Perca flavescens) oocytes. Effects of 17a-hydroxy20- dihydroprogesterone and prostaglandins. General and Comparative Endocrinology, v. 37, p. 273-285, 1979.

GOLAN, M.; BIRAN, J.; LEVAVI-SIVAN, B. A novel model for development, organization, and function of gonadotropes in fish pituitary. Frontiers in Endocrinology, v. 5, n. 182, p. 1-11, 2014. 
GOLDSTEIN, J. L.; BROWN, M. S. Regulation of the mevalonate pathway. Nature, v. 343, p. 425-430, 1990.

GOMES, C. C.; COSTA, F. G.; BORELLA, M. I. Distribution of GnRH in brain and pituitary gland of Astyanax altiparanae. Micron, v. 53, p. 36-38, 2013.

GOMEZ, J. M.; WEIL, C.; OLLITRAULT, M.; LE BAIL, P. Y.; BRETON, B.; LE GAC, F. Growth Hormone (GH) and Gonadotropin Subunit Gene Expression and Pituitary and Plasma Changes during Spermatogenesis and Oogenesis in Rainbow Trout (Oncorhynchus mykiss). General and Comparative Endocrinology, v. 113, p. 413-428, 1999.

GOMIERO, L. M.; BRAGA, F. M. S. O lambari Astyanax altiparanae (Characidae) pode ser um dispersor de sementes? Acta Scientiarum Biological Sciences, v. 25, n. 2, p. 353-360, 2003.

GONZALEZ MARTINEZ, D.; MADIGOU, T.; MANANOS, E.; CERDA REVERTER, J. M.; ZANUY, S.; KAH, O.; MUÑOZ CUETO, J. A. Cloning and expression of gonadotropin-releasing hormone receptor in the brain and pituitary of the European sea bass: an in situ hybridization study. Biology of Reproduction, v. 70, p. 13801391, 2004.

GOPINATH, A.; ANDREW TSENG, L.; WHITLOCK, K. E. Temporal and spatial expression of gonadotropin releasing hormone $(\mathrm{GnRH})$ in the brain of developing zebrafish (Danio rerio). Gene Expression Patterns, v. 4, p. 65-70, 2004.

GOPURAPPILLY, R.; OGAWA, S.; PARHAR, I. S. Functional significance of GnRH and kisspeptin, and their cognate receptors in teleost reproduction. Frontiers in Endocrinology, v. 4, p. 1-13, 2013.

GOUY, M.; GUINDON, S.; GASCUEL, O. SeaView Version 4: A Multiplatform Graphical User Interface for Sequence Alignment and Phylogenetic Tree Building. Molecular Biology and Evolution, v. 27, n. 2, p. 221-224, 2010.

GRIER, H. J. Cellular organization of the testis and spermatogenesis in fishes. American Zoology, v. 21, p. 345-357, 1981. 
GRIER, H. J. Comparative organization of Sertoli cells including the Sertoli cell barrier. In: RUSSELL, L. D.; GRISWOLD, M. D. (Eds.). The Sertoli cell. Clearwater: Cache River Press, 1993, p. 703-739.

GRIER, H. Ovarian germinal epithelium and folliculogenesis in the common snook, Centropomus undecimalis (Teleostei: Centropomidae). Journal of Morphology, v. 243, p. 265-281, 2000.

GRIER, H. J.; URIBE ARANZABAL, M. C.; PATIÑO, R. The ovary, folliculogenesis, and oogenesis in teleosts. In: Jamieson, B. G. M. (Ed.). Reproductive biology and phylogeny of fishes (agnathans and bony fishes). New Hampshire: Science Publishers, Enfield, 2009, v. 8A, p. 25-84.

GUILGUR, L. G.; MONCAUT, N. P.; CANARIO, A. V.; SOMOZA, G. M. Evolution of $\mathrm{GnRH}$ ligands and receptors in gnathostomata. Comparative Biochemistry and Physiology, Part A, v. 144, p. 272-283, 2006.

GUR, G.; BONFIL, D.; SAFARIAN, H.; NAOR, Z.; YARON, Z. GnRH signaling pathways regulate differentially the tilapia gonadotropin subunit genes. Molecular and Cellular Endocrinology, v. 189, p. 125-134, 2002.

GURAYA, S. S. The cell and molecular biology of fish oogenesis. Monographs in Developmental Biology, v. 18, p. 1-223, 1986.

HAIDER, S.; RAO, N. V. Induced spawning of maturing Indian catfish, Clarias batrachus (L.), using low doses of steroid hormones and salmon gonadotropin. Aquaculture Research, v. 25, p. 401-408, 1994.

HAPGOOD, J. P.; SADIE, H.; VANBILJON, W.; RONACHER, K. Regulation of expression of mammalian gonadotropin-releasing hormone receptor genes. Journal of Neuroendocrinology, v. 17, p. 619-638, 2005.

HASSIN, S.; ELIZUR, A.; ZOHAR, Y. Molecular cloning and sequence analysis of striped bass (Morone saxatilis) gonadotropins I and II subunits. Journal of Molecular Endocrinology, v. 15, p. 23-35, 1995.

HAWKINS, M. B.; THORNTON, J. W.; CREWS, D.; SKIPPER, J. K.; DOTTE, A.; THOMAS, P. Identification of a third distinct class of estrogen receptor and 
classification of estrogen receptors in teleosts. Proceedings of the National Academy of Sciences, v. 97, p. 10751-10756, 2000

HILDAHL, J.; TARANGER, G. L.; NORBERG, B.; HAUG, T. M.; WELTZIEN, F. A. Differential regulation of $\mathrm{GnRH}$ ligand and receptor genes in the brain and pituitary of Atlantic cod exposed to different photoperiod. General and Comparative Endocrinology, v. 180, p. 7-14, 2013.

HSIEH S. L.; CHUANG H. C.; NAN F. H.; RUAN Y. H.; KUO C. M. Molecular cloning and gene expression of the gonadotropin-releasing hormone receptor in the orange-spotted grouper, Epinephelus coioides. Comparative Biochemistry and Physiology, Part B, v. 147, p. 209-221, 2007.

HU, S. Y.; CHEN, M. H. C.; LIN Y. C.; GONG, H. Y.; YANG, T. H.; WU, J. L. Cloning and functional analysis of the proximal promoter region of the $\mathrm{GnRH}$ genes from the silver sea bream (Sparus aurata). Comparative Biovhemistry and Physiology Part B, v. 151, p. 373-380, 2008.

HUGGARD NELSON, D. L.; NATHWANI, P. S.; KERMOUNI, A.; HABIBI, H.R. Molecular characterization of $\mathrm{LH}-\beta$ and $\mathrm{FSH}-\beta$ subunits and their regulation by estrogen in the goldfish pituitary. Molecular and Cellular Endocrinology, v. 188, v. 171-193, 2002.

HUHTANIEMI, I. T.; THEMMEN, A. P. Mutations in human gonadotropin and gonadotropin receptor genes. Endocrine, v. 26, p. 207-217, 2005.

ILLING, N.; TROSKIE, B. E.; NAHOR NIAK, C. S.; HAPGOOD, J. P.; PETER, R. E.; MILLAR, R. P. Two gonadotropin-releasing hormone receptor subtypes with distinct ligand selectivity and differential distribution in brain and pituitary in the goldfish (Carassius auratus). Proceedings of the National Academy of Sciences, v. 96, p. 2526-2531, 1999.

JAMIESON, B. G. M. Fish Evolution and Systematics: Evidence from Spermatozoa. Cambridge: Cambridge University Press, 1991.

JODO, A.; ANDO, H.; URANO, A. Five diferent types of putative GnRH receptor gene are expressed in the brain of masu salmon (Oncorhynchus masou). Zoological Science, v. 20, p. 1117-1125, 2003. 
KAH, O.; LETHIMONIER, C.; SOMOZA, G.; GUILGUR, L. G.; VAILLANT, C.; LAREYRE, J. J. GnRH and GnRH receptors in metazoa: A historical, comparative, and evolutive perspective. General and Comparative Endocrinology, v. 153, p. 346-364, 2007.

KANDA, S.; OKUBO, K.; OKA, Y. Differential regulation of the luteinizing hormone genes in teleosts and tetrapods due to their distinct genomic environments Insights into gonadotropin beta subunit evolution. General and Comparative Endocrinology, v. 173, p. 253-258, 2011.

KARIGO, T.; KANDA, S.; TAKAHASHI, A.; ABE, H.; OKUBO, K.; OKA, Y. Time-ofDay-Dependent Changes in GnRH1 Neuronal Activities and Gonadotropin mRNA Expression in a Daily Spawning Fish, Medaka. Endocrinology, v. 153, n. 7, p. 3394-3404, 2012.

KARSCH, F. J.; BATTAGLIA, D. F. Mechanism for endotoxin-induced disruption of ovarian cyclicity: observations in sheep. Reproduction Supplement, v. 59, p. 101113, 2002.

KASTEN, T. L.; WHITE, S. A.; NORTON, T. T.; BOND, C. T.; ADELMAN, J. P.; FERNALD, R. D. Characterization of Two New preproGnRH mRNAs in the Tree Shrew: First Direct Evidence for Mesencephalic GnRH Gene Expression in a Placental Mammal. General and Comparative Endocrinology, v. 104, p. 7-19, 1996.

KATO, Y.; GEN, K.; MARUYAMA, O.; TOMIZAWA, K.; KATO, T. Molecular cloning of cDNAs encoding two gonadotropin $\beta$ subunits $(G T H-I \beta$ and II $\beta$ ) from the masu salmon, Oncorhynchus masou: rapid divergence of the GTH-I $\beta$ gene. Journal of Molecular Endocrinology, v. 11, p. 275-282, 1993.

KAVALCO, K. F.; PAZZA, R.; BRANDÃO, K. D. O.; GARCIA, C.; ALMEIDATOLEDO, L. F. Comparative Cytogenetics and Molecular Phylogeography in the Group Astyanax altiparanae - Astyanax aff. Bimaculatus (Teleostei, Characidae) Cytogenetic Genome Research, v. 134, p. 108-119, 2011.

KAVANAUGH, S. I.; NOZAKI, M.; SOWER, S. A. Origins of gonadotropin-releasing hormone $(\mathrm{GnRH})$ in vertebrates: identification of a novel $\mathrm{GnRH}$ in a basal vertebrate, the sea lamprey. Endocrinology, v. 149, p. 3860-3869, 2008. 
KAZETO, Y.; IJIRI, S.; TODO, T.; ADACHI, S.; YAMAUCHI, K. Molecular Cloning and Characterization of Japanese Eel Ovarian P450c17 (CYP17) cDNA. General and Comparative Endocrinology, v. 118, p. 123-133, 2000.

KAZETO, Y.; KOHARA, M.; MIURA, T.; MIURA, C.; YAMAGUCHI, S.; TRANT, J. M.; ADACHI, S.; YAMAUCHI, K. Japanese eel follicle-stimulating hormone (Fsh) and luteinizing hormone (Lh): production of biologically active recombinant Fsh and Lh by Drosophila S2 cells and their differential actions on the reproductive biology. Biology of Reproduction, v. 79, p. 938-946, 2008.

KAWAI, T.; OKA Y.; EISTHEN, H. The role of the terminal nerve and GnRH in olfactory system neuromodulation. Zoological Science, v. 26, p. 669-680, 2009.

KAWAUCHI, H.; SUZUKI, K.; ITOH, H.; SWANSON, P.; NAITO, N.; NAGAHAMA, Y.; NOZAKI, M.; NAKAI, Y.; ITOH, S. The duality of fish gonadotropins. Fish Physiology and Biochemistry, v. 7, p. 29-38, 1989.

KERDELHUÉ, B.; BROWN, S.; LENOIR, V.; QUEENAN JUNIOR, J. T.; JONES, G. S.; SCHOLLER, R.; JONES JUNIOR, H. W. Timing of initiation of the preovulatory luteinizing hormone surge and its relationship with the circadian cortisol rhythm in the human. Neuroendocrinology, v. 75, p. 158-163, 2002.

KEZUKA, H.; KOBAYASHI, M.; AIDA, K.; HANYU. I. Effects of photoperiod and pinealectomy on the gonadotropin secretion and ovulation in goldfish Carassius auratus. Nippon Suisan Gakkaishi, v. 55, p. 2099-2103, 1989.

KHAKOO, Z.; BHATIA, A.; GEDAMU, L.; HABIBI, H. R. Functional specificity for salmon gonadotropin-releasing hormone $(\mathrm{GnRH})$ and chicken $\mathrm{GnRH}-\mathrm{Il}$ coupled to the gonadotropin release and subunit messenger ribonucleic acid level in the goldfish pituitary. Endocrinology, v. 134, p. 838-847, 1994.

KIM, N. N.; SHIN, H. S.; HABIBI, H. R.; LEE, J.; CHOI, C. Y. Expression profiles of three types of $\mathrm{GnRH}$ during sex-change in the protandrous cinnamon clownfish, Amphiprion melanopus: Effects of exogenous GnRHs. Comparative Biochemistry and Physiology, v. 162, p. 124-133, 2011.

KING, J. A.; DUFOUR, S.; FONTAINE, Y. A.; MILLAR, R. P. Chromatographic and immunological evidence for mammalian $\mathrm{GnRH}$ and chicken $\mathrm{GnRH}-\mathrm{Il}$ in eel (Anguilla anguilla) brain and pituitary. Peptides, v. 11, p. 507-514, 1990. 
KING, J. A.; MILLAR, R. P. Gonadotropin-releasing hormones. In: Vertebrate Endocrinology: Fundamental and Biomedical Implications. New York: Academic Press, 1991.

KING, J. A.; MILLAR, R. P. Evolution of gonadotropin releasing hormones. Trends Endocrinology and Metabolism, v. 3, p. 339-346, 1992.

KING, J. A.; MILLAR, R. P. Coordinated evolution of GnRHs and their receptors. In: PARHAR, I. S.; SAKUMA, Y. (Eds). GnRH neurons: Gene to behavior. Tokyo: Brain Shuppan, 1998, p. 51-77.

KING, V.W.; THOMAS, P.; HARRELL, R.M.; HODSON, R.G.; SULLIVAN, C.V. Plasma levels of gonadal steroids during final oocyte maturation of striped bass, Morone saxatilis. General and Comparative Endocrinology, v. 95, p. 178-191, 1994.

KING, V.W.; THOMAS, P.; SULLIVAN, C.V. Hormonal regulation of final maturation of striped bass oocytes in vitro. General and Comparative Endocrinology, v. 96, p. 223-233, 1994.

KING, V.W.; BERLINSKY, D.L.; SULLIVAN, C.V. Involvement of gonadal steroids in final oocyte maturation of white perch (Morone americana) and white bass (M. chrysops): in vivo and in vitro studies. Fish Physiology and Biochemistry, v. 14, p. 489-500, 1995.

KLAUSEN, C.; CHANG, J. P.; HABIBI, H. R. The effect of gonadotropin-releasing hormone on growth hormone and gonadotropin subunit gene expression in the pituitary of goldfish, Carassius auratus. Comparative Biochemistry and Physiology Part B, v. 129, p. 511-516, 2001.

KLAUSEN, C.; CHANG, J. P.; HABIBI, H. R. Time and dose-related effects of expression in the goldfish pituitary. Canadian Journal Physiology and Pharmacology Reviews, v. 80, p. 915-924, 2002.

KOBAYASHI, M.; SORENSEN, P. W.; STACEY, N. E. Hormonal and pheromonal control of spawning behavior in goldfish. Fish Physiology and Biochemistry, v. 26, p. 71-84, 2002. 
KOULISH, S.; KRAMER, C. R.; GRIER, H. J. Organization of the male gonad in a protogynous fish, Thalassoma bifasciatum (Teleostei: Labridae). Journal of Morphology, v. 254, p. 292-311, 2002.

KRYSKO, D. V.; DIEZ-FRAILE, A.; CRIEL, G.; SVISTUNOV, A. A.; VANDENABEELE, P.; D'HERDE, K. Life and death of female gametes during oogenesis and folliculogenesis. Apoptosis, v. 13, p. 1065-1087, 2008.

KUO, M. W.; LOU, S. W.; POSTLETHWAIT, J.; CHUNG, B. C. Chromosomal organization, evolutionary relationship, and expression of zebrafish $\mathrm{GnRH}$ family members. Journal of Biomedical Science, v.12, p. 629-639, 2005.

KUSAKABE, M.; NAKAMURA, I.; EVANS, J.; SWANSON, P.; YOUNG, G. Changes in mRNAs encoding steroidogenic acute regulatory protein, steroidogenic enzymes and receptors for gonadotropins during spermatogenesis in rainbow trout testes. Journal of Endocrinology, v. 189, p. 541-554, 2006.

LANGE, I. G.; HARTEL, A.; MEYER, H. H. D. Evolution of oestrogen functions in vertebrates. Journal of Steroid Biochemistry and Molecular Biology, v. 83, p. 219-226. 2003.

LE MENN, F.; CERDÀ, J.; BABIN, P. J. Ultrastructural aspects of the ontogeny and differentiation of ray-finned fish ovarian follicles. In: Babin, P. J. (Ed.). The Fish Oocyte: From Basic Studies to Biotechnological Application. The Netherlands: Springer, 2007, p. 1-37.

LEAL, M. C.; CARDOSO, E. R.; NÓBREGA, R. H.; BATLOUNI, S. R.; BOGERD, J.; FRANÇA, L. R.; SCHULZ, R. W. Histological and stereological evaluation of zebrafish (Danio rerio) spermatogenesis with an emphasis on spermatogonial generations. Biology of Reproduction, v. 81, n. 1, p. 177-87, 2009.

LEE, V. H. Y.; LEE, L. T. O.; CHOW, B. K. C. Gonadotropin-releasing hormone: regulation of the $\mathrm{GnRH}$ gene. FEBS Journal, v. 275, p. 5458-5478, 2008.

LESCHEID, D. W.; POWELL, D. F. F.; FISHER, W. H.; PARK, M.; CRAIG, A.; BUKOVSKAYA, O.; BARANNIKOVA, I. A.; SHERWOOD, N. M. Mammalian gonadotropin-releasing hormone $(\mathrm{GnRH})$ identified by primary structure in Russian sturgeon, Acipenser gueldenstaedti. Regulatory Peptides, v. 55, p. 299-309, 1995. 
LESCHEID, D. W.; ROSEN, G. J.; BRIDGE, A. E. A.; JONES, R. E.; WARBY, C. M.; SHERWOOD, N. M. Immunoreactive Gonadotropin-Releasing Hormone $(\mathrm{GnRH})$ Is Detected Only in the Form of Chicken $\mathrm{GnRH}$-II within the Brain of the Green Anole, Anolis arolinensis. General and Comparative Endocrinology, v. 108, p. 247-257, 1997.

LETHIMONIER, C.; MADIGOU, T.; MUÑOZ-CUETO, J. A.; LAREYRE, J. J.; KAH, O. Evolutionay aspects of $\mathrm{GnRHs}, \mathrm{GnRH}$ neuronal systems and $\mathrm{GnRH}$ receptor in teleost fish. General and Comparative Endocrinology, v. 135, p. 1-16, 2004.

LEVAVI SIVAN, B.; SAFARIAN, H.; ROSENFELD, H.; ELIZUR, A.; AVITAN, A. Regulation of gonadotropin-releasing hormone $(\mathrm{GnRH})$ receptor gene expression in tilapia: effect of $\mathrm{GnRH}$ and dopamine. Biology of Reproduction, v. 70, p. 1545-1551, 2004.

LEVAVI SIVAN, B.; AVITAN, A. Sequence analysis, endocrine regulation, and signal transduction of $\mathrm{GnRH}$ receptors in teleost fish. General and Comparative Endocrinology, v. 142, p. 67-73, 2005.

LEVAVI SIVAN, B.; BOGERD, J.; MANANOS, E. L.; GOMEZ, A.; LAREYRE, J. J. Perspectives on fish gonadotropins and their receptors. General and Comparative Endocrinology, v. 165, p. 412-37, 2010.

LIZAMA, M. A. P.; AMBROSIO, A. M. Condition factor in nine species of fish of the Characidae family in the Upper Paraná River floodplain, Brazil. Brazilian Journal of Biology, v. 62, p. 113-124, 2002.

LO, A.; CHANG, J. P. In Vitro Application of Testosterone Potentiates Gonadotropin-Releasing Hormone-Stimulated Gonadotropin-II Secretion from Cultured Goldfish Pituitary Cells. General and Comparative Endocrinology, v. 111 , p. 334-346, 1998.

LUBZENS, E.; YOUNG, G.; BOBE, J.; CERDÀ, J. Oogenesis in teleosts: How fish eggs are formed. General and Comparative Endocrinology, v. 165, p. 367-389, 2010.

LYMAN GINGERICH, J.; PELEGRI, F. Maternal factors in fish oogenesis and embryonic development. In: Babin, P. J.; Cerdà, J.; Lubzens, L. (Eds.). The Fish Oocyte From Basic Studies to Biotechnological Applications. The Netherlands: Springer, 2007, p. 141-174. 
MADIGOU, T.; MANANOS SANCHEZ, E.; HULSHOF, S.; ANGLADE, I.; ZANUY, $\mathrm{S}$.; $\mathrm{KAH}, \mathrm{O}$. Cloning, tissue distribution, and central expression of the gonadotropinreleasing hormone receptor in the rainbow trout (Oncorhynchus mykiss). Biology of Reproduction, v. 63, p. 1857-1866, 2000.

MANEY, D. L.; RICHARDSON, R. D.; WINGFIELD, J. C. Central administration of chicken gonadotropin-releasing hormone II enhances courtship behavior in a female sparrow. Hormone and Behavior, v. 32, p. 11-18, 1997.

MARSHALL, C. T.; YARAGINA, N.; LAMBERT, Y.; KJESBU, O. Total lipid energy as a proxy for total egg production by fish stocks. Nature, v. 402, p. 288-290, 1999.

MARTYNIUK, C. J.; BISSEGGER, S.; LANGLOIS, V. S. Current perspectives on the androgen 5 alpha-dihydrotestosterone (DHT) and 5 alpha-reductases in teleost fishes and amphibians. General and Comparative Endocrinology, v. 194, p. 264-274, 2013.

MARUSKA, K. P.; TRICAS, T. C. gonadotropin releasing hormone and receptor distributions in the visual processing regions of four coral reef fishes. Brain Behavior and Evolution, v. 70, p. 40-56, 2007.

MATSUO, H.; BABA, Y.; NAIR, R. M.; ARIMURA, A.; SCHALLY, A. V. Structure of the porcine $\mathrm{LH}$ - and $\mathrm{FSH}$-releasing hormone. I. The proposed amino acid sequence. Biochemistry Biophysical Research Communication, v. 43, p. 1334-1339, 1971.

MATTA, S. L.; VILELA, D. A.; GODINHO, H. P.; FRANÇA, L. R. The goitrogen 6-npropyl-2-thiouracil (PTU) given during testis development increases Sertoli and germ cell numbers per cyst in fish: the tilapia (Oreochromis niloticus) model. Endocrinology, v. 143, p. 970-978, 2002.

MATTEI, X. Peculiarities in the organization of testis of Ophidion sp. (Pisces: Teleostei). Evidence for two types of spermatogenesis in teleost fish. Journal of Fish Biology, v. 43, p. 931-937, 1993.

MCARDLE, C. A.; GOROSPE, W. C.; HUCKLE, W. R.; CONN, P. M. Homologous down-regulation of gonadotropin-releasing hormone receptor and desensitization of gonadotropes: lack of dependence on protein kinase C. Molecular Endocrinology, v. 1, p. 420-429, 1987. 
MCARDLE, C. A.; FORREST OWEN, W.; WILLARS, G.; DAVIDSON, J.; POCH, A.; KRATZMEIER, M. Densensitization of gonadotropin-releasing hormone action in the gonadotropin-derived aT3-1 cells line. Endocrinology, v. 136, p. 48644871, 1995.

MCARDLE, C. A.; DAVIDSON, J. S.; WILLARS, G. B.; The tail of the gonadotrophinreleasing hormone receptor: desensitization at, and distal to, $G$ protein-coupled receptors. Molecular and Cellular Endocrinology, v. 151, p. 129-136, 1999.

MCARDLE, C. A.; FRANKLIN, J.; GREEN, L.; HISLOP, J. N. Signalling, cycling and desensitisation of gonadotropin-releasing hormone receptors. Journal of Endocrinology, v. 173, p. 1-11, 2002.

MCGAUGH, S. E.; GROSS, J. B.; AKEN, B.; BLIN, M.; BOROWSKY, R.; CHALOPIN, D.; HINAUX, H.; JEFFERY, H. R.; KEENE, A.; MA, L.; MINX, P.; MURPHY, D.; O'QUIN, K. E.; RE'TAUX, S.; ROHNER, N.; SEARLE, S. M. J.; STAHL, B. A.; TABIN, C.; VOLFF, J.; YOSHIZAWA, M.; WARREN, W. C. The cavefish genome reveals candidate genes for eye loss. Nature Communications, v. 5, p. 1-10, 2014.

MELAMED, P.; ROSENFELD, H.; ELIZUR, A.; YARON, Z. Endocrine regulation of gonadotropin and growth hormone gene transcription in fish. Comparative Biochemistry and Physiology Part C: Pharmacology, Toxicology and Endocrinology, v. 119, p. 325-338, 1998.

MENUET, A.; PELLEGRINI, E.; ANGLADE, I.; BLAISE, O.; LAUDET, V.; KAH, O.; PAKDEL, F. Molecular characterization of three estrogen receptor forms in zebrafish: binding characteristics, transactivation properties, and tissue distributions. Biology of Reproduction, v. 66, p. 1881-1892, 2002.

MILLA, S.; WANG, S.; MANDIKI, S. N. M.; KESTEMONT, P. Corticosteroids: friends or foes of teleost fish reproduction. Comparative Biochemistry and Physiology Part A, v. 153, p. 242-251, 2009.

MILLAR, R.; LOWE, S.; CONKLIN, D.; PAWSON, A.; MAUDSLEY, S.; TROSKIE, B.; OTT, T.; MILLAR, M.; LINCOLN, G.; SELLAR, R.; FAURHOLM, B.; SCOBIE, G.; KUESTNER, R.; TERASAWA, E.; KATZ, A. A novel mammalian receptor for the evolutionarily conserved type II GnRH. Proceedings of the National Academy of Sciences, v. 98, p. 9636-9641, 2001. 
MILLAR, R.P. GnRH II and type II GnRH receptors. Trends in Endocrinology and Metabolism, v. 14, n. 1, p. 35-43, 2003.

MILLAR, R. P.; LU, Z. L.; PAWSON, A. J.; FLANAGAN, C. A.; MORGAN, K.; MAUDSLEY, S. R. Gonadotropin-releasing hormone receptors. Endocrinology Reviews, v. 25, p. 235-275, 2004.

MILLAR, R.P. GnRHs and GnRH receptors. Animal reproduction Science, v. 88, p. 5-28, 2005.

MILLER, K. E.; KRIEBEL, R. M. Peptidergic innervation of caudal neurosecretory neurons. General and Comparative Endocrinology, v. 64, p. 396-400, 1986.

MILTON, D. A.; BLABER, S. J. M.; RAWLINSON, N. J. F. Reproductive biology and egg production of three species of Clupeidae from Kiribati, tropical central Pacific. Fisheries Bulletin, v. 92, p. 102-121, 1994.

MIRANDA, A. C.; BAZZOLI, N.; RIZZO, E.; SATO, Y. Ovarian follicular atresia in two teleost species: a histological and ultrastructural study. Tissue and Cell, v. 31, p. 480-488, 1999.

MITSUO, N.; SELVARAJ, S.; KITANO, H.; SHIRAISHI, T.; YAMAGUCHI, A.; SHIMIZU, A.; MATSUYAMA, M. Immunoreactivity of Gonadotrophs (FSH and LH Cells) and Gonadotropin Subunit Gene Expression in the Male Chub Mackerel Scomber japonicus Pituitary during the Reproductive Cycle. Zoological Science, v. 29, p. 623-629, 2012.

MIURA, T.; YAMAUCHI, K.; TAKAHASHI, H.; NAGAHAMA, Y. Involvement of steroid hormones in gonadotropin-induced testicular maturation in male eel (Anguilla japonica). Biomedical Research, v. 12, p. 241-248, 1991.

MIURA, T.; YAMAUCHI, K.; TAKAHASHI, H.; NAGAHAMA, Y. The role of hormones in the acquisition of sperm motility in salmonid fish. Journal of Experimental Biology, v. 261, p. 359-363, 1992.

MIURA, T.; MIURA, C.; OHTA,T.; NADER, M. R.; TODO, T.; YAMAUCHI, K. Estradiol- 17 beta stimulates the renewal of spermatogonial stem cells in males. Biochemistry and Biophysical Research Communities, v. 264, p. 230-234, 1999. 
MIURA, T.; MIURA, C. I. Molecular control mechanisms of fish spermatogenesis. Fish Physiology and Biochemistry, v. 28, p. 181-186, 2003.

MONCAUT, N.; SOMOZA, G.; POWER, D. M.; CANÁRIO, A. V. M. Five gonadotrophin-releasing hormone receptors in a teleost fish: isolation, tissue distribution and phylogenetic relationships. Journal of Molecular Endocrinology, v. 34, p. 767-779, 2005.

MONTANER, A. D.; PARK, M.K.; FISCHER, W.; CRAIG, A.G.; CHANG, J.P.; SOMOZA, G.M.; RIVIER, J.E.; SHERWOOD, N.M. Primary structure of a novel gonadotropin-releasing hormone $(\mathrm{GnRH})$ variant in the brain of pejerrey (Odontesthes bonariensis). Endocrinology, v. 142, p. 1453-1460, 2001.

MOSCONI, G.; CARDINALETTI, G.; CAROTTI, M.; PALERMO, F.; SOVERCHIA, L.; POLZONETTI MAGNI, A. M. Neuroendocrine mechanisms regulating stress response in cultured teleost species. In: REINECKE, M.; ZACCONE, G.; KAPOOR, B. G. (Eds.). Fish Endocrinology, New Hampshire: Science Publishers Enfield. 2006, v. 2, p. 693-720.

MUNAKATA, A.; KOBAYASHI, M. Endocrine control of sexual behavior in telost fish. General and Comparative Endocrinology, v. 165, n.3, p. 456-468, 2010.

MUSKE L.E. Evolution of gonadotropin releasing hormone $(\mathrm{GnRH})$ neuronal systems. Brain Behavior and Evolution, v. 42, p. 215-230, 1993.

MYLONAS, C. C.; ZOHAR, Y. Endocrine regulation and artificial induction of oocyte maturation and spermiation in basses of the genus Morone. Aquaculture, v. 202, p. 205-220, 2001.

MYLONAS, C. C.; ZOHAR, Y. Promoting oocyte maturation, ovulation and spawning in farmed fish. In: BABIN, P. J.; CERDÀ, J.; LUBZENS, E. (Eds.). The fish oocyte: From basic studies to biotechnological applications. Netherlands: Springer, 2007. p. 437-474.

MYLONAS, C. C.; FOSTIER, A.; ZANUY, S. Broodstock management and hormonal manipulations of fish reproduction. General and Comparative Endocrinology, v. 165, p. 516-534, 2010. 
MORGAN, K.; SELLAR, R.; PAWSON, A. J.; LU, Z. L.; MILLAR, R. P. Bovine and ovine gonadotropin-releasing hormone $(\mathrm{GnRH})$-II ligand precursors and type II $\mathrm{GnRH}$ receptor genes are functionally inactivated. Endocrinology, v. 147, p. 5041-5051, 2006.

MURAKAMI, S.; KIKUYAMA, S.; ARAI, Y. The origin of the luteinizing hormonereleasing hormone (LHRH) neurons in newts (Cynops pyrrhogaster): The effect of olfactory placode ablation. Cell and Tissue Research, v. 269, p. 21-27, 1992.

NAGAHAMA, Y. Endocrine regulation of gametogenesis in fish. International Journal of Developmental Biology, v.38, p. 217-229, 1994.

NAGAHAMA, Y. 17 $\alpha$, 20ß-dihydroxy-4-pregnen-3-one, a maturating inducing hormone in fish oocytes: mechanisms of synthesis and action. Steroids, v. 62, p. 190-196, 1997.

NAGAHAMA ,Y.; YAMASHITA, M. Regulation of oocyte maturation in fish. Development Growth and Differentiation, v. 50, p. 195-219, 2008.

NEILL, J. D.; DUCK, L.W.; SELLERS, J. C.; MUSGROVE, L.C. A gonadotropinreleasing hormone $(\mathrm{GnRH})$ receptor specific for $\mathrm{GnRH}$ II in primates. Biochemistry Biophysical Research Communication, v.282, p. 1012-1018, 2001.

NELSON, J. S. Fishes of the world. 4 ed. New York: John Wiley and Sons, 2006, p. 601.

NGAMVONGCHON, S.; LOVEJOY, D. A; FISCHER, W. H.; CRAIG, A. G., NAHORNIAK, C. S.; PETER, R. E.; RIVIER, J. E.; SHERWOOD, N. M. Primary structures of two forms of gonadotropin releasing hormone, one distinct and one conserved, from catfish brain. Molecular and Cellular Neuroscience, v. 3, p. 1722, 1992.

NÓBREGA, R. H.; BATLOUNI, S. R.; FRANÇA, L. R. An overview of functional and stereological evaluation of spermatogenesis and germ cell transplantation in fish. Fish Physiology and Biochemistry, v. 35, p. 197-206, 2009.

NOMURA, H. Fecundidade, maturação sexual e índice gônado-somático de lambari do gênero Astyanax Baird \& Girard, 1854 (Osteichthyes, Characidae), 
relacionados com fatores ambientais. Revista Brasileira de Biologia, v. 35, p. 775-798, 1975.

OAKLEY, A. E.; BREEN, K. M.; CLARKE, I. J.; KARSCH, F. J.; WAGENMAKER, E. R.; TILBROOK, A. J. Cortisol Reduces Gonadotropin-Releasing Hormone Pulse Frequency in Follicular Phase Ewes: Influence of Ovarian Steroids. Endocrinology, v. 150, n. 1, p. 341-349, 2009.

OHTA, K.; MATSUYAMA, M. Steroidogenic pathways to 17,20b-dihydroxy-4pregnen-3-one and 17,20b,21-trihydroxy-4-pregnen-3-one in the ovarian follicles of the bambooleaf wrasse, Pseudolabrus sieboldin. Fisheries Science, v. 68, p. 4150, 2002.

OHTA, T.; MIYAKE, H.; MIURA, C.; KAMEI, H.; AIDA, K.; MIURA, T. Folliclestimulating hormone induces spermatogenesis mediated by androgen production in Japanese eel, Anguilla japonica. Biology of Reproduction, v. 77, p. 970-977, 2007.

OKA Y. GnRH neuronal system of fish brain as a model system for the study of peptidergic neuromoldulation. In: PAHAR I.S.; SAKUMA Y. (Eds). GnRH Neurons: Gene to behavior. Tokyo: Brain Shuppan, 1997, p. 245-276.

OKUBO, K.; ISHII, S.; ISHIDA, J.; MITANI, H.; NARUSE, K.; KONDO, M.; SHIMA, A.; TANAKA, M.; ASAKAWA, S.; SHIMIZU, N.; AIDA, K. A novel third gonadotropin-releasing hormone receptor in the medaka Oryzias latipes: evolutionary and functional implications. Gene, v. 314, p. 121-131, 2003.

OKUBO, K.; NAGAHAMA, Y. Structural and functional evolution of gonadotropinreleasing hormone in vertebrates. Acta Physiology, v.193, p. 3-15, 2008.

O’NEILL, D. F.; POWELL, J. F. F.; STANDEN, E. M.; YOUSON, J. H.; WARBY, C. M.; SHERWOOD, N. M. Gonadotropin-releasing hormone $(\mathrm{GnRH})$ in ancient teleosts, the bonytongue fishes: putative origin of salmon $\mathrm{GnRH}$. General and Comparative Endocrinology, v. 112, p. 415-425, 1998.

ONUMA, T.; ANDO, H.; KOIDE, N.; OKADA, H.; URANO, A. Effects of salmon $\mathrm{GnRH}$ and sex steroid hormones on expression of genes encoding growth hormone/prolactin/ somatolactin family hormones and a pituitary-specific transcription factor in masu salmon pituitary cells in vitro. General and Comparative Endocrinology, v. 143, p. 129-141, 2005. 
OZAKI, Y.; HIGUCHI, M.; MIURA, C.; YAMAGUCHI, S.; TOZAWA, Y.; MIURA, T. Roles of 11ßhydroxysteroid dehydrogenase in fish spermatogenesis. Endocrinology, v. 147, p. 5139-5146, 2006.

PANKHURST, N. W.; VAN DER KRAAK, G. Evidence that acute stress inhibits ovarian steroidogenesis in rainbow trout in vivo, through the action of cortisol. General and Comparative Endocrinology, v. 117, p. 225-237, 2000.

PARENTI, L. R.; GRIER, H. J. Evolution and phylogeny of gonad morphology in bony fishes. Integrative and Comparative Biology, v. 44, p. 333-348, 2004.

PARHAR, I. S.; SOGA, T.; ISHIKAWA, Y.; NAGAHAMA, Y.; SAKUMA, Y. Neurons synthesizing gonadotropin-releasing hormone mRNA subtypes have multiple developmental origins in the medaka. Journal of Comparative Neurology, v. 401, p. 217-226, 1998.

PARHAR, I. S. Cell migration and evolutionary significance of $\mathrm{GnRH}$ subtypes. Progress in Brain Research, v. 141, p. 3-17, 2002.

PARHAR, I. S.; OGAWA, S.; SAKUMA, Y. Three GnRH receptor types in lasercaptured single cells of the cichlid pituitary display cellular and functional heterogeneity. Proceedings of the National Academy of Sciences, v. 102, p. 2204-2209, 2005.

PARK, D.; EISTHEN, H. L. Gonadotropin releasing hormone $(\mathrm{GnRH})$ modulates odorant responses in the peripheral olfactory system of axolotls. Journal of Neurophysiology, v. 90, p. 731-738, 2003.

PATIÑO, R.; SULLIVAN, C. V. Ovarian follicle growth, maturation, and ovulation in teleost fish. Fish Physiology and Biochemistry, v. 26, p. 57-70, 2002.

PAWSON, A. J.; MORGAN, K.; MAUDSLEY, S. R.; MILLAR, R. P. Type II gonadotrophin-releasing hormone $(\mathrm{GnRH}-\mathrm{II})$ in reproductive biology. Reproduction, v. 126, p. 271-278, 2003.

PEREIRA FILHO, H. P.; ANDRADE, D. R.; TONINI, W. C. T.; VIDAL JUNIOR, M. V. Biologia reprodutiva de fêmeas de lambari-prata, Astyanax scabripinnis, 1842 (Characidae; Tetragonopterinae, Teleostei) em condições de cativeiro. Ciência Animal Brasileira, v. 12, p. 626-634, 2011. 
PINELLI, C.; FIORENTINO, M.; D'ANIELLO, B.; TANAKA, S.; RASTOGI, R.K.; Immunohistochemical demonstration of $\mathrm{FSH}$ and $\mathrm{LH}$ in the pituitary of the developing frog, Rana esculenta. General and Comparative Endocrinology, v. 104, p. 189-196, 1996.

PODHOREC, P.; KOURIL, J. Induction of final oocyte maturation in Cyprinidae fish by hypothalamic factors: a review. Veterinarni Medicina, v.54, n. 3, p. 97-110, 2009.

PORTO FORESTI, F.; OLIVEIRA, C.; FORESTI, F.; CASTILHO ALMEIDA, R. B. Cultivo do Lambari: Uma espécie de pequeno porte e grandes possibilidades. Panorama da Aquicultura, v. 11, p. 15-19, 2001.

POWELL, J. F. F.; STRANDEN, E. M.; CAROLSFELD, J.; BORELLA, M. I.; GAZOLA, R.; FISCHER, H. W.; PARK, M; CRAIG, G. A.; WARBY, M. C.; RIVIER, E. J.; VAL SELLA, V. M.; SHERWOOD, M. N. Primary structure of three forms of gonadotropin-releasing hormone $(\mathrm{GnRH})$ from the pacu brain. Regulatory Peptides, v. 68, p.189-195, 1997.

QUAGIO GRASSIOTTO, I.; GRIER, H.; MAZZONI, T.S.; NÓBREGA, R.H.; AMORIM, J.P.A. Activity of the ovarian germinal epithelium in the freshwater catfish, Pimelodus maculatus (Teleostei: Ostariophysi: Siluriformes): germline cysts, follicle formation and oocyte development. Journal of Morphology, v. 272, p. 1290-1306, 2011.

QUÉRAT, B. Molecular evolution of the glycoprotein hormones in vertebrates. In: Davey, K. G.; Peter, R. E.; Tobe, S. S. (Eds). Perspective in Comparative Endocrinology. Ottawa: National Research Council of Canada. 1994, p.27-35.

REBERS, F. E.; HASSING, G. A.; ZANDBERGEN, M. A.; GOOS, H. J.; SCHULZ, R. W. Regulation of steady-state luteinizing hormone messenger ribonucleic acid levels, de novo synthesis, and release by sex steroids in primary pituitary cell cultures of male African catfish, Clarias gariepinus. Biology of Reproduction, v. 62 , p. 864-87, 2000.

RISSMAN, E. F.; ALONES, V. E.; CRAIG-VEIT, C. B.; MILLAM, J. R. Distribution of chicken-II gonadotropin-releasing hormone in mammalian brain. Journal of Comparative Neurology, v.357, n. 4, p. 524-531, 1995. 
RIZZO, E.; BAZZOLI, N. Follicular atresia in curimatá-pioa Prochilodus affinis Reinhardt, 1874 (Pisces, Characiformes). Revista Brasileira de Biologia, v. 55, p. 697-703, 1995.

ROBISON, R.R., WHITE, R.B., ILLING, N., TROSKIE, B.E., MORLEY, M., MILLAR, R.P. FERNALD, R.D. Gonadotropin-releasing hormone receptor in the teleost Haplochromis burtoni: structure, location, and function. Endocrinology, v. 142, p. 1737-1743, 2001.

ROCH, G. J.; BUSBY, E. R.; SHERWOOD, N. M. Evolution of GnRH: Diving deeper. General Comparative and Endocrinology, v. 171, p. 1-16, 2011.

ROCH, G. J.; BUSBY, E. R.; SHERWOOD, N. M. GnRH receptors and peptides: Skating backward. General and Comparative Endocrinology, v. 209, p.118-134, 2014.

RODRIGUES, A. M.; CAMPOS, E. C.; SANTOS, R. A.;MANDELLI JUNIOR, J.; CAMARA, J. J. C. Tipo de desova e fecundidade do tambiú Astyanax bimaculatus Linnaeus, 1758 (Pisces, Characiformes, Characidae), na represa de lbitinga, Estado de São Paulo, Brasil. Brazilian Journal of Veterinarian Research and Animal Science, 20, 309-315, 1992.

ROMAGOSA, E.; PAIVA, P.; GODINHO, H. M. Pattern of oocyte diameter frequency distribution in females of the pacu, Piaractus mesopotamicus (Holmberg, 1887) (= Colossoma mteri, Berg, 1895), induced to spawn. Aquaculture, v. 86, p. 105-110, 1990.

ROSEMBLUM, P. M.; GOOS, H. J. T.; PETER, R. E. Regional distribution and in vitro secretion of salmon and chicken-II gonadotropin-releasing hormones from the brain and pituitary of juvenile and adult goldfish, Carassius auratus. General and Comparative Endocrinology, v.93, p. 369-379, 1994.

SAIDAPUR, S. K.. Follicular atresia in the ovaries of nonmammalian vertebrates. International Reviews in Cytology, v. 54, p. 225-244, 1978.

SAMBROOK, J.; RUSSEL, D. W. Molecular Cloning - A Laboratory Manual. 3. ed. New York: Cold Spring Harbor Laboratory Press, 2001. 
SAMPATH KUMAR, R.; IJIRI, S.; TRANT, J. M. Molecular biology of channel catfish gonadotropin receptors: Cloning of a functional luteinizing hormone receptor and preovulatory induction of gene expression. Biology of Reproduction, v. 64, p. 1010-1018, 2000.

SCHNEIDER, J. S.; RISSMAN, E. F. Gonadotropin-releasing hormone II: a multipurpose neuropeptide. Integrative and Comparative Biology, v. 48, n. 5, p. 588595, 2008.

SCHRECK, C. B. Stress and fish reproduction: The roles of allostasis and hormesis. General and Comparative Endocrinology, v. 165, p. 549-556, 2010.

SCHULZ, R. W.; MENTING, S.; BOGERD, J.; FRANCA, L. R.; VILELA, D. A. R.; GODINHO, H. P. Sertoli cell proliferation in the adult testis: evidence from two fish species belonging to different orders. Biology of Reproduction, v. 73, p. 891898, 2005.

SCHULZ, R. W.; FRANÇA, L. R.; LAREYRE, J.; LEGAC, F.; CHIARINI GARCIA, H.; NOBREGA, R. H.; MIURA, T. Spermatogenesis in fish. General and Comparative Endocrinology, v. 165, p. 390-411, 2010.

SELMAN, S.; WALLACE, R. A.; SARKA, A.; QI, X. Stages of oocyte development in the zebrafish, Brachydanio rerio. Journal of Morphology, v. 218, p.203-224, 1993.

SERVILI, A.; LETHIMONIER, C.; JACQUES LAREYRE, J.; LOPEZ OLMEDA, J. F.; SANCHEZ VAZQUEZ, F. J.; KAH, O.; MUNOZ CUETO, J. A. The highly conserved gonadotropin-releasing hormone-2 form acts as a melatonin-releasing factor in the pineal of a teleost fish, the European sea bass Dicentrarchus labrax. Endocrinology, v. 151, n. 5, p. 2265-2275, 2010.

SHERWOOD, N. M.; SOWERS, S. A.; MARSHAKLI, D. R.; FRASERLL, B. A.; BROWNSTEINN, M. J. Primary Structure of Gonadotropin-releasing Hormone from Lamprey Brain. The Journal of Biological Chemistry, v. 261, n. 11, p. 48124819, 1986.

SHERWOOD, N. M.; DOROSHOV, S.; LANCES, V. Gonadotropin-Releasing Hormone (GnRH) in Bony Fish that Are Phylogenetically Ancient: Reedfish (Calamoichthys calabaricus), Sturgeon (Acipenser transmonfanus), and Alligator 
Gar (Lepisosteus spatula). General and Comparative Endocrinology, v. 84, p. 44-57, 1991.

SHERWOOD, N. M.; LOVEJOY, D. A.; COE, I. R. Origin of mammalian gonadotropin-releasing hormones. Endocrinology Reviews, v. 14, n. 2, p. 241254, 1993.

SILVER, R.; RAMOS, C. L.; SILVERMAN, A. J. Sexual behavior triggers the appearance of non-neuronal cells containing gonadotropin- releasing hormone-like immunoreactivity. Journal of Neuroendocrinology, v. 4, n. 2, p. 207-210, 1992.

SILVER, M.R.; KAWAUCHI, H.; NOZAKI, M.; SOWER, S.A. Cloning and analysis of the lamprey GnRH-III cDNA from eight species of lamprey representing the three families of Petromyzoniformes. General and Comparative Endocrinology, v. 139, p. 85-94, 2004.

SMALL, B. C. Effect of dietary cortisol administration on growth and reproductive success of channel catfish. Journal of Fish Biology, v. 64, p. 589-596, 2004.

SMITH, J. J.; KURAKU, S.; HOLT, C.; SAUKA SPENGLER, T.; JIANG, N.; CAMPBELL, M. S.; YANDELL, M. D.; MANOUSAKI, T.; MEYER, A.; BLOOM, O. E.; MORGAN, J. R.; BUXBAUM, J. D.; SACHIDANANDAM, R.; SIMS, C.; GARRUSS, A.S., COOK, M., KRUMLAUF, R., WIEDEMANN, L.M., SOWER, S.A., DECATUR, W. A.; HALL, J. A.; AMEMIYA, C. T.; SAHA, N. R.; BUCKLEY, K. M.; RAST, J. P.; DAS, S.; HIRANO, M.; MCCURLEY, N.; GUO, P.; ROHNER, N.; TABIN, C. J.; PICCINELLI, P.; ELGAR, G.; RUFFIER, M.; AKEN, B. L.; SEARLE, S. M.; MUFFATO, M.; PIGNATELLI, M.; HERRERO, J.; JONES, M.; BROWN, C. T.; CHUNG DAVIDSON, Y. W.; NANLOHY, K. G.; LIBANTS, S. V.; YEH, C. Y.; MCCAULEY, D. W.; LANGELAND, J. A.; PANCER, Z.; FRITZSCH, B.; DE JONG, P. J.; ZHU, B.; FULTON, L. L.; THEISING, B.; FLICEK, P.; BRONNER, M. E.; WARREN, W. C.; CLIFTON, S. W.; WILSON, R. K.; LI, W. Sequencing of the sea lamprey (Petromyzon marinus) genome provides insights into vertebrate evolution. Nature Genetic, v. 45, p. 415-421, 2013.

SOGA, T.; OGAWA, S.; MILLAR, R. P.; SAKUMA, Y.; PARHAR, I. S. Localization of the three $\mathrm{GnRH}$ types and $\mathrm{GnRH}$ receptors in the brain of a cichlid fish: insights into their neuroendocrine and neuromodulator functions. Journal Comparative Neurology, v. 487, p. 28-41, 2005.

SOMARAKIS, S.; GANIAS, E. K.; TSERPES, E. G.; KOUTSIKOPOULOS, C. Ovarian allometry and the use of the gonosomatic índex: a case study in the 
Mediterranean sardine, Sardina pilchardus. Marine Biology, v. 146, p. 181-189, 2004.

SOMOZA, M. G.; STEFANO, A.; D’ERANO, L. J.; CANOSA, F. L.; FRIDMAN, O. Immonoreactive $\mathrm{GnRH}$ suggesting a third form of $\mathrm{GnRH}$ in addition to cllGnRH and $\mathrm{sGnRH}$ in the brain and pituitary gland of Prochilodus lineatus (Characiformes). General and Compative Endocrinology, v. 94, p. 42-54, 1994.

STEVEN, C.; LEHNEN, N.; KIGHT, K.; IJIRI, S.; KLENKE, U., HARRIS, W. A.; ZOHAR, Y. Molecular characterization of the GnRH system in zebrafish (Danio rerio): cloning of chicken $\mathrm{GnRH}-\mathrm{Il}$, adult brain expression patterns and pituitary content of salmon $\mathrm{GnRH}$ and chicken $\mathrm{GnRH}-\mathrm{II}$. General and Comparative Endocrinology, v. 133, p. 27-37, 2003.

STOCCO, D. M. StAR protein and the regulation of steroid hormone biosynthesis. Annual Review of Physiology, v. 63, p. 193-213, 2001.

SUZUKI, H. I.; BULLA, C. K.; AGOSTINHO, A. A.; GOMES, L. C. Estratégias reprodutivas de assembléias de peixes em reservatórios. In: RODRIGUES, L.; THOMAZ, S. M.; AGOSTINHO, A. A.; GOMES, L. C. (Eds.). Biocenose em reservatórios: padrões espaciais e temporais. São Carlos, Rima Editora, 2005, p. 223-236.

SWANSON, P.; DICKEY, J.T.; CAMPBELL, B. Biochemistry and physiology of fish gonadotropins. Fish Physiology and Biochemistry, v. 28, p. 53-59, 2003.

TARNCHALANUKIT, W. Induced spawning of catfish Clarias batrachus by water level regulation. In: IDLER, D. R.; CRIM, L. W.; WALSH, J. M. (Eds.). Reproductive Physiology of Fish, St. John's: Memorial University Press, 1987, p. 138.

THOMAS, P. Characteristics of membrane progestin receptor alpha (mPRa) and progesterone membrane receptor component 1 (PGMRC1) and their roles in mediating rapid progestin actions. Frontiers in Neuroendocrinology, v. 29, p. 292-312, 2008.

THOMAS, P. Rapid steroid hormone actions initiated at the cell surface and the receptors that mediate them with an emphasis on recent progress in fish models. General and Comparative Endocrinology, v. 175, p. 367-383, 2012. 
TOSTIVINT, H. Evolution of the gonadotropin-releasing hormone $(\mathrm{GnRH})$ gene family in relation to vertebrate tetraploidizations. General and Comparative Endocrinology, v. 170, p. 575-581, 2011.

TSAI, P. S.; ZHANG, L. The emergence and loss of gonadotropin releasing hormone in protostomes: orthology, phylogeny, structure, and function. Biology of Reproduction, v. 79, p. 798-805, 2008.

TSUTSUMI, M.; ZHOU, W.; MILLAR, R. P.; MELLON, P. L.; ROBERTS, J. L.; FLANAGAN, C. A.; DONG, K.; GILLO, B.; SEALFON, S. C. Cloning and functional expression of a mouse gonadotropin-releasing hormone receptor. Molecular Endocrinology, v. 6, p. 1163-1169, 1992.

TSUTSUMI, M.; LAWS, S. C.; SEALFON, S. C. Homologous up-regulation of gonadotropin-releasing hormone receptor inaT3-1 cells is associated with unchanged receptor messenger RNA (mRNA) levels and altered mRNA activity. Molecular Endocrinology, v. 7, p. 1625-1633, 1993.

TUBBS, C.; THOMAS, P. Functional characteristics of membrane progestin receptor alpha (mPRalpha) subtypes: a review with new data showing mPRalpha expression in seatrout sperm and its association with sperm motility. Steroids, v. 73, p. 935-941, 2008.

TUZIAK, S. M.; VOLKOFF, H. Gonadotrophin-releasing hormone in winter flounder (Pseudopleuronectes americanus): Molecular characterization, distribution and effects of fasting. General and Comparative Endocrinology, v. 184, p. 9-21, 2013.

UCHIDA H.; OGAWA S.; HARADA M.; MATUSHITA M.; IWATA M.; SAKUMA, Y.; PARHAR I.S. The olfatory organ modulates gonadotropina releasing homrone types and nest building behavior in the tilapia Oreochromis niloticus. Journal of Neurobiology, v. 65, p. 1-11, 2005.

UEMURA, T.; YANAGISAWA, T.; SHIRASU, K.; MATSUYAMA, A.; MINAGUCHI, $\mathrm{H}$. Mechanism involved in the pituitary desensitization induced by gonadotropinreleasing hormone agonists. American Journal of Obstetrics \& Gynecology, v.167, p. 283-291, 1992.

VAZZOLER, A. E. A. M. Biologia da reprodução de peixes teleósteos: teoria e prática. Eduem: Maringá, 1996, p.169. 
VICKERS, E. D.; LABERGE, F.; ADAMS, B. A.; HARA, T. J.; SHERWOOD, N. M. Cloning and localization of three forms of gonadotropin-releasing hormone, including the novel whitefish form, in a salmonid, Coregonus clupeaformis. Biology of Reproduction, v.70, p. 1136-1146, 2004.

VOLKOFF, H.; PETER, R. E. Actions of two forms of gonadotropinreleasing hormone and a $\mathrm{GnRH}$ antagonist on spawning behavior of the goldfish Carassius auratus. General and Comparative Endocrinology, v. 116, p. 347-355, 1999.

VOLKOFF, H.; CANOSA, L. F.; UNNIAPPAN, S.; CERDA-REVERTER, J. M.; BERNIER, N. J.; KELLY, S. P.; PETER, R. E. Neuropeptides and the control of food intake in fish. General and Comparative Endocrinology, v. 142, p. 3-19, 2005.

XIA, W.; SMITH, O.; ZMORA, N.; XU, S.; ZOHAR, Y. Comprehensive Analysis of GnRH2 Neuronal Projections in Zebrafish. Scientific Reports, v. 4, n. 3676, p. 1$11,2014$.

ZANIBONI FILHO, E.; WEINGART, M. Técnica de indução da reprodução de peixes migradores. Revista Brasileira de Reprodução Animal, v. 31, p. 367-373, 2007.

ZHANG, W.; DELAY R. J. Gonadotropin releasing hormone modulates voltage activated sodium current and odor responses in Necturus maculosus sensory neurons. Journal of. Neuroscience Research, v. 85, p. 1656-166, 2007.

ZHANG, S.; ZHANG, Y.; CHEN, E.; WU, Y.; GE, W.; ZHANG, L.; ZHANG. W. Aromatase (Cyp19a1b) in the Pituitary Is Dynamically Involved in the Upregulation of Ihb But Not fshb in the Vitellogenic Female Ricefield Eel Monopterus albus. Endocrinology, v.155, n. 11, p.4531-4541, 2014.

ZOHAR Y.; GOREN A.; FRIDKIN M.; ELHANATI E.; KOCH Y. Degradation of gonadotropin-releasing hormones in the gilthead seabream Sparus aurata II. Cleavage of native salmon $\mathrm{GnRH}$, mammalian LHRH and their analogs in the pituitary, kidney and liver. General and Comparative Endocrinology, v. 79, p. 306-319, 1990.

YARON, Z.; GUR, G.; MELAMED, P.; ROSENFELD, H.; ELIZUR, A.; LEVAVI SIVAN, B. Regulation of fish gonadotropins. International Review of Cytology, v. 225, p. 131-185, 2003. 
YOKOYAMA, S.; OSHIMA, Y.; TOKITA, J.; SUDA, M.; SHINOZUKA, T.; NAKAMURA, M. Androgen receptor of the frog Rana rugosa: molecular cloning and its characterization. Journal of Experimental Zoology Part A: Ecological Genetics and Physiology, v. 311, p. 796-812, 2009.

YOUNG, G.; KUSAKABE, M.; NAKAMURA, I.; LOKMAN, P. M.; GOETZ, F. W. Gonadal steroidogenesis in teleost fish. In: Melamed, P.; Sherwood, N. (Eds.). Hormones and Their Receptors in Fish Reproduction. NewJersey: World Scientific Publishing Company, 2005, p.155-223.

YU, W. H.; KARANTH, S.; WALCZEWSKA, A.; SOWER, S. A.; MCCANN, S. M. A hypothalamic follicle-stimulating hormone-releasing decapeptide in the rat. Proceedings of the National Academy of Sciences, v. 94, p. 9499-9503, 1997.

YUEH, W. S.; CHANG, C. F. 17,20, 21-Trihydroxy-4-pregnen-3-one and 17,20dihydroxy-4-pregnen-3-one stimulated spermiation in protandrous black porgy, Acanthopagrus schlegeli. Fish Physiology and Biochemistry, v. 17, p. 187-193, 1997.

WALLACE, R. A.; SELMAN, K. Cellular and dynamic aspects of oocyte growth in teleosts. American Zoology, v. 21, p. 325-343, 1981.

WALLACE, R. A.; SELMAN, K. Ultrastructural aspects of oogenesis and oocyte growth in fish and amphibians. Journal of Electron Microscopy Technique, v. 16, p. 175-201, 1990.

WALLIS, M. Episodic evolution of protein hormones in mammals. Journal of Molecular Evolution, v. 53, p. 10-18, 2001.

WANG, Y.; GE, W. Cloning of epidermal growth factor (EGF) and EGF receptor from the zebrafish ovary: evidence for EGF as a potential paracrine factor from the oocyte to regulate activin/follistatin system in the follicle cells. Biology of Reproduction. v. 71, p. 749-760, 2004.

WESTRING, C. G.; ANDO, H.; KITAHASHI, T.; BHANDARI, R. K.; UEDA, H.; URANO, A.; DORES, R. M.; SHER, A. A.; DANIELSON, P. B. Seasonal changes in CRF-I and urotensin I transcript levels in Masu salmon: Correlation with cortisol secretion during spawning. General and Comparative Endocrinology, v. 155, p. 126-140, 2008. 
WHITE, R. B.; EISEN, J. A.; KASTEN, T. L.; FERNALD, R. D. Second gene for gonadotropin-releasing hormone in humans. Proceedings of the National Academy of Sciences, v. 95, p. 305-309, 1998.

WHITE, R. B.; FERNALD, R. D. Ontogeny of gonadotropin-releasing hormone $(\mathrm{GnRH})$ gene expression reveals a distinct origin for $\mathrm{GnRH}$ containing neurons in the midbrain. General and Comparative Endocrinology, v. 112, p. 322-329, 1998.

WOYNAROVICH, E.; HORVÁTH, L. A propagação de peixes de aguas tropicais: manual de extensão. Brasilia: FAO/CODEVASF/CNPq, 1983. 


\section{ANEXO I}

EF-1a (Elongation Factor 1- alpha) - Fragmento clonado e blast da sequência

CTCCAGCTATTTAGGTGAACTATAGATACTCAAGCTATGCATCCAACGCGTTGGGAGCTCTCCC ATATGGYCGACCTGCAGGCGGCCGCGAATTCACTAGTGATTCGCTGACTTCCTTGGTGATTTC CTCAAAACGAGCCTGGCTGTATGGGGRCTCGGTGGAATCCATCTTGTTGACTCCAACGATAAG CTGCTTCACTCCCAATCGAATTCCCGCGGCCGCCATGGCGGCCGGGAGCATGCGACGTCGG GCCCAATTCGCCCTATAGTGAGTCGTATTACAATTCACTGGCCGTCGTTTTACAACGTCGTGAC TGGGAAAACCCTGGCGTTACCCAACTTAATCGCCTTGCAGCACATCCCCCTTTCGCCAGCTGG CGTAATAGCGAAGAGGCCCGCACCGATCGCCCTTCCCAACAGTTGCGCAKYYTGAATGGCGA ATGGACGCGCCCTGTAGCGGCGCATTAAGCGCGGCGGGTGTGGTGGTTACGCGCAGCGTGA CCGCTACACTTGCCAGCGCCCTAGCGCCCGCTCCTTTCGCTTTCTTCCCTTCCTTTCTCGCCA CGTTCGCCGGCTTTCCCCGTCAAGCTCTAAATCGGGGGCTCCCTTTAGGGTTCCGATTTAGTG CTTTACGGCACCTCGACCCCAAAAAACTTGATTAGGGTGATGGTTCACGTAGTGGGCCATCGC CCTGATAGACGGTTTTTCGCCCTTTGACGTTGGAGTCCACGTTCTTTAATAGTGGACTCTTGTT CCAACTGGAACACACTCAACCCTATCTCGGTCTATTCTTTTGATTTATAGGATTTGCCGATTTCG GCCTATGGTAAAAATGAGCTGATTACAAAAATTACGCGAATTTACAATATACGCTACATTCTGAT GCGTATTTCTCTACGCATCTGKGCGATTCMCACCGCATCAGKGCACTTC

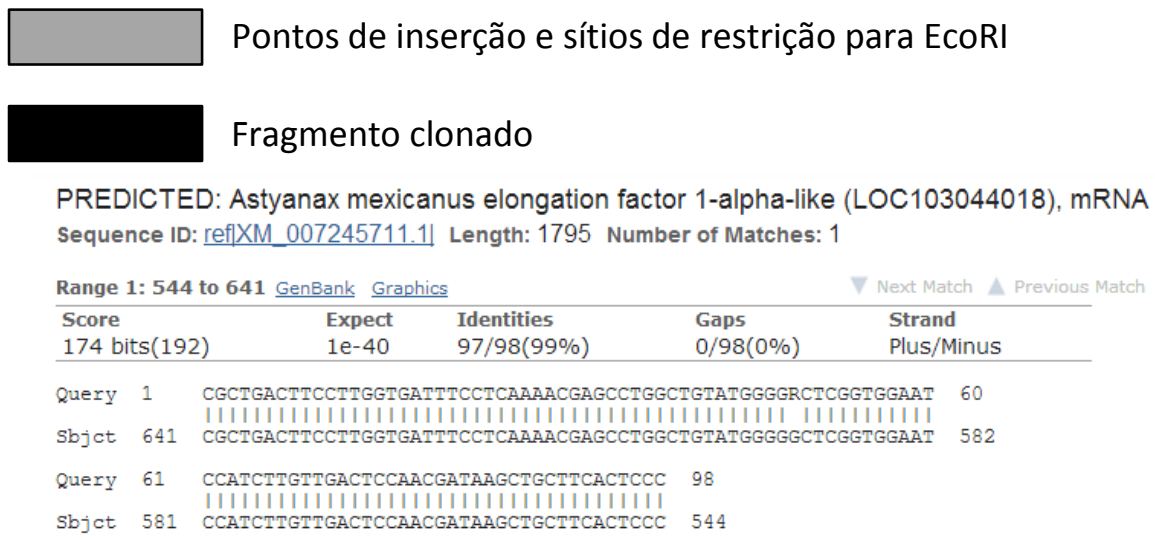

FSH $\beta$ (Hormônio Folículo Estimulante ) - Fragmento clonado e blast da sequência

AATATAGGGCGATTGGGCCCGACGTCGCATGCTCCCGGCCGCCATGGCGGCCGCGGGAATT CGATTGTCYTGAKGATTCTGCTGCTGCCTGCTCTGCTGAGGGGAGCACCMGGATGTAAGGCC AGCTGCCGCCTTACCAACATCTCCATCACTGTGGAGAGCGAGGAATGCAATCACTAGTGAATT CSCGGCCGCCTGCAGGTCGACCATATGGGAGAGCTCCCAACGCGTTGGATGCATAGCTTGAG TATTCTATAGTGTCACCTAAATAGCTTGGCGTAATCATGGTCATAGCTGTTTCCTGTGTGAAATT GTTATCCGCTCACAATTCCACACAACATACGAGCCGGAAGCATAAAGTGTAAAGCCTGGGGTG CCTAATGAGTGAGCTAACTCACATTAATTGCGTTGCGCTCACTGCCCGCTTTCCAGTCGGGAA ACCTGTCGTGCCAGCTGCATTAATGAATCGGCCAACGCGCGGGGAGAGGCGGTTTGCGTATT GGGCGCTCTTCCGCTTCCTCGCTCACTGACTCGCTGCGCTCGGTCGTTCGGCTGCGGCGAGC GGTATCAGCTCACTCAAAGGCGGTAATACGGTTATCCACAGAATCACGGGATAACGCAGAAAG AACATGTGAGCAAAAGGCCAGCAAAGGCCAGGAACCGTAAAAAGGCSCGTTGCTGGCGTTTT CCATAGGCTCCSCCCCCCTGACGAGCATCAMAAAATCGACGCTCAAGTCAGAGGTGGCGAAA CCCGACAGGACTWTAAAGAWACCAGSGTTTCCCTGGAAGCTCCCTCGKGSSCTYYYCTTGTTC CGACCCTGCCGCTTACCGATACTGTCCSCCTTTCYCCTTCCGAGSGKGGCGCTTYTCAWAGCT 
CACGCCKGAGWTYCAGTTCGGTKAGGTCGTCGTCCAGCTGGGCTGGGTGMCGAACCCCGMT CAGCGAACSCTGGCCTWTCGTMCWCGCTTGATCACTGTGGAACGACTTAGCCATGTCACAGC CATG

Pontos de inserção e sítios de restrição para EcoRI

Fragmento clonado

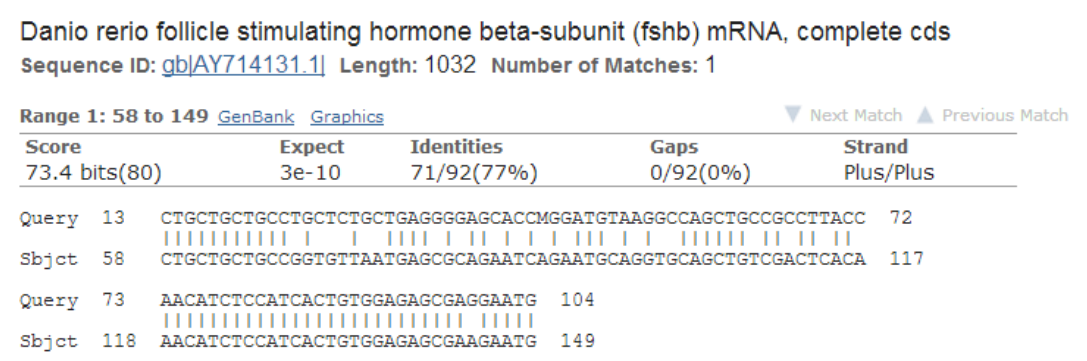

LHß (Hormônio Luteinizante) - Fragmento clonado e blast da sequência

CACCAGCCTTTTAGGTGAACTATAGAATACTCAGCTATGCATCCAACGCGTTGGGAGCTCTCC CATATGGYCGACCTGCAGGCGGCCGCGAATTCACTAGTGATTTGCTGATAGATGGTGGAGAAT GGGCTCTTGTACACCGGATCCTTGGTGAGGCAATGTCCACTGCAAATAGTGGTCTGAAACACT AGGCATTTTGGGCAGCAATCGAATTCCCGCGGCCGCCATGGCGGCCGGGAGCATGCGACGT CGGGCCCAATTCGCCCTATAGTGAGTCGTATTACAATTCACTGGCCGTCGTTTTACAACGTCGT GACTGGGAAAACCCTGGCGTTACCCAACTTAATCGCCTTGCAGCACATCCCCCTTTCGCCAGC TGGCGTAATAGCGAAGAGGCCCGCACCGATCGCCCTTCCCAACAGTTGCKYWKYYTGAATGG CGAATGGACGCGCCCTGTAGCGGCGCATTAAGCGCGGCGGGTGTGGTGGTTACGCGCAGCG TGACCGCTACACTTGCCAGCGCCCTAGCGCCCGCTCCTTTCGCTTTCTTCCCTTCCTTTCTCG CCACGTTCGCCGGCTTTCCCCGTCAAGCTCTAAATCGGGGGCTCCCTTTAGGGTTCCGATTTA GTGCTTTACGGCACCTCGACCCCAAAAAACTTGATTAGGGTGATGGTTCACGTAGTGGGCCAT CGCCCTGATAGACGGTTTTCGCCCTTTGACGTTGGAGTCCACGTTCTTTAATAGTGGACTCTTG TTCCAACTGGACACACTCAACCCTATCTCGGTCTATTCTTTTGATTATAAGGATTTGCCGATTCG GCTATTGGTAAAAATGAGCTGATTTAACAAAAATTTACGCGATTTTACAAATATACGCTACATGC TGATGCGATTTCTCTACGCATYTGTGCGATTCMACCGCATCA

Pontos de inserção e sítios de restrição para EcoRI

Fragmento clonado

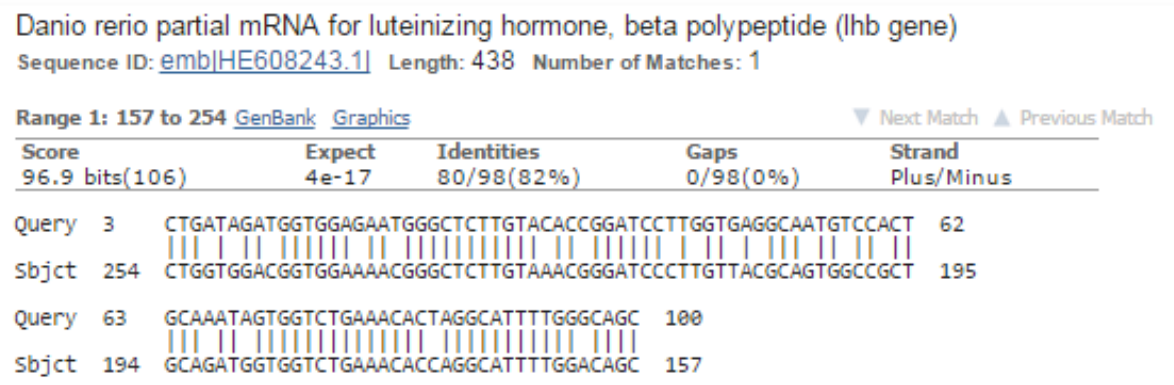


GnRH2 (Hormônio liberador de Gonadotropinas 2) - Fragmento clonado e blast da sequência

TCTATAGGGCGATTGGGCCGACGTCGCATGCTCCCGGCCGCCATGGCGGCCGCGGGAATTC GATTAGGATGCTCTTCAGGATGTTGGTTCTCAGAGGTCTCAGATAACTGCATTCTCCTGCTCCA CACAGTTTAATCTCTTCTGACACCTCTGGTGAACTGTAGGGGTCGATCAATCACTAGTGAATTC GCGGCCGCCTGCAGGTCGACCATATGGGAGAGCTCCCAACGCGTTGGATGCATAGCTTGAGT ATTCTATAGTGTCACCTAAATAGCTTGGCGTAATCATGGTCATAGCTGTTTCCTGTGTGAAATTG TTATCCGCTCACAATTCCACACAACATACGAGCCGGAAGCATAAAGTGTAAAGCCTGGGGTGC CTAATGAGTGAGCTAACTCACATTAATTGCGTTGCGCTCACTGCCCGCTTTCCAGTCGGGAAA CCTGTCGTGCCAGCTGCATTAATGAATCGGCCAACGCGCGGGGAGAGGCGGTTTGCGTATTG GGCGCTCTTCCGCTTCCTCGCTCACTGACTCGCTGCGCTCGGTCGTTCGGCTGCGGCGAGCG GTATCAGCTCACTCAAAGGCGGTAATACGGTTATCCACAGAATCACGGGATAACGCAGAAAGA ACATGTGAGCAAAAGGCCAGCAAAAGGCCAGGAACCGTAAAAAGGCGCGTTGCTGGCGTTTT CCATAGGCTCCGCCCCCCTGACGAGCATCACAAAATCGACGCTCAAGTCAGAGGTGGCGAAA CCCGACAGGACTWTAAGAWACCAGGCGTTCCCCTGGAAGCTCCCTCGKGCGCYYTCCTTGTT CCGACCTKGCSSTTACCGGATACTKCCGCTTYYCCCTCCGGAAGSGKGGGSCTTYTCTWAGCT CMCSCTKAAGWTCTCCAGTCCGGGKAAGGTCGTCGCCTCAGCTTGCTTGTKACRACTCCGGT CAGCGACGTKGCCTTACGTAACWTCGCTTGATCACTGTAAACGACTTAGCCMTGACGATCMTG

Pontos de inserção e sítios de restrição para EcoRI

Fragmento clonado

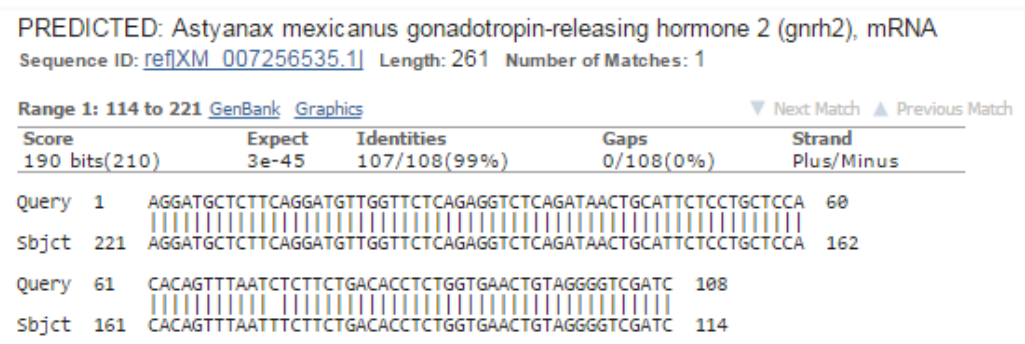

GnRH3 (Hormônio liberador de Gonadotropinas 2) - Fragmento clonado e blast da sequência

GWMCTATAGGGCGATTGGGCCGACGTCGCATGCTCCCGGCCGCCATGGCGGCCGCGGGAA TTCGATTCCCTGAACGTTGCTTCCAGTTCCCCCACGCTCCTCTTTCCTCCAGGCATCCATCCGT ACGACCAGTGCTGACACACACCCACCTCCACCACACACGCCAGCACCAGCAGCCCGACCACC ACCCGCCAGTTCCACTCCACAAATCACTAGTGAATTCGCGGCCGCCTGCAGGTCGACCATATG GGAGAGCTCCCAACGCGTTGGATGCATAGCTTGAGTATTCTATAGTGTCACCTAAATAGCTTG GCGTAATCATGGTCATAGCTGTTTCCTGTGTGAAATTGTTATCCGCTCACAATTCCACACAACA TACGAGCCGGAAGCATAAAGTGTAAAGCCTGGGGTGCCTAATGAGTGAGCTAACTCACATTAA TTGCGTTGCGCTCACTGCCCGCTTTCCAGTCGGGAAACCTGTCGTGCCAGCTGCATTAATGAA TCGGCCAACGCGCGGGGAGAGGCGGTTTGCGTATTGGGCGCTCTTCCGCTTCCTCGCTCACT GACTCGCTGCGCTCGGTCGTTCGGCTGCGGCGAGCGGTATCAGCTCACTCAAAGGCGGTAAT 
ACGGTTATCCACAGAATCAGGGATAACGCAGGAAAGAACATGTGAGCAAAAGGCCAGCAAAG GCCAGGAACCGTAAAAAGGCSCGTTGCTGGCGTTTTCCATAGGCTCCGCCCCCCTGACGAGC ATCMCAAAAATCGACSCTCAAGTCAGAGGTGGSCGAACCCGACAGGACTWTAAGATACCAGC GTTTCCCCTGGAAGCTCCCTCGKGSGCTYYCTTGTTCGACCCTGCGCTTACCGGATACCTTGT CGCCTTTCTCCCTCCGGGAGCGTGGSCTTTYCATAGCTMAGCKGAGWWTCYCAGTCGGGKAA GTCGTCGTTCCAGCTGCTGTGACGATCCCCKGTCAGCCGAACGTGGCCTATC

Pontos de inserção e sítios de restrição para EcoRI

Fragmento clonado

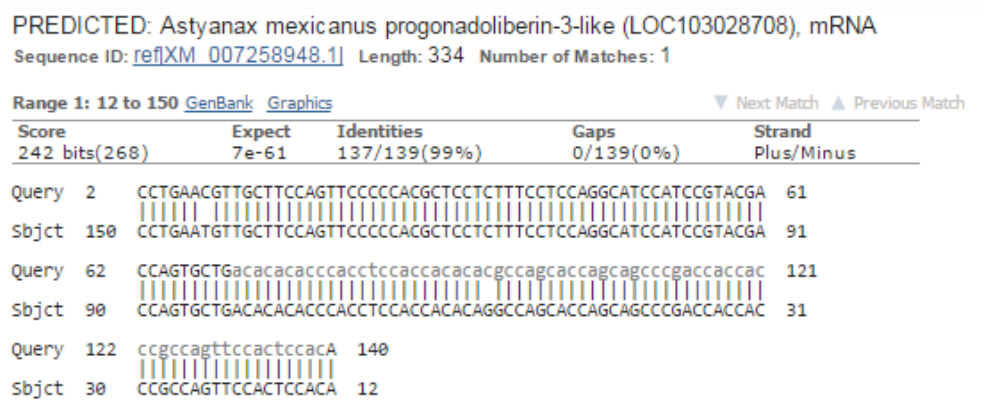

